DIANA BUCHNER DE OLIVEIRA SANCHEZ

\title{
DESEMPENHO REOLÓGICO E ENTÁLPICO DA MASSA DE PÃO COM AMIDO RESISTENTE DE MILHO E TRANSGLUTAMINASE
}


DIANA BUCHNER DE OLIVEIRA SANCHEZ

\section{DESEMPENHO REOLÓGICO E ENTÁLPICO DA MASSA DE PÃO COM AMIDO RESISTENTE DE MILHO E TRANSGLUTAMINASE}

Dissertação apresentada à Escola Politécnica da Universidade de São Paulo para obtenção do Título de Mestre em Engenharia Química 


\section{DESEMPENHO REOLÓGICO E ENTÁLPICO DA MASSA DE PÃO COM AMIDO RESISTENTE DE MILHO E TRANSGLUTAMINASE}

Dissertação apresentada à Escola Politécnica da Universidade de São Paulo para obtenção do Título de Mestre em Engenharia Química

Área de Concentração:

Engenharia de Química

Orientadora: Prof $\stackrel{a}{\text {. Titular Carmen C. }}$ Tadini 


\section{FICHA CATALOGRÁFICA}

\section{Sanchez, Diana Buchner de Oliveira}

Desempenho reológico e entálpico da massa de pão com amido resistente de milho e transglutaminase / D.B.O. Sanchez . -- São Paulo, 2009.

$81 \mathrm{p}$.

Dissertação (Mestrado) - Escola Politécnica da Universidade de São Paulo. Departamento de Engenharia Química.

1. Pão 2. Amido 3. Enzimas 4. Alimentos funcionais 4. Reologia 5. Análise térmica I. Universidade de São Paulo. Escola Politécnica. Departamento de Engenharia Química II. t. 
Aos meus pais Regina e Cesar, meus irmãos Frederico e Alexandre, e meu querido marido Leandro. 


\section{AGRADECIMENTOS}

À minha orientadora Prof ${ }^{a}$ Carmen Tadini, pela oportunidade, dedicação e exemplo.

Ao projeto CYTED (106AC0301 PANXTODOS) pela oportunidade de realizar o estágio na Argentina, especialmente ao Dr. Alberto E. León, Dr. Pablo D. Ribotta (Universidad Nacional de Cordoba, CEPROCOR) e Dra. Maria Cecília Puppo (CIDCA, Universidad Nacional de La Plata) pela atenção e ensinamentos transmitidos.

À Capes e FAPESP pelas bolsas concedidas.

À Danisco e ao Moinho Pacífico pelas amostras doadas.

Ao Moinho Anaconda, pela disponibilização do farinógrafo, em especial à Eng. Bruna Nascimento.

Ao IDPC por disponibilizar os equipamentos de seu laboratório, e oferecer todo suporte necessário. Aos técnicos Felício e Helena que me acolheram com tanto carinho.

Ao amigo Prof. José Roberto Cardoso, pelos conselhos e incentivo à pesquisa.

Às amigas do laboratório Ana Cristina Souza, Helena Aguiar, Janaína Mainardi, Nathalia Aliberti e Otília Carvalho pelos divertidos momentos compartilhados, festas organizadas e lanchinhos diários. Aos colegas Viviane Kechichian, Carola Gutierrez, Fabrício Resende, Cynthia Ditchfield, Tatiana Tribess, Prof. Dr. Jorge Gut e aos funcionários Ivan Nunes, Vanessa Duarte e Maísa Coelho por todo o apoio.

Às estagiárias Juliana Kichise e Gaelle Chretien com as quais eu tanto aprendi. À Analía Gomez pela companhia na padaria e os deliciosos pães argentinos. À Raquel Bianchi pela contribuição na parte experimental.

À amiga Regiane Borella pelos meses de árduo estudo e ajuda mútua.

A toda minha família que sempre esteve ao meu lado.

Em especial ao meu esposo e grande amigo Leandro por acreditar e ser meu maior incentivador em todos os momentos.

A todos que direta ou indiretamente contribuíram na execução desse trabalho. 


\section{RESUMO}

O objetivo desse trabalho foi estudar a influência da substituição parcial da farinha de trigo ( $F T)$ por amido resistente de milho (ARM) e da adição da enzima transglutaminase (TG) sobre o desempenho reológico e entálpico da massa de pão. O ARM foi adicionado como uma alternativa de aumentar a ingestão de fibra alimentar (FA), enquanto que a TG foi adicionada como forma de suprir a diluição do glúten, catalisando as ligações. Foram realizadas análise de textura da massa (extensão uniaxial, biaxial e Texture Profile Analysis - TPA), análise térmica de calorimetria exploratória diferencial (DSC) e reológica (reofermentógrafo). De acordo com um planejamento experimental estrela com três pontos centrais e quatro axiais as análises foram conduzidas em cinco níveis de substituição da farinha de trigo (FT) pelo amido resistente de milho (ARM): 1,5 \%; 3,5 \%; 8,5\%; 13,5\%; 15,5\% (base $100 \%$ mistura) e cinco níveis de adição de enzima transglutaminase (TG): 0,03 \%; $0,05 \% ; 0,10 \% ; 0,15 \% ; 0,17 \%$. As mesmas análises foram realizadas em massa produzida com farinha de trigo (controle), sem adição de ARM e TG.

A substituição de FT por ARM influenciou mais os parâmetros de textura do que a adição de TG. A resistência à extensão atingiu um valor $32 \%$ maior que o controle com a substituição de $8,5 \%$ de ARM e adição de $0,12 \%$ de TG. Nos ensaios realizados no DSC foram identificados três picos endotérmicos, sendo eles: fusão da água, gelatinização do amido do trigo $\left(60^{\circ} \mathrm{C}\right)$ e gelatinização do ARM $\left(115^{\circ} \mathrm{C}\right)$. A altura máxima de desenvolvimento da massa $(\mathrm{Hm})$, medida no reofermentógrafo, foi influenciada significativamente, diminuindo com o aumento da adição de ARM. A absorção de água aumentou conforme a adição de fibras, porém até $11 \%$ de substituição por ARM pode ser considerado igual ao controle. No intervalo estudado, a TG não contribuiu positivamente no desempenho da massa e, portanto, baseado nos resultados obtidos, a mistura com substituição de FT por ARM até 8,5\% não influenciará significativamente os seus parâmetros reológicos e de textura, podendo ser utilizada para manufatura de pão com maior teor de fibras.

Palavras-chave: Pão de forma. Amido resistente de milho. Enzima transglutaminase. Alimentos funcionais. Fibra alimentar. Textura. Reologia. Análise térmica. 


\begin{abstract}
The objective of this work was to study the partial substitution of wheat flour (WF) to maize resistant starch (MRS) and the addition of transglutaminase enzyme (TG) on the rheological and enthalpy properties of pan bread dough. The MRS was added as an alternative to increase the fiber ingestion while TG was added to supply the gluten dilution, catalyzing the bonds. Texture analyses (uniaxial extension, biaxial extension and Texture Profile Analysis - TPA), thermal analysis on Differential Scanning Calorimetric (DSC) and rheological tests (rheofermentometer) were carried out in pan bread dough produced with five levels of wheat flour substitution from maize resistant starch: $1.5 \%$; $3.5 \%$; $8.5 \%$; $13.5 \%$; $15.5 \%$ (basis on $100 \%$ of mixture) and five addition levels of transglutaminase (TG): $0.03 \% ; 0.05 \% ; 0.10 \%$; $0.15 \% ; 0.17 \%$ according to a composite design $\left(2^{2}\right)$ with three central and four star points. The same tests were conducted in pan bread dough without added MRS and TG and considered as control. The substitution of WF from MRS has more influenced the textural parameters than the addition of TG. The extension strength achieved a value $32 \%$ higher than control with the substitution of $8.5 \%$ of MRS and $0.12 \%$ of TG. During the DSC tests, it has been found three endothermic peaks: fusion of water, gelatinization of wheat starch $\left(60^{\circ} \mathrm{C}\right)$ and gelatinization of MRS $\left(115^{\circ} \mathrm{C}\right)$. The maximum dough height $(\mathrm{Hm})$, obtained from rheofermentometer curves, was significantly influenced, decreasing with the increase the addition of MRS. The absorption of water increased with the fibers addition, however up to $11 \%$ of substitution of MRS, it could be considered equal to the control. TG did not contribute positively on the dough performance, at studied interval, and therefore mixture with substitution of WF by MRS up to $8.5 \%$ will not significantly influence their rheological and texture parameters and can be used to manufacture pan bread with high fiber content.
\end{abstract}

Key-words: Pan bread. Maize resistance starch. Transglutaminase enzyme. Functional food. Dietetic fiber. Texture. Rheology. Thermal analysis. 


\section{LISTA DE FIGURAS}

Figura 3-1. Esquema do preparo das massas para os testes de extensão uniaxial e Texture Profile Analysis (TPA).

Figura 3-2. Molde de acrílico com $8 \mathrm{~mm}$ de espessura usado para moldar as massas para o teste de TPA e extensão biaxial (Dough Inflation System).

Figura 3-3. Molde de blocos para preparação das tiras de massa para o teste de extensão uniaxial.

Figura 3-4. Masseira Argental. 35

Figura 3-5. Amostras moldadas em discos 35

Figura 3-6. Esquema do preparo das massas para o teste de extensão biaxial (Dough Inflation System).

Figura 3-7. Micro-farinógrafo Brabender utilizado no preparo das massas para análise de DSC.

Figura 3-8. (1) Seladora de cápsulas de alumínio para análise de DSC. (2) Cápsulas de alumínio.

Figura 3-9. Teste de extensão uniaxial da massa de pão realizado no texturômetro TA-xT2i com acessório A/KIE Kieffer Dough \& Gluten extensibility rig.

Figura 3-10. Curva típica obtida do teste de extensão uniaxial de massa de pão (F:

resistência à extensão, L: extensibilidade na ruptura e A: energia aplicada à massa até a ruptura).

Figura 3-11. Texturômetro TA-xT2i com acessório Dobraszczyk/Roberts (D/R) para o teste de extensão biaxial (Dough Inflation System).

Figura 3-12. Curva típica obtida do teste de extensão biaxial de massa de pão: a tenacidade (P) obtida diretamente da curva e a extensibilidade (L), obtida indiretamente pelo tempo do teste, a uma dada velocidade constante.

Figura 3-13. Ensaio TPA na massa de pão, no Texturômetro TA-xT2i equipado com probe $\mathrm{P} / 50$.

Figura 3-14. Curva típica obtida do teste TPA e os respectivos parâmetros de textura calculados, sendo a área 1 correspondente a $1^{\underline{a}}$ compressão e a área 2 , à $2^{\underline{a}}$ compressão.43 Figura 3-15. Equipamento de calorimetria exploratória diferencial (DSC)

Figura 3-16. Curva do programa de temperatura aplicado nas massas, durante o ensaio do DSC.

Figura 3-17. Curva típica do DSC com indicação da temperatura onset ( $\left.T_{\text {onset }}\right)$, entalpia $(\Delta H)$ calculado pelo software Universal Analysis 2000 (TA Instruments)...................................45

Figura 3-18. Reofermentógrafo F3 CHOPIN ......................................................... 46 
Figura 3-19. Curva típica de desenvolvimento da massa, obtida no reofermentógrafo

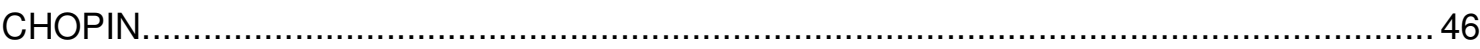

Figura 3-20. Curva típica de retenção gasosa, obtida no reofermentógrafo CHOPIN. ….....47

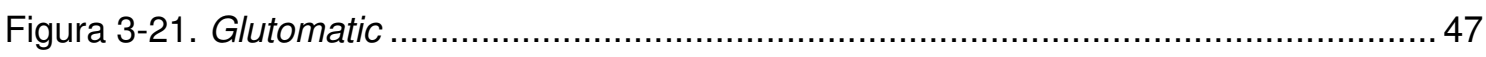

Figura 3-22. Glúten úmido e seco no Glutork ....................................................... 48

Figura 3-23. Exemplo de curva obtida no farinógrafo, indicando os parâmetros obtidos...... 48

Figura 4-1. Efeitos principais causados pela substituição por amido resistente de milho (ARM) e adição da enzima transglutaminase (TG) nos parâmetros resistência à extensão $(F)$, extensibilidade na ruptura $(L)$ e energia aplicada à massa até a ruptura $(A)$, obtidos do teste de extensão uniaxial da massa de pão.

Figura 4-2. Superfície de resposta para a resistência à extensão $(F)$ obtida do teste de extensão uniaxial, conforme substituição de farinha de trigo (FT) por amido resistente de milho (ARM) e adição da enzima transglutaminase (TG).

Figura 4-3. Efeitos principais causados pela substituição de farinha de trigo (FT) por amido resistente de milho (ARM) e adição da enzima transglutaminase (TG) nos parâmetros energia de deformação da massa $(\mathrm{W}), P / L$, tenacidade $(P)$ e extensibilidade $(L)$ obtidos do teste de extensão biaxial da massa de pão.

Figura 4-4. Efeitos principais causados pela substituição de amido resistente de milho (ARM) e adição da enzima transglutaminase (TG) nos parâmetros dureza, coesividade, adesividade, elasticidade e resiliência obtidos do teste de TPA (Texture Profile Analysis) da massa de pão.

Figura 4-5. Termogramas de suspensões de amido resistente de milho (ARM) com diferentes quantidades de água, indicando o evento de fusão da água.

Figura 4-6. Termogramas de suspensões de farinha de trigo (FT) com diferentes quantidades de água, indicando o evento da gelatinização do amido.

Figura 4-7. Termogramas de suspensão do amido resistente de milho (ARM) com diferentes quantidades de água, indicando o evento da gelatinização do ARM. 60

Figura 4-8. Efeitos principais causados pela substituição de farinha de trigo (FT) por amido resistente de milho (ARM) e adição da enzima transglutaminase (TG) na entalpia $(\Delta H)$ de gelatinização do ARM e na $T_{\text {onset. }}$

Figura 4-9. Altura de desenvolvimento da massa $(\mathrm{Hm})$ determinada no reofermentógrafo em função do nível de substituição de farinha de trigo (FT) por amido resistente de milho (ARM).

Figura 4-10. Efeitos principais causados pela substituição por amido resistente de milho (ARM) e adição da enzima transglutaminase (TG) nos parâmetros glúten úmido, glúten seco e índice de glúten. 
Figura 4-11. Conteúdo de glúten úmido determinado pelo Glutomatic em função da substituição de farinha de trigo (FT) por amido resistente de milho (ARM). 68

Figura 4-12. Valores médios de absorção de água determinada pelo farinógrafo Brabender para diferentes substituições de farinha de trigo (FT) por amido resistente de milho (ARM).70 Figura 4-13. Efeitos principais causado pela substituição de FT por ARM e adição de TG no teor de umidade e cinzas das massas. 71

Figura 4-14. Superfície de resposta para o conteúdo de cinzas conforme substituição de farinha de trigo (FT) por amido resistente de milho (ARM) e adição da enzima transglutaminase (TG) 


\section{LISTA DE TABELAS}

Tabela 2-1. Principais compostos funcionais investigados pela ciência, de acordo com a Sociedade Brasileira de Alimentos Funcionais. 18

Tabela 2-2. Constituintes de fibra alimentar de acordo com a classificação da American

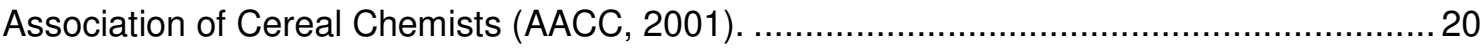

Tabela 2-3. Critérios quantitativos para alegações relacionadas ao conteúdo de fibra alimentar (FA) em alimentos prontos para o consumo, segundo legislação brasileira.......... 20

Tabela 2-4. Ingredientes utilizados na formulação de pães de forma..................................21

Tabela 2-5. Composição da farinha de trigo 22

Tabela 3-1. Quantidades de amido resistente de milho (ARM) e enzima transglutaminase (TG) utilizadas na formulação de massas de acordo com planejamento experimental estrela de segunda ordem $\left(2^{2}\right)$, com três pontos centrais e quatro axiais. .................................... 31 Tabela 3-2. Laudo da farinha M. Extra - PT (MOINHO PACÍFICO, 2008). .......................... 32 Tabela 4-1. Valores médios da resistência à extensão $(F)$, extensibilidade na ruptura $(L)$ e energia aplicada à massa até a ruptura $(A)$ obtidos pelo teste de extensão uniaxial das massas de pão em função da porcentagem de substituição de farinha de trigo (FT) por amido resistente de milho (ARM).

Tabela 4-2. Valores médios da resistência à extensão $(F)$, determinada pelo teste uniaxial das massas de pão em função da porcentagem de adição de enzima transglutaminase (TG).

Tabela 4-3. Valores médios da tenacidade $(P)$, extensibilidade $(L)$ e da razão $P / L$ obtidos do teste biaxial das massas de pão em função da porcentagem de substituição de farinha de trigo (FT) por amido resistente de milho (ARM). .54

Tabela 4-4. Valores médios da energia de deformação da massa ( $W$ ) obtidos do teste biaxial das massas de pão em função da porcentagem de adição da enzima transglutaminase (TG).

Tabela 4-5. Parâmetros obtidos da TPA (Texture Profile Analysis) em função da substituição de farinha de trigo (FT) por amido resistente de milho (ARM) e da adição da transglutaminase (TG) nas massas. 56

Tabela 4-6. Valores médios de dureza e resiliência obtidos no teste de TPA de acordo com a substituição de farinha de trigo (FT) por amido resistente de milho (ARM). .56

Tabela 4-7. Temperatura onset ( $\left.T_{\text {onset }}\right)$, entalpia de fusão $\left(\Delta_{\text {fus }} H\right)$, fração de água congelável ( $F W$ e fração de água não-congelável (UFW), calculados do pico de entalpia de fusão da água, nas massas produzidas com diferentes quantidades de amido resistente de milho (ARM) e da adição da transglutaminase (TG). 
Tabela 4-8. Temperatura onset $\left(T_{\text {onset }}\right)$, entalpia de gelatinização $(\Delta H)$, calculados do pico de entalpia de gelatinização do amido de trigo, nas massas produzidas com diferentes quantidades de amido resistente de milho (ARM) e da adição da transglutaminase (TG)...61 Tabela 4-9. Temperatura onset ( $\left.T_{\text {onset }}\right)$ e entalpia de gelatinização $(\Delta H)$ calculados do pico de entalpia de gelatinização do ARM, nas massas produzidas com diferentes quantidades de amido resistente de milho (ARM) e da adição da transglutaminase (TG).

Tabela 4-10. Valores obtidos das curvas do reofermentógrafo, conforme substituição de farinha de trigo (FT) por amido resistente de milho (ARM) e adição da enzima transglutaminase (TG).

Tabela 4-11. Altura de desenvolvimento da massa $(H m)$ obtida das curvas de desenvolvimento da massa conforme substituição de farinha de trigo (FT) por amido resistente de milho (ARM)

Tabela 4-12. Conteúdos de glúten úmido, glúten seco e índice de glúten das misturas conforme substituição de farinha de trigo (FT) por amido resistente de milho (ARM) e adição

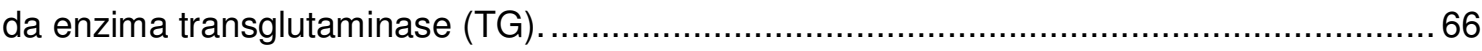

Tabela 4-13. Valores médios dos conteúdos de glúten úmido e seco ..............................67 Tabela 4-14. Valores médios dos parâmetros obtidos das massas analisadas em farinógrafo conforme substituição de farinha de trigo (FT) por amido resistente de milho (ARM)........... 69 Tabela 4-15. Valores médios em base úmida dos teores de umidade e cinzas das massas analisadas conforme substituição de farinha de trigo (FT) por amido resistente de milho (ARM) e adição da enzima transglutaminase (TG).

Tabela 4-16. Valores médios obtidos para a umidade das massas e cinzas conforme substituição de farinha de trigo (FT) por amido resistente de milho (ARM) . ........................ 72 Tabela 4-17. Valores médios obtidos para as cinzas ............................................... 72 


\section{LISTA DE ABREVIATURAS E SIGLAS}

AACC American Association of Cereal Chemists

ANOVA Análise de Variância

AOAC Association of Official Agricultural Chemists

AR Amido resistente

ARM Amido resistente de milho

CNPq Conselho Nacional de Desenvolvimento Científico e Tecnológico

CYTED Ciencia y Tecnología para el Desarrollo

DMS Diferença mínima significativa

DSC Calorimetria Exploratória Diferencial (do inglês Differential Scanning Calorimetry)

FA Fibra alimentar

FT Farinha de trigo

GRAS Generally Recognized as Safe

HSD Honestly Significant Difference

ICC International Association for Cereal Science and Technology

IDPC Instituto do Desenvolvimento de Panificação e Confeitaria

IG Índice glicêmico

MRS Maize Resistant Starch

PROPAN Programa de Apoio à Panificação

SMS Stable Micro Systems

TG Enzima transglutaminase

TPA Texture Profile Analysis

U.F. Unidades Farinográficas

WF Wheat Flour 


\section{LISTA DE SÍMBOLOS}

A Energia aplicada à massa até a ruptura (N.mm)

A1 Área do volume de gás retido $(\mathrm{mL})$

A2 Área do volume de gás perdido $(\mathrm{mL})$

$C_{r}$ Coeficiente de retenção do gás (\%)

$F$ Resistência à extensão $(\mathrm{mN})$

FW Fração de água congelável (\%)

$\mathrm{Hm}$ Altura máxima de desenvolvimento da massa $(\mathrm{mm})$

$H^{\prime} m$ Altura relativa à pressão máxima $(\mathrm{mm})$

ITM Índice de tolerância à mistura (U.F.)

$L$ Extensibilidade $(\mathrm{mm})$

$P$ Tenacidade $\left(\mathrm{mm} \mathrm{H}_{2} \mathrm{O}\right)$

$t_{d}$ Tempo de desenvolvimento da massa (min)

$T_{\text {onset }}$ Temperatura de onset $\left({ }^{\circ} \mathrm{C}\right)$

Tx Tempo em que a massa começa a perder $\mathrm{CO}_{2}(\mathrm{~min})$

T1 Tempo correspondente à altura máxima de desenvolvimento ( $\min$ )

T'1 Tempo correspondente à pressão máxima (min)

UFW Fração de água não-congelável (\%)

$W$ Energia de deformação da massa (J)

$\Delta H$ Entalpia ( $/ \mathrm{g}$ massa seca)

$\Delta_{\text {fus }} H$ Entalpia de fusão $(\mathrm{J} / \mathrm{g})$

$\lambda$ Calor latente de fusão da água $(\mathrm{J} / \mathrm{g})$ 


\section{SUMÁRIO}

\begin{tabular}{|c|c|c|}
\hline 1 & INTRODUÇÃO & \\
\hline 2 & REVISÃO DA LITERATURA & \\
\hline 2.1 & Panificação & 1 \\
\hline 2.1.1 & Panorama & 4 \\
\hline 2.1 .2 & Pão & \\
\hline 2.2 & Alimentos Funcionais & 1 \\
\hline 2.2.1 & Alimentos para ingestão controlada ou com restrição de nutrientes & 1 \\
\hline 2.2 .2 & Fibra Alimentar (FA) & 1 \\
\hline 2.3 & Formulação da massa do pão de forma & 2 \\
\hline 2.3.1 & Farinha de trigo $(\mathrm{FT})$ & 2 \\
\hline 2.3.2 & Água, sal e fermento & 2 \\
\hline 2.3 .3 & Coadjuvantes tecnológicos & 2 \\
\hline 2.3.4 & Amido resistente de milho (ARM) & 2 \\
\hline 2.3.5 & Enzima transglutaminase na panificação & 2 \\
\hline 2.4 & Produção da massa do Pão de forma & 2 \\
\hline 2.5 & Métodos de ensaio utilizados & \\
\hline 3 & MATERIAIS E MÉTODOS & 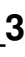 \\
\hline 3.1 & Materiais & \\
\hline 3.2 & Métodos & 3 \\
\hline 3.2.1 & Preparo das massas para as análises de extensão uniaxial, biaxial e TPA (do inglês & \\
\hline Textur & Profile Analysis) & \\
\hline 3.2 .2 & Preparo das massas para as análises de Calorimetria Exploratória Diferencial (DSC) & 3 \\
\hline 3.2.3 & Preparo das massas para as análises no reofermentógrafo & 3 \\
\hline 3.2 .4 & Teste de extensão uniaxial & 3 \\
\hline 3.2.5 & Teste de extensão biaxial (Dough Inflation System) & 3 \\
\hline 3.2.6 & Texture Profile Analysis (TPA) & 4 \\
\hline 3.2.7 & Análises de Calorimetria Exploratória Diferencial (DSC) & 4 \\
\hline 3.2.8 & Reofermentógrafo & 4 \\
\hline 3.2 .9 & Conteúdo de glúten úmido e seco & 4 \\
\hline 3.2 .10 & Farinografia & 4 \\
\hline 3.2.11 & Conteúdo de água (umidade) & \\
\hline 3.2.12 & Cinzas_ & 4 \\
\hline 3.3 & Análise dos resultados & 4 \\
\hline 4 & RESULTADOS E DISCUSSÕES & 5 \\
\hline 4.1 & Parâmetros de textura obtidos no teste de extensão uniaxial & \\
\hline 4.2 & Parâmetros de textura obtidos no teste biaxial & \\
\hline 4.3 & Parâmetros de textura obtidos das curvas de TPA (Texture Profile Analysis) & \\
\hline 4.4 & Análises de Calorimetria Exploratória Diferencial (DSC) & \\
\hline 4.5 & Reofermentógrafo & \\
\hline 4.6 & Glúten úmido e seco & \\
\hline 4.7 & Farinografia & \\
\hline 4.8 & Umidade e cinzas das massas & \\
\hline 5 & CONCLUSÕES & \\
\hline \multicolumn{2}{|c|}{ REFERÊNCIAS BIBLIOGRÁFICAS } & \\
\hline
\end{tabular}




\section{INTRODUÇÃO}

Uma crescente demanda por alimentos saudáveis e que tragam benefícios para a saúde do consumidor ocorre no mercado. Dentro deste contexto, os alimentos funcionais contendo fibra alimentar ( $F A)$ vem sendo foco de estudos relacionados à redução nos níveis de colesterol do plasma sanguíneo e da resposta glicêmica, ao aumento da velocidade do trânsito intestinal, sequestro e aumento da excreção de substâncias tóxicas, aumento da excreção de ácidos biliares e estrógenos, alívio da constipação, melhora da qualidade da microflora intestinal e redução da incidência de câncer de cólon (SGARBIERI; PACHECO, 1999; WASZCZYNSKYJ et al., 2001).

Em contrapartida, Menezes; Giuntini e Lajolo (2001) demonstraram que a ingestão da FA pela população brasileira, entre as décadas de 70 e 90, baseada em seis regiões metropolitanas, diminuiu de $19,3 \mathrm{~g} / \mathrm{d}$ na década de 70 para 16,0 g/d na década de 80 e para $12,4 \mathrm{~g} / \mathrm{d}$ na década de 90 . Dentre as regiões metropolitanas pesquisadas, as que apresentaram maior redução no consumo de FA foram a região de São Paulo, no estado de São Paulo e a de Porto Alegre, no estado do Rio Grande do Sul. Estas apresentaram redução de $50 \%$ entre as décadas de 70 e 90, destacando que a população da região de São Paulo reduziu o consumo diário de FA de 18,8 para 9,3 (cerca de $50 \%$ ) e a região de Porto Alegre, de 17,8 para 8,5 (52\%).

O número de estudos relacionados à tecnologia de produção de pão como alimento funcional com maior teor de amido resistente (AR) (HUNG; MORITA, 2004; HUNG; YAMAMORI; MORITA, 2005; MORITA et al., 2002) cresce de modo concorrente ao número de trabalhos que correlacionam o uso do AR como fonte de FA e o seu potencial uso em alimentos funcionais (AKERBERG; LILJEBERG; BJÖRCK, 1998; GOÑI; GARCÍA-ALONSO; SAURA-CALIXTO, 1997; QUEIROZMONICl et al., 2005; ROSIN; LAJOLO; MENEZES, 2002; YAMADA et al., 2005).

A substituição de uma fração de farinha de trigo $(\mathrm{FT})$ por FA em produtos de panificação pode ser utilizado como apelo de "fonte de fibras", quando a quantidade de FA é superior a $3 \mathrm{~g} / 100 \mathrm{~g}$ de alimento ou "alto teor de fibras" quando sua quantidade for superior a $6 \mathrm{~g} / 100 \mathrm{~g}$ de alimento (BRASIL, 1998b). Tecnologicamente, a substituição de $\mathrm{FT}$ por $\mathrm{AR}$ afeta a qualidade do pão, pela diluição do glúten (MICHNIEWICZ; BILIADERIS; BUSHUK, 1991). Entretanto, qualquer que seja o tipo 
da fibra adicionada em pães, é necessário ajustar os parâmetros da massa para que apresente alta qualidade do produto final, e obter produtos aceitáveis pelos consumidores.

Em panificação, as proteínas do glúten são as maiores responsáveis pela formação da estrutura do pão, exercendo papel fundamental. Associadas com os lipídios são responsáveis pela coesão da massa e das propriedades viscoelásticas (AÑÓN et al., 2004). Relatos na literatura sobre o uso de enzimas tais como, amilases, proteases e xylanases indicam efeitos positivos sobre a qualidade do pão (GUJRAL; ROSELL, 2004; HARADA et al., 2000; MOORE et al., 2006; ROSELL et al., 2003). A transglutaminase (TG) confere força à massa de pão, uma vez que atua por meio de diferentes mecanismos catalíticos e pode induzir a forma polimerizada de subunidades da glutenina e também transformar proteínas solúveis em insolúveis, melhorando sua funcionalidade (ROSELL et al., 2003). Quando ingredientes de panificação são substituídos ou reduzidos de sua formulação original, a adição de TG ajuda a manter ou aumentar o volume final do pão (MOTOKI; SEGURO, 1998).

Um estudo confrontando a qualidade tecnológica da substituição parcial da FT por ARM e o uso combinado da enzima TG será de grande auxílio no desenvolvimento de novos produtos de panificação, como alternativa de introdução de fibras na dieta do povo brasileiro.

Este trabalho faz parte do projeto 106PI0301- OBTENCIÓN DE PRODUCTOS DE PANIFICACIÓN PARA NECESIDADES ESPECÍFICAS, convênio CYTED CNPq, sob a coordenação do Prof. Alberto Edel León, da Universidade Nacional de Córdoba, Córdoba, Argentina, com a participação do Laboratório de Engenharia de Alimentos do Departamento de Engenharia Química da Escola Politécnica da Universidade de São Paulo.

O objetivo principal do projeto de pesquisa foi verificar a influência da substituição parcial de farinha de trigo (FT) por amido resistente de milho (ARM) e da adição da enzima transglutaminase sobre o desempenho de panificação de massas destinas à fabricação de pães, através de ensaios reológicos, de textura e entálpicos. 


\section{REVISÃO DA LITERATURA}

\subsection{Panificação}

\subsubsection{Panorama}

O segmento de panificação e confeitaria no Brasil está entre os seis maiores segmentos industriais do país e representa um faturamento anual ao redor de $\mathrm{R} \$ 39,61$ bilhões, sendo o setor composto por mais de 52 mil empresas e com mãode-obra direta empregada em torno de 600 mil pessoas (PROPAN, 2008). Atrelado ao mercado de panificação, cerca de $50 \%$ do total comercializado de farinha de trigo é destinado a este mercado (SINDIPAN, 2005).

Segundo PROPAN (2008), o consumo per capita de pães/ano no Brasil é de $29 \mathrm{~kg}$ (incluindo pães a base de outros cereais como aveia, milho, mandioca, etc.), enquanto que em outros países esse valor é bem mais alto, como por exemplo na Argentina $(73 \mathrm{~kg})$, no Chile $(93 \mathrm{~kg})$ e Uruguai $(51 \mathrm{~kg})$. Observa-se também uma grande diferença regional, pois, enquanto o sul e leste consomem $33 \mathrm{~kg}$ per capita, o nordeste consome $10 \mathrm{~kg}$. Fatores como hábito cultural, poder aquisitivo populacional, qualidade e variedade dos produtos influenciam esse baixo consumo.

\subsubsection{Pão}

O pão, em várias formas, é um dos alimentos básicos mais consumidos pela humanidade. Hoje, existem poucos países no mundo onde o pão não é fabricado, nem consumido. Geralmente é preparado com farinha de trigo, que após mistura e amassamento com água forma uma massa coesa e elástica ( ${ }^{1}$ BUSHUK, 1985; ${ }^{2}$ HOSENEY, 1985 apud STAUFFER, 1999).

O trigo é a base da alimentação da sociedade ocidental, desde o princípio dos tempos. Nos países onde o consumo de pão é bastante alto, os produtos obtidos do trigo fornecem aproximadamente a quinta parte do total de calorias de uma dieta (PALLARÉS; LÉON; ROSELL, 2007).

\footnotetext{
${ }^{1}$ BUSHUK, W. Flour proteins: Structure and functionality in dough and bread. Cereals Foods World, 30, 447-51, 1985.

2 HOSENEY, R. C. The Mixing phenomenon. Cereal Foods World, 30, 453-7, 1985.
} 
É possível a obtenção de farinha de outros cereais, mas a habilidade das proteínas presentes no trigo - o glúten - de formar uma massa elástica torna a farinha de trigo a principal para a produção de pães. Centeio e cevada também possuem glúten em sua composição, mas em menor quantidade do que ocorre normalmente no trigo (CAUVAIN, 1999).

As proteínas presentes nos grãos de trigo podem ser classificadas em dois grandes grupos: proteínas que formam o glúten (gliadina e glutenina), que são insolúveis e constituem de $(75-80) \%$ do total e as proteínas não formadoras do glúten (albuminas e globulinas), que são solúveis e constituem entre (20 - 25) \% (PALLARÉS; LÉON; ROSELL, 2007; STAUFFER, 1999).

O glúten é a principal proteína do trigo, responsável pela estrutura e, consequentemente, pela qualidade do pão. Quando em contato com água, e aplicada energia mecânica pelo amassamento, até mesmo com as mãos, forma-se a rede de glúten, que tem a habilidade de reter os gases formados durante a fermentação tornando a massa após assada, um alimento leve, macio e palatável (STAUFFER, 1999).

\subsection{Alimentos Funcionais}

Os alimentos funcionais são definidos como alimentos ou ingredientes que produzem efeitos metabólicos e/ou fisiológicos e/ou efeitos benéficos para a saúde, além de suas funções nutricionais convencionais, podendo ser consumidos sem supervisão médica. A eficácia e a segurança desses alimentos devem ser comprovadas por meio de estudos científicos (BRASIL, 1999; SALGADO, 2006).

A Sociedade Brasileira de Alimentos Funcionais (SALGADO, 2006) ressalta os principais componentes ativos estudados e as respectivas propriedades benéficas (ver Tabela 2-1), entre eles as fibras solúveis e insolúveis. 
Tabela 2-1. Principais compostos funcionais investigados pela ciência, de acordo com a Sociedade Brasileira de Alimentos Funcionais

\begin{tabular}{|c|c|c|}
\hline Componentes ativos & Propriedades benéficas & $\begin{array}{l}\text { Exemplos de alimentos } \\
\text { que contêm o componente }\end{array}$ \\
\hline Isoflavonas & $\begin{array}{l}\text { Ação estrogênica (reduz os efeitos da } \\
\text { menopausa) e anti-câncer }\end{array}$ & Soja e derivados \\
\hline Proteínas de soja & Redução dos níveis de colesterol & Soja e derivados \\
\hline $\begin{array}{l}\text { Ácidos graxos ômega-3 } \\
\text { (EPA e DHA) }\end{array}$ & $\begin{array}{l}\text { Redução do LDL-colesterol, ação } \\
\text { antiinflamatória. Indispensável para o } \\
\text { desenvolvimento do cérebro e da retina de } \\
\text { recém nascidos }\end{array}$ & $\begin{array}{l}\text { Peixes marinhos como } \\
\text { sardinha, salmão, atum, } \\
\text { anchova, arenque, etc. }\end{array}$ \\
\hline Ácido alfa-linolênico & $\begin{array}{l}\text { Estimula o sistema imunológico e possui } \\
\text { ação antiinflamatória }\end{array}$ & $\begin{array}{l}\text { Óleos de linhaça, colza e } \\
\text { soja, nozes e amêndoas }\end{array}$ \\
\hline Catequinas & $\begin{array}{l}\text { Reduzem a incidência de certos tipos de } \\
\text { câncer, reduzem o colesterol e estimulam o } \\
\text { sistema imunológico }\end{array}$ & $\begin{array}{l}\text { Chá verde, cerejas, amoras, } \\
\text { framboesas, mirtilo, uva } \\
\text { roxa, vinho tinto }\end{array}$ \\
\hline Licop & $\begin{array}{l}\text { Antioxidante, reduz níveis de colesterol e o } \\
\text { risco de certos tipos de câncer, como o de } \\
\text { próstata }\end{array}$ & $\begin{array}{l}\text { Tomate e derivados, goiaba } \\
\text { vermelha, pimentão } \\
\text { vermelho, melancia }\end{array}$ \\
\hline Luteína e Zeaxantina & $\begin{array}{l}\text { xidantes, protegem contra degeneração } \\
\text { ular }\end{array}$ & $\begin{array}{l}\text { Luteína: folhas verdes } \\
\text { Zeaxantina: pequi e milho }\end{array}$ \\
\hline Indóis e Isotiocianatos & $\begin{array}{l}\text { Indutores de enzimas protetoras contra o } \\
\text { câncer, principalmente o de mama }\end{array}$ & $\begin{array}{l}\text { Couve-flor, repolho, brócolis, } \\
\text { couve de Bruxelas, rabanete, } \\
\text { mostarda }\end{array}$ \\
\hline Flavonóides & $\begin{array}{l}\text { Atividade anti-câncer, vasodilatadora, } \\
\text { antiinflamatória e antioxidante }\end{array}$ & $\begin{array}{l}\text { Soja, frutas cítricas, tomate, } \\
\text { pimentão, alcachofra, cereja, } \\
\text { salsa, etc. }\end{array}$ \\
\hline $\begin{array}{l}\text { Fibras solúveis } \\
\text { insolúveis }\end{array}$ & $\begin{array}{l}\text { Reduz o risco de câncer de cólon, melhora o } \\
\text { funcionamento intestinal; fibras solúveis } \\
\text { podem ajudar no controle da glicemia e no } \\
\text { tratamento da obesidade, pois proporcionam } \\
\text { maior saciedade }\end{array}$ & $\begin{array}{l}\text { Cereais integrais como } \\
\text { aveia, centeio, cevada, farelo } \\
\text { de trigo, etc., leguminosas } \\
\text { como soja, feijão, ervilha, } \\
\text { etc., hortaliças com talos e } \\
\text { frutas com casca }\end{array}$ \\
\hline $\begin{array}{l}\text { Frutooligossacarídeos e } \\
\text { inulina }\end{array}$ & avorecendo o & $\begin{array}{l}\text { Extraídos de vegetais como } \\
\text { raiz de chicória e batata } \\
\text { yacon }\end{array}$ \\
\hline Sulfetos alílicos & $\begin{array}{l}\text { o colesterol, pressão sanguínea, } \\
\text { o sistema imunológico e reduzem } \\
\text { câncer gástrico }\end{array}$ & bola \\
\hline Ligninas & Inibição de tumores hormônio-dependentes & ça, noz moscada \\
\hline Tanino & ti-séptico, va & $\begin{array}{l}\text { Maçã, sorgo, manjericão, } \\
\text { manjerona, sálvia, uva, caju, } \\
\text { soja, etc. }\end{array}$ \\
\hline $\begin{array}{l}\text { Estanóis e esteróis } \\
\text { vegetais }\end{array}$ & $\begin{array}{lcccc}\text { Reduzem } & 0 & \text { risco de doenças } \\
\text { cardiovasculares }\end{array}$ & $\begin{array}{l}\text { Extraídos de óleos vegetais } \\
\text { como soja e de madeiras }\end{array}$ \\
\hline $\begin{array}{l}\text { Probióticos } \\
\text { Bifidobactérias } \\
\text { Lactobacilos }\end{array}$ & $\begin{array}{l}\text { Favorecem as funções gastro-intestinais, } \\
\text { reduzindo o risco de constipação e câncer de } \\
\text { cólon }\end{array}$ & $\begin{array}{l}\text { Leites fermentados, iogurtes } \\
\text { e outros produtos lácteos } \\
\text { fermentados }\end{array}$ \\
\hline
\end{tabular}

FONTE: SALGADO, 2006. 


\subsubsection{Alimentos para ingestão controlada ou com restrição de nutrientes}

Segundo a ANVISA (BRASIL, 1998a), alimentos para fins especiais são aqueles especialmente formulados ou processados, nos quais modificações são introduzidas nos nutrientes, adequados ao uso em dietas diferenciadas e ou opcionais, para necessidades de pessoas em condições metabólicas e fisiológicas específicas. Dentro deste grupo, ressaltam-se:

- Alimentos para dietas com restrição de nutrientes (carboidratos, proteínas, gorduras, etc.).

- Alimentos para ingestão controlada de nutrientes (para controle de peso, para praticantes de atividade física, para nutrição enteral, etc.).

- Alimentos para grupos populacionais específicos (lactantes, crianças, gestantes, idosos, etc.).

Dentre as alegações mais praticadas em produtos de panificação, encontramse alimentos para dietas com restrição de gorduras (0 \% gordura), alimentos com conteúdo energético reduzido (light), alimentos para dietas com restrição de proteínas (sem glúten) e alimentos para mulheres em fase de menopausa, com base de soja e linhaça, por exemplo, que auxiliam na redução dos sintomas da menopausa (BENASSI; WATANABE; LOBO, 2001; BROUNS, 2002; DHINGRA; JOOD, 2001; DOG, 2005; MOHAMED et al., 2006; SIVARAMAKRISHNAN; SENGE; CHATTOPADHYAY, 2004).

\subsubsection{Fibra Alimentar (FA)}

Segundo a American Association of Cereal Chemists (AACC, 2001): "Fibra alimentar é a parte comestível de plantas ou carboidratos análogos que são resistentes à digestão e absorção no intestino delgado humano com completa ou parcial fermentação no intestino grosso. Fibra alimentar inclui polissacarídeos, oligossacarídeos, lignina e substâncias associadas de plantas. A fibra alimentar promove efeitos fisiológicos benéficos incluindo laxação e/ou atenuação do nível de colesterol no sangue e/ou atenuação nos níveis de glicose no sangue".

A partir da classificação apresentada na definição de FA pela AACC (2001), os constituintes estão divididos como apresentado na Tabela 2-2. 
Tabela 2-2. Constituintes de fibra alimentar de acordo com a classificação da American Association of Cereal Chemists (AACC, 2001).

\begin{tabular}{|c|c|c|}
\hline & Tipo & Sub-tipo \\
\hline \multirow{8}{*}{$\begin{array}{l}\text { Polissacarídeos não-amidos } \\
\text { oligossacarídeos resistentes }\end{array}$} & Celulose & \multirow{8}{*}{$\begin{array}{l}\text { - } \\
\text { Arabinoxilanos } \\
\text { Arabinogalactanos } \\
\text { Inulina } \\
\text { Oligofrutanos } \\
\text { - } \\
\text { - } \\
- \\
-\end{array}$} \\
\hline & Hemicelulose & \\
\hline & Polifrutoses & \\
\hline & romitutuses & \\
\hline & Galacto-oligossacarídeos & \\
\hline & Gomas & \\
\hline & Mucilagens & \\
\hline & Pectinas & \\
\hline \multirow{5}{*}{ Carboidratos análogos } & & $\begin{array}{l}\text { Maltodextrinas resistentes } \\
\text { (de milho e outras fontes) }\end{array}$ \\
\hline & Dextrınas ındigerıveıs & Dextrinas resistentes de \\
\hline & & Polidextrose \\
\hline & $\begin{array}{l}\text { Componentes de carbolaratos } \\
\text { sintéticos }\end{array}$ & $\begin{array}{l}\text { Metil Celulose } \\
\text { Hidroxinronil metil celulose }\end{array}$ \\
\hline & Amidos indigeríveis (resistentes) & - \\
\hline Lignina & - & - \\
\hline \multirow{6}{*}{$\begin{array}{l}\text { Substâncias associadas ao } \\
\text { complexo de polissacarídeos } \\
\text { não-amidos e lignina em plantas }\end{array}$} & Ceras & - \\
\hline & Ftato & - \\
\hline & Cutina & - \\
\hline & Saponinas & - \\
\hline & Suberina & - \\
\hline & Taninos & - \\
\hline
\end{tabular}

FONTE: AACC, 2001.

Segundo a legislação brasileira, alimentos considerados como fonte de FA ou com alto teor de FA são definidos conforme a Tabela 2-3.

Tabela 2-3. Critérios quantitativos para alegações relacionadas ao conteúdo de fibra alimentar (FA) em alimentos prontos para o consumo, segundo legislação brasileira.

\begin{tabular}{ccc}
\hline Alegação & & $\begin{array}{c}\text { Quantidades de FA no produto pronto } \\
\text { para consumo }\end{array}$ \\
\hline Fonte de FA & Alimento sólido & Mínimo de $3 \mathrm{~g} / 100 \mathrm{~g}$ \\
& Alimento líquido & Mínimo de $1,5 \mathrm{~g} / 100 \mathrm{~mL}$ \\
Alto Teor de FA & Alimento sólido & Mínimo de $6 \mathrm{~g} / 100 \mathrm{~g}$ \\
& Alimento líquido & Mínimo de $3 \mathrm{~g} / 100 \mathrm{~mL}$ \\
\hline
\end{tabular}

FONTE: BRASIL, 1998b

Os alimentos contendo fibras trazem benefícios como redução do tempo de retenção do bolo fecal no intestino grosso, reduzindo o tempo de contato do órgão com substâncias cancerígenas e consequentemente reduzindo o índice de câncer colorretal (WASZCZYNSKYJ et al., 2001). 
O efeito das fibras pode ser mecânico (aumento do peso do bolo fecal e diminuição do tempo de retenção dentro do intestino) ou fisiológico (formação de ligações de ácidos e sais biliares e produção de ácidos graxos de cadeia curta).

\subsection{Formulação da massa do pão de forma}

Os ingredientes básicos para a maioria dos pães são farinha de trigo, água, fermento e sal. Pode-se também adicionar outros ingredientes como gordura vegetal, manteiga, açúcar, ovos, e coadjuvantes tecnológicos (a-amilase, emulsificantes e oxidantes). A Tabela 2-4 apresenta uma formulação típica para produção de pão de forma.

Tabela 2-4. Ingredientes utilizados na formulação de pães de forma

\begin{tabular}{|c|c|}
\hline Ingredientes & $\%^{1}$ \\
\hline $\begin{array}{l}\text { Farinha de trigo } \\
\text { Água } \\
\text { Sal } \\
\text { Gordura } \\
\text { Fermento biológico prensado } \\
\text { Açúcar } \\
\text { Coadjuvantes tecnológicos (melhorador) }\end{array}$ & $\begin{array}{c}100 \\
56-60 \\
2,0 \\
2,0-6,0 \\
4,5 \\
3,0-8,0 \\
2,0\end{array}$ \\
\hline
\end{tabular}

\subsubsection{Farinha de trigo (FT)}

A farinha de trigo é o principal ingrediente na indústria de panificação e a tecnologia empregada no seu beneficiamento determina sua qualidade e preço, e como consequência, a qualidade e o preço final do produto.

A composição da farinha depende da variedade do trigo e das condições de cultivo. $\mathrm{O}$ trigo é comercialmente dividido em quatro grandes classes: duro, mole, branco e "durum". Os trigos duros geralmente possuem cor escura e alto teor protéico, adequados para panificação; já os brancos são mais claros e possuem menor teor de proteína, adequado para bolos e tortas. O trigo mole possui baixo conteúdo protéico e é adequado para fabricação de biscoito e certos tipos de pães, como o sírio; o trigo "durum" é o que possui maior conteúdo protéico e é adequado 
para produção de massas alimentícias (LEONHARDT, 1999). Em média, a composição varia conforme a Tabela 2-5.

Tabela 2-5. Composição da farinha de trigo

\begin{tabular}{lc}
\hline & $\%$ \\
\hline Proteínas & $7,5-15,0$ \\
Cinzas & $0,3-1,0$ \\
Lipídios & $1,0-1,5$ \\
Fibras & $0,4-0,5$ \\
Carboidratos (amido) & $68,0-76,0$ \\
\hline
\end{tabular}

FONTE: SCHOPMEYER, 1960.

\subsection{2 Água, sal e fermento}

A água é essencial na formulação de pães, pois desempenha um papel muito importante na formação da rede de glúten e na transferência de substâncias durante a fermentação. Fisicamente, ela contribui para a elasticidade e consistência da massa, textura e maciez do pão.

A função principal do sal ( $\mathrm{NaCl})$, é conferir sabor e, em quantidade ideais, aumenta a estabilidade da rede de glúten, melhorando a força da massa, regula a velocidade de fermentação e a absorção de água da massa.

Na produção de pão, o fermento empregado é a levedura Saccharomyces cerevisae. Esse microrganismo age durante a fermentação transformando açúcares em gás carbônico e álcool. O fermento pode ser encontrado de três formas diferentes: granular, prensado e seco ativo.

\subsubsection{Coadjuvantes tecnológicos}

Segundo BRASIL (1997), coadjuvante tecnológico é definido como toda substância que não se consome por si só como ingrediente alimentar e é empregada intencionalmente na elaboração de matérias-primas, alimentos ou seus ingredientes, para atender uma finalidade tecnológica durante o tratamento ou fabricação. Admitese no produto final a presença de traços de substância, ou seus derivados.

Em concentrações adequadas, essas substâncias melhoram a qualidade do pão, neutralizam a deficiência de alguns ingredientes e aumentam a sua vida-de- 
prateleira. Entre elas, podemos citar: sal, amilases, emulsificantes, oxidantes, agentes branqueadores e os inibidores da flora microbiana (LEONHARDT, 1999).

Normalmente a farinha contém $2 \%$ de açúcares que são consumidos no início da fermentação. A enzima $\alpha$-amilase atua nos grãos danificados de amido produzindo dextrinas. A $\beta$-amilase produz maltose pela hidrólise da dextrina que é consumida pelas leveduras do fermento. Algumas farinhas necessitam de correção na quantidade de $\alpha$-amilase para serem consideradas panificáveis (LEONHARDT, 1999), já que essa enzima está presente em baixas quantidades no endosperma do grão de trigo. Uma farinha panificável apresenta o falling number próximo de $250 \mathrm{~s}$. O falling number é uma medida da atividade da enzima e é baseada na habilidade da $\alpha$-amilase de liquefazer um gel de amido.

A adição de oxidantes melhora as propriedades reológicas da massa e aumenta a retenção do gás. $O$ ácido ascórbico, um dos mais utilizados, é convertido em ácido dehidro-ascórbico durante a preparação da massa. Esse composto oxida os componentes da farinha, em particular o grupo -SH das proteínas, elevando o potencial elástico da rede protéica formadora de glúten (NAKAMURA; KURATA, 1997; SPICHER; BRÜMMER, 1995).

Emulsificantes são substâncias que possuem tanto a porção polar (solúvel em água; hidrofílica), como a apolar (insolúvel em água; hidrofóbica). Esse aditivo reduz a superfície de tensão entre fases imiscíveis, possibilitando a formação de uma emulsão (STAMPFLI; NERSTEN, 1995). Na panificação, é esperado que o emulsificante melhore diversas características, entre elas: a maquinabilidade da massa, textura, simetria, volume, maciez do miolo, aumento de vida-de-prateleira e maior retenção do gás na massa (CAUVAIN; YOUNG, 1999; PALMA; CICHELLO; PAVANELLI, 2004).

\subsubsection{Amido resistente de milho (ARM)}

O termo amido resistente (AR) foi sugerido inicialmente por Englyst, Wiggins e Cummings (1982), quando constataram que muitos alimentos processados continham maior teor aparente de polissacarídeos não-amidos do que os da fonte originalmente empregada para sua preparação. Análises detalhadas revelaram que este aumento estava relacionado à presença de $\alpha$-glucanos, que poderiam ser 
detectados como glicose após serem dispersos em hidróxido de potássio e submetidos à hidrólise por enzimas amilolíticas.

Definiu-se AR como "a soma do amido e seus produtos de degradação que não são absorvidos no intestino delgado de indivíduos saudáveis" (ASP, 1992).

Estudos têm mostrado que o $A R$ possui funções fisiológicas similares às fibras alimentares (EERLINGEN; DELCOUR, 1995), e pode ser classificado em quatro tipos: o amido fisicamente inacessível (tipo I ou RS1), como o de sementes ou leguminosas; frações não gelatinizadas de amido pouco suscetíveis a ataques enzimáticos, como aquele presente na banana verde ou em batata nativa (tipo II ou RS2); amido gelatinizado retrogradado (tipo III ou RS3); e aquele modificado para adquirir resistência à digestão (tipo IV ou RS4) (GOLDRING, 2004).

Segundo a Legislação Brasileira (BRASIL, 1997), os amidos são considerados ingredientes de produtos de panificação, não possuindo, portanto, limite máximo de adição. Nos Estados Unidos, o AR não modificado quimicamente é reconhecido como GRAS (Generally Recognized as Safe), e na Europa e em diversas outras partes do mundo, o AR não modificado quimicamente pode ser comercializado e consumido por consistir em um componente natural produzido por técnicas tradicionais de cultivo de plantas. Estudos mostram que doses diárias de até $60 \mathrm{~g}$ de $\mathrm{AR}$, proveniente de milho com alto teor de amilose, em humanos não estão associadas a efeitos adversos (GOLDRING, 2004).

Além de não ser considerado aditivo alimentar, o amido resistente possui cor branca, e apresenta-se na forma de pó, sendo uma opção para aplicação em alimentos ricos em amido. $O$ amido resistente de milho (ARM), quando comparado com outras fibras, apresenta benefícios como aparência, sabor e textura que estimula o consumo desse ingrediente funcional.

Alguns amidos, como o Hi-Maize $\AA^{8} 260$ da National Starch, possuem teor de AR em torno de 60 \% (base seca), e são resistentes a altas temperaturas (115 a 120) ${ }^{\circ} \mathrm{C}$, podendo ser submetidos a processos como cocção do pão no forno. $\mathrm{A}$ absorção de água do Hi-Maize® 260 também é reduzida, $25 \%$ superior à da FT, enquanto que a de outros tipos de fibra, como trigo, aveia e a celulósica possuem absorção de água de cerca de 3 a 5 vezes maior que a da FT. Na produção de pães, o fabricante recomenda o uso de (5 a 20) \% base ingredientes secos, equivalente a (5 a 17) \% de substituição da FT pelo produto (NATIONAL STARCH, 2005). 
Métodos para determinação de AR foram propostos por digestão enzimática in vitro, como o de Englyst, Wiggins e Cummings (1982), o de ${ }^{3}$ Berry (1986) apud McClearly e Monaghan (2002), o de Champ (1992), o de ${ }^{4}$ Faisant et al. (1995) apud McClearly e Monaghan (2002) e o de Goñi et al. (1996). O método atualmente aprovado pela AOAC (Association of Official Agricultural Chemists) é o método $2002.02 \quad$ (McCLEARLY; MCNALLY; ROSSITER, 2002; MCCLEARLY; MONAGHAN, 2002).

O AR vem sendo estudado como ingrediente em alimentos, para proporcionar menor resposta glicêmica após sua ingestão (ÅKERBERG; LILJEBERG; BJÖRCK, 1998; GOÑl et al., 1996). LILJEBERG, et al. (1995) estudaram a formação de AR pelo método proposto por ${ }^{5} \mathrm{Holm}$ et al. (1986) apud LILJEBERG et. al. (1995), em pão de centeio produzido com alterações no processo de assamento do pão, de 40 minutos a $200{ }^{\circ} \mathrm{C}$ para 20 horas a $120^{\circ} \mathrm{C}$ e os autores constataram aumento significativo do teor de AR.

Rosin; Lajolo e Menezes (2002) determinaram a concentração de AR pelo método proposto por Goñi et al. (1996), em pães armazenados a $-20^{\circ} \mathrm{C}$, e observaram que a quantidade de AR aumentou $8 \%$ durante o período de 30 dias.

Hung e Morita (2004) verificaram o efeito da substituição de (0, 5, 10 e 15) \% de FT por 3 diferentes tipos de amido de milho com ligações cruzadas por análises farinográficas, com o intuito de aumentar o teor de amido resistente no pão de forma. As misturas foram preparadas e amostras contendo $92 \%$ de mistura e $8 \%$ de glúten vital foram comparadas às amostras de farinha sem substituição. A absorção de água variou de $(59,0$ a 62,4$) \%$ e a estabilidade das misturas com glúten foi maior ou igual à do controle. Foram preparados pães de forma com essas misturas e deixados em temperatura ambiente por cinco dias, durante os quais os autores observaram menor dureza do miolo nas amostras e maior volume do pão com $5 \%$ e $10 \%$ de substituição, em relação ao controle.

\footnotetext{
${ }^{3}$ BERRY, C.S. Resistant starch: formation and measurement of starch that survives exhaustive digestion with amylolytic enzymes during the determination of dietary fibre. Journal of Cereal Science, 4, 301-314, 1986.

${ }^{4}$ FAISANT, N., PLANCHOT, V., KOZLOWSKI, F., PACOURET, M.P., COLONNA, P., CHAMP, M. Resistant starch determination adapted to products containing high level of resistant starch. Sciences des Aliments, 15, 83-89, 1995.

${ }^{5}$ HOLM, J., BJÖRCK, I., DREWS, A., ASP, N.-G. A rapid method for the analysis of starch. Starch/Stärke, 38, 294-297, 1986.
} 
Hung; Yamamori e Morita (2005) estudaram o efeito da substituição de FT convencional por uma com maior teor de amilose. Os ensaios em farinógrafo mostraram que essa substituição ocasionou um decréscimo da estabilidade da mistura de 20 min para aproximadamente 5 min e aumento da absorção de água de $(69,0$ para 85,0$) \%$. Os autores também estudaram a formação de AR em pães de forma durante $\mathrm{O}$ armazenamento a $22{ }^{\circ} \mathrm{C}$ em 4 pontos ao longo de 5 dias, observando aumento do conteúdo de $A R$ entre os pontos 0 e 1 dias de armazenamento devido à retrogradação da amilose.

Segundo MATSUDA (2007), a partir de $15 \%$ de substituição de farinha de trigo (FT) por amido resistente de milho (ARM) os resultados obtidos pelo alveógrafo e reofermentógrafo demonstraram o enfraquecimento da massa produzida das misturas. As misturas foram produzidas entre $(0-30) \%$ de substituição de FT por ARM. A absorção de água das misturas variou entre $(61,5$ e 63,5$) \%$, um aumento de $2 \%$ da substituição máxima em relação ao controle. $O$ teor de glúten úmido indicou que amostras com substituição maiores que 8,5 \% apresentaram a qualidade do glúten comprometida. $\mathrm{O}$ autor concluiu que para as misturas, o nível adequado de substituição de FT por ARM para produzir massa com desempenho de panificação encontra-se entre (5 e 15) \%.

O índice glicêmico (IG) é uma classificação do potencial aumento de glicose no sangue após a ingestão de carboidratos. O interesse dos consumidores no IG tem aumentado nos últimos anos, e o maior desafio da indústria alimentícia está em desenvolver e produzir alimentos com baixo IG (BURTON; LIGHTOWLER, 2008). Segundo estudos realizados por Warren et al. (2003), alimentos com baixo IG podem reduzir a fome e resultar em uma menor energia absorvida.

Yamada et al. (2005) estudaram a resposta glicêmica em humanos após o consumo de pães convencionais e contendo AR e observaram que para indivíduos com nível inicial de glicose superior ao normal, a resposta glicêmica após o consumo do pão com AR foi significativamente menor que a resposta obtida do pão convencional, ao passo que, para indivíduos com nível de glicose inicial dentro da normalidade, as respostas ao consumo dos dois tipos de pães não apresentaram diferenças significativas. 


\subsubsection{Enzima transglutaminase na panificação}

A transglutaminase (TG) pertence à família de enzimas que catalisam a formação de ligações covalentes entre um grupo amina livre (por exemplo: proteína ou peptídeo - ligação lisina) e o grupo $\gamma$-carboxamida do resíduo glutâmico. As ligações formadas por esta enzima exibem alta resistência à degradação proteolítica. Devido à formação de ligações inter e intramoleculares, a TG é melhor tolerada aos efeitos negativos que podem ocorrer com super dosagem de enzimas tradicionalmente utilizadas em panificação. Esses efeitos negativos não são identificados pelos autores. Seu uso em panificação é relativamente novo (GOESAERT et al., 2005).

Basman, Köksel e $\mathrm{Ng}$ (2002) estudaram o efeito da adição da transglutaminase em seis níveis sobre as propriedades reológicas e de panificação de dois tipos de farinha de trigo (Roane e Sharpshooterl). Os resultados indicaram que a adição da enzima pode melhorar o desempenho de panificação, entretanto nos níveis mais elevados, a adição da enzima apresentou efeitos negativos para ambos os tipos de farinha utilizados. Os autores sugerem um nível otimizado para cada aplicação.

Collar e Bollaín (2004) estudaram o impacto da transglutaminase microbiana sobre o perfil viscoelástico de massas de pão formuladas em combinação com hidroxipropilmetilcelulose (HMC) e uma pectina com alto conteúdo de éster. Pelo método de superfície de resposta os autores encontraram massas altamente coesas com um aumento da capacidade de retenção de água e força do glúten durante a mistura, fermentação e no assamento de misturas que continham a enzima, a pectina e o emulsificante DATEM. Os autores citados reportaram efeitos benéficos da adição de TG nas propriedades de textura da massa: a adição de 0,422 \% (base farinha) resultou no aumento da coesividade e elasticidade devido ao aumento de ligações entre proteínas.

Basman, Köksel e $\mathrm{Ng}$ (2002) relataram que o aumento do nível de TG $(0-1,5) \%$, base mistura, aumentou significativamente $(p<0,05)$ a resistência máxima à extensão e diminuiu a extensibilidade na ruptura, em massas produzidas com diferentes farinhas de trigo. 


\subsection{Produção da massa do Pão de forma}

Existem alguns passos comumente seguidos em todos os processos de fabricação de pães em que farinha de trigo é convertida em um alimento aerado e palatável (CAUVAIN, 1999):

- Mistura de farinha e água, junto com sal e fermento, além de outros ingredientes específicos em proporções adequadas.

- Desenvolvimento da estrutura de glúten (proteínas hidratadas) e incorporação de ar na massa pela energia aplicada durante o batimento, também chamado de amassamento.

- Contínuo desenvolvimento da estrutura de glúten formada como resultado do amassamento, de modo que as propriedades reológicas e desejáveis da massa e o aumento da habilidade de expandir (quando a pressão de gás aumenta devido a geração de dióxido de carbono $\left(\mathrm{CO}_{2}\right)$ na fermentação da massa) sejam obtidos.

- Criação ou modificação de componentes aromatizantes na massa.

- Divisão da massa em pequenas peças.

- Modelagem dos pequenos pedaços de massa.

- Fermentação da massa pela levedura e produção de $\mathrm{CO}_{2}$ e álcool.

- Cozimento.

- Resfriamento, embalagem e armazenamento.

\subsection{Métodos de ensaio utilizados}

Análises térmicas têm sido comumente utilizadas em análise de alimentos como rotina de processo e controle de qualidade, além de pesquisa e desenvolvimento. A calorimetria exploratória diferencial (DSC, do inglês Differential Scanning Calorimetry) mede a diferença entre o fluxo de calor na amostra e na referência, usualmente uma cápsula de alumínio vazia, quando submetidas a um mesmo programa de temperatura (RAHMAN, 1995). O fluxo de calor corresponde à energia transmitida e é medida em watts (W). Se o fluxo de energia é integrado em relação ao tempo, obtêm-se a quantidade de energia absorvida ou liberada $(\mathrm{mW} \cdot \mathrm{s}=\mathrm{mJ})$. Dois tipos de informações podem ser obtidos das curvas de DSC: 
temperaturas de transição e propriedades relacionadas a entalpia (calor latente, entalpia, calor específico e taxa de reação) (RAHMAN, 1995). É uma ferramenta bastante útil para o estudo de transições de primeira ordem, como a gelatinização e retrogradação do amido, durante $\mathrm{o}$ assamento e armazenamento de produtos de panificação (RIBOTTA; LEÓN; AÑÓN, 2003). Durante a análise quando a amostra e a referência são submetidas a um programa de calor a uma dada taxa constante, qualquer diferença de temperatura será função de: entalpia de mudança; a capacidade calorífica e; a resistência térmica total ao fluxo de calor, de modo que permitirá estudar a gelatinização do amido de trigo e a do amido resistente presentes na massa, e também observar a influência causada pela adição da enzima transglutaminase.

Devido ao curto tempo de vida de prateleira dos pães, existem ensaios de textura que simulam o consumo (mastigação), como o TPA (do inglês Texture Profile Analysis) e quantificam o endurecimento. Alguns desses ensaios também são utilizados na massa do pão para caracterizá-la e prever sua qualidade após o assamento: são os ensaios de extensão e resistência uniaxial e biaxial.

Outro ensaio bastante utilizado em panificação é o realizado em reofermentógrafo, que simula a fermentação da massa e fornece duas curvas típicas: a do desenvolvimento da massa e a da sua capacidade de reter o gás, sob condições controladas. Das curvas obtidas, a qualidade da fermentação e da rede protéica formada, isto é, a quantidade de gás produzido pela levedura e a tolerância da massa à fermentação podem ser avaliadas, que dependem basicamente da farinha, do fermento e dos aditivos utilizados na massa.

Os teores de glúten úmido e seco são parâmetros bastante observados em panificação, pois determinam o quanto uma farinha/mistura consegue realmente desenvolver o glúten. Esses fatores influenciarão diretamente no volume final do pão. Segundo Pizzinato (1997), uma farinha panificável deve conter entre (23 - 30) \% de glúten úmido. Existem duas formas de determinar o glúten úmido: manualmente, ou no equipamento Glutomatic, no qual a massa é preparada e lavada automaticamente, retirando todo amido e restando apenas a rede de glúten. O excesso de água presente no glúten obtido é retirado por centrifugação. $O$ teor de glúten seco é obtido colocando essa massa no equipamento chamado Glutork, composto por duas placas revestidas com teflon a $150{ }^{\circ} \mathrm{C}$, e prensada por 4 minutos. 
Outro equipamento bastante utilizado para avaliar e controlar a qualidade da farinha de trigo é o farinógrafo. Nele, enquanto a massa é misturada, o torque produzido pela resistência da massa à mistura é registrado, medido como viscosidade, durante sucessivos estágios do seu desenvolvimento (PIZZINATO, 1997). Com isso, torna-se possível avaliar a mistura quanto à capacidade de absorção de água e resistência ao amassamento durante o processo de fabricação de pães. 


\section{MATERIAIS E MÉTODOS}

Foram produzidas massas de pão com cinco níveis de substituição da farinha de trigo (FT) pelo amido resistente de milho (ARM): 1,5 \%; 3,5 \%; 8,5 \%; 13,5\%; $15,5 \%$ (base $100 \%$ mistura); e cinco níveis de adição de enzima transglutaminase (TG): $0,03 \% ; 0,05 \% ; 0,10 \% ; 0,15 \% ; 0,17 \%$ e seu perfil de textura, reológico e térmico analisado.

Os experimentos foram conduzidos de acordo com um planejamento experimental estrela de segunda ordem $\left(2^{2}\right)$, com três pontos centrais, para estimar o erro puro, e quatro pontos axiais conforme a Tabela 3-1.

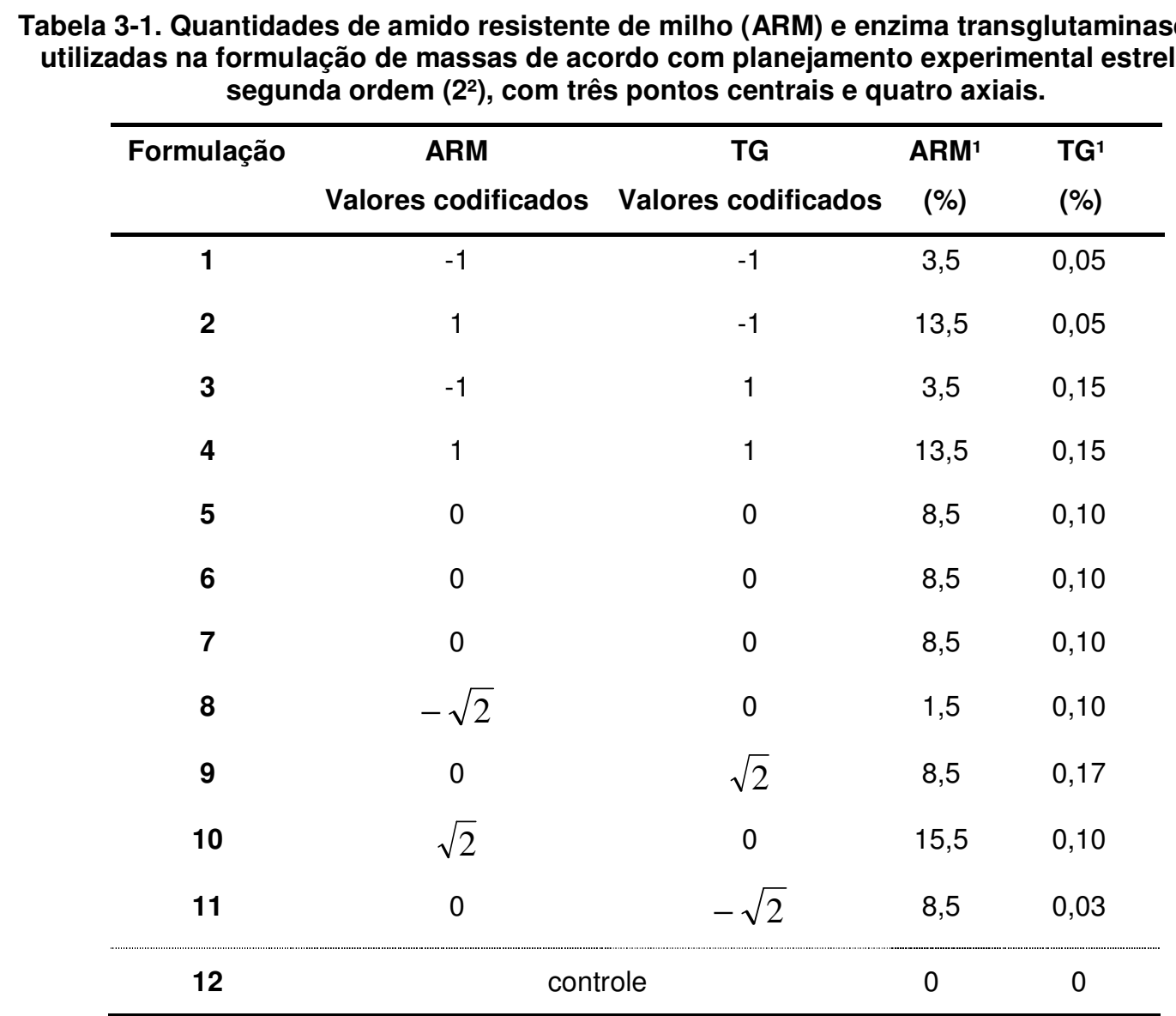

${ }^{1}$ base $100 \%$ de mistura

Foram conduzidos os mesmos ensaios com massa preparada somente com a farinha de trigo (controle), sem adição de ARM e TG, e os resultados utilizados para comparação. 


\subsection{Materiais}

Os ingredientes utilizados nesse estudo foram:

- farinha de trigo comercial (Triticum spp) do moinho Tirani S.A. (Argentina) e do Moinho Pacífico (laudo apresentado Tabela 3-2);

- amido resistente de milho comercial marca Hi-Maize® 260, doado pela National Starch (Brasil), contendo aproximadamente $60 \%$ de fibras e com temperatura de gelatinização em torno de $120{ }^{\circ} \mathrm{C}$ (NATIONAL STARCH, 2005);

- enzima transglutaminase Activa ${ }^{\mathrm{TM}} \mathrm{TG}$ (100 U/g atividade) obtida da Ajinomoto (Japão);

- sal;

- água destilada;

- fermento biológico fresco (Saccharomyces cerevisae), da marca Fleischmann;

- ácido ascórbico grau P.A., fabricado pela Casa Americana;

- emulsificantes DATEM (monoglicerídeos de ésteres de ácido tartárico diacetilado), PANODAN® ALB 10 PS, e enzima alfa-amilase fúngica GRINDAMYLTM A 4000, doados pela Danisco S/A.

Tabela 3-2. Laudo da farinha M. Extra - PT (MOINHO PACÍFICO, 2008).

\begin{tabular}{|c|c|c|c|}
\hline ANÁLISES & $\begin{array}{c}\text { RESULTADOS } \\
\text { FÍSICO-QUÍMICOS }\end{array}$ & ANÁLISES & $\begin{array}{l}\text { RESULTADOS } \\
\text { REOLÓGICOS }\end{array}$ \\
\hline UMIDADE & $13,8 \%$ & \multirow{7}{*}{$\begin{array}{r}\text { FARINÓGRAFO } \\
\text { Estabilidade } \\
\text { Absorção } \\
\text { ITM } \\
\text { EXTENSOGRAMA } \\
\text { Resistência } \\
\text { Extensibilidade } \\
\text { Absorção } \\
\text { ALVEOGRAMA }\end{array}$} & \\
\hline CINZAS & $0,759 \%$ & & $\begin{array}{l}8,9 \min \\
61,0 \%\end{array}$ \\
\hline GLÚTEN SECO & $9,7 \%$ & & 33 U.F. \\
\hline GLÚTEN ÚMIDO & $29,1 \%$ & & $3883 \mathrm{UF}$ \\
\hline FALLING NUMBER & $448 \mathrm{~s}$ & & $\begin{array}{c}173,66 \mathrm{~mm} \\
58,6 \%\end{array}$ \\
\hline \multirow[t]{2}{*}{ COR } & $L 92,20$ & & \\
\hline & & & $\begin{array}{c}P=93 ; L=70 ; \\
W=237 ; P / L=1,32\end{array}$ \\
\hline
\end{tabular}




\subsection{Métodos}

3.2.1 Preparo das massas para as análises de extensão uniaxial, biaxial e TPA (do inglês Texture Profile Analysis)

As formulações foram preparadas em base de $100 \mathrm{~g}$ de mistura (FT e ARM), $60 \mathrm{~mL}$ de água miliRO, $2 \mathrm{~g}$ de sal, e as quantidades de TG e ARM adicionadas de acordo com o indicado na Tabela 3-1. A mistura dos ingredientes, seguida do batimento para formação da rede de glúten, foram conduzidos para o preparo das massas.

Para o teste de extensão uniaxial e TPA, as massas foram produzidas conforme segue: os ingredientes secos foram misturados com a água (base $100 \mathrm{~g}$ de mistura) sob velocidade dois por 1,5 min em batedeira Philips HR 1495 (Philips, Argentina), seguido de descanso da massa por $10 \mathrm{~min}$. A Figura 3-1 ilustra como as massas foram preparadas para os testes mencionados acima.

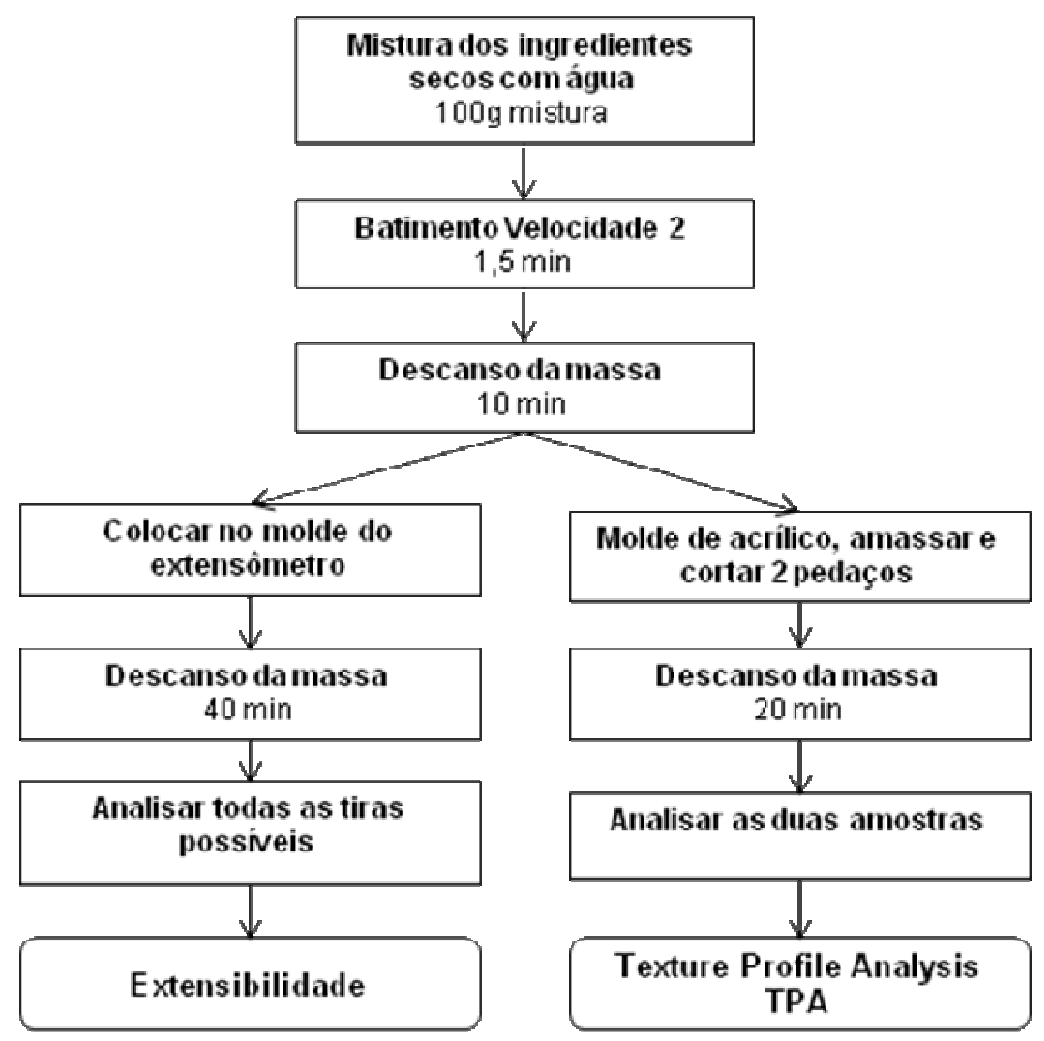

Figura 3-1. Esquema do preparo das massas para os testes de extensão uniaxial e Texture Profile Analysis (TPA). 
Para o teste TPA, uma porção da massa, com aproximadamente $120 \mathrm{~g}$, foi manualmente laminada em uma base de acrílico, com altura de $8 \mathrm{~mm}$ (Figura 3-2), dividida em dois pedaços, mantidos em descanso por 20 min cobertos com plástico para evitar perda de umidade e, em seguida submetidos ao teste.

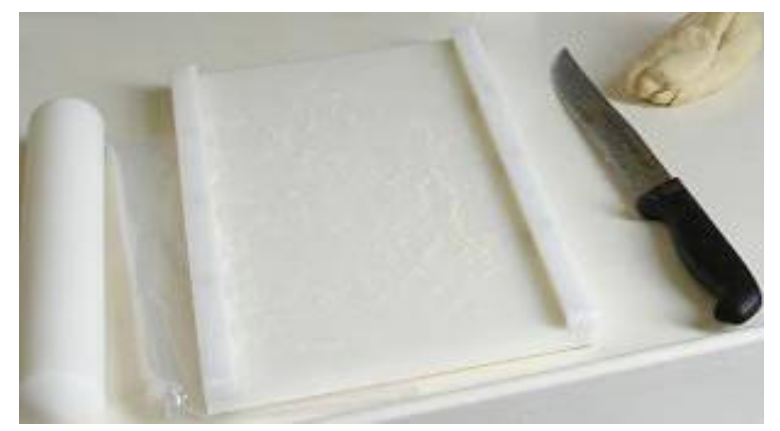

Figura 3-2. Molde de acrílico com $8 \mathrm{~mm}$ de espessura usado para moldar as massas para 0 teste de TPA e extensão biaxial (Dough Inflation System).

A porção de massa restante foi comprimida no molde de blocos próprio (Figura 3-3) lubrificado com vaselina líquida, em tiras, conforme o método Kieffer (SMS, 1995). Após 40 minutos de descanso à temperatura ambiente, as tiras foram submetidas ao teste de extensão uniaxial.

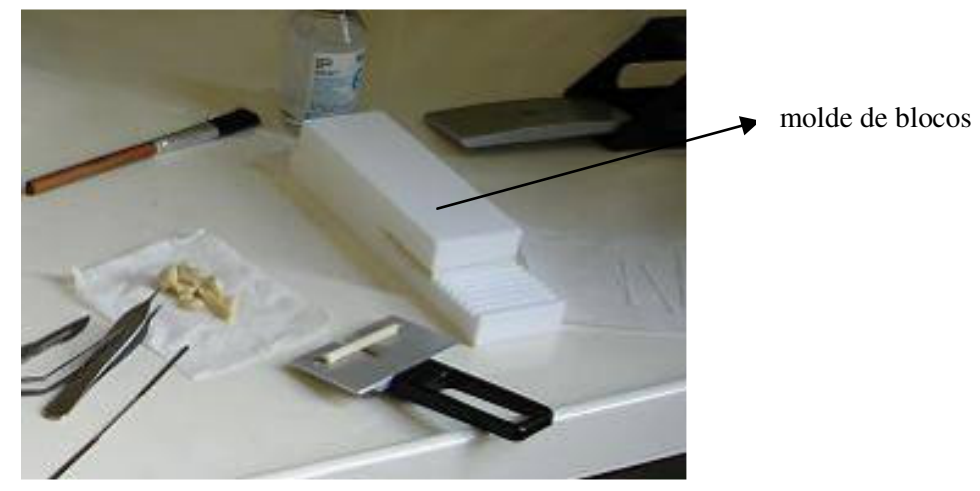

Figura 3-3. Molde de blocos para preparação das tiras de massa para o teste de extensão uniaxial.

Para o teste de extensão biaxial (Dough Inflation System) os ingredientes secos (base $400 \mathrm{~g}$ de mistura), foram misturados com água miliRO em velocidade dois por 8 min em uma masseira Argental L-20 (Argental, Argentina) ilustrada na Figura 3-4. 


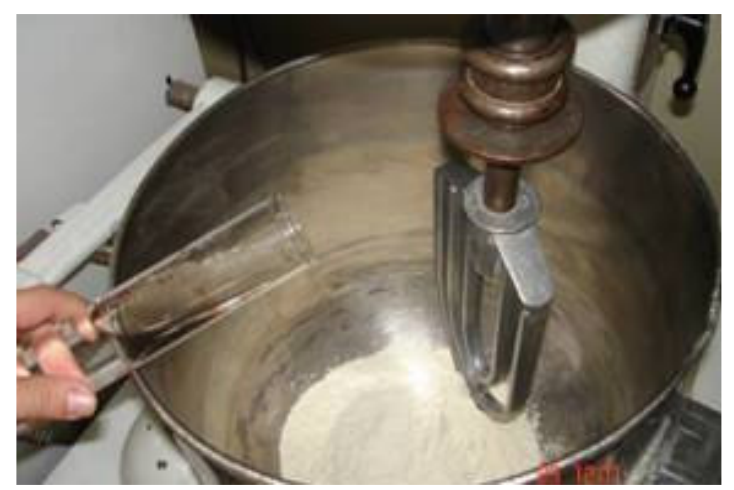

Figura 3-4. Masseira Argental.

Após descanso de $10 \mathrm{~min}$, à temperatura ambiente, a massa foi laminada na base de acrílico, com altura $8 \mathrm{~mm}$ (Figura 3-2), e cortada, com auxílio de um molde, em cinco círculos (réplicas) que foram colocados dentro de discos, pressionados por $30 \mathrm{~s}$ com um equipamento especial do texturômetro e empilhados com tampa (Figura 3-5), por 30 minutos, para evitar a perda de umidade. Em seguida, os discos de massa foram submetidos ao teste de extensão biaxial, conforme o método $D / R$ Dobrasczcyk (SMS, 1995). A Figura 3-6 ilustra a sequência de etapas da preparação dos discos de massa para o teste de extensão biaxial (Dough Inflation System).

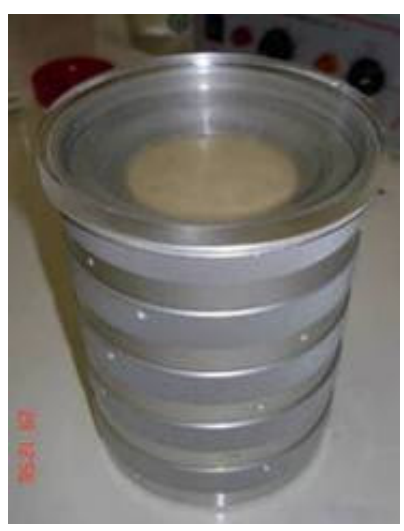

Figura 3-5. Amostras moldadas em discos 


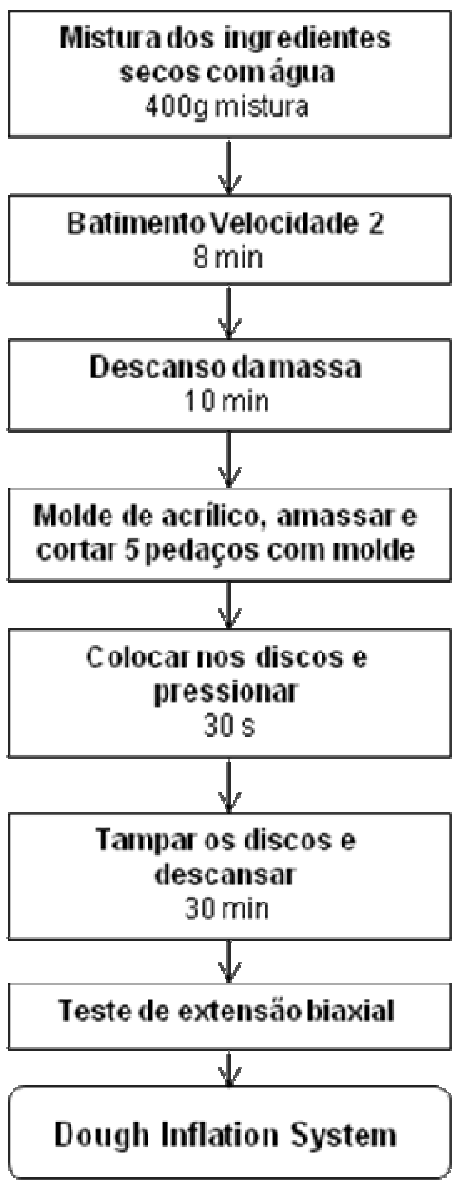

Figura 3-6. Esquema do preparo das massas para o teste de extensão biaxial (Dough Inflation System).

\subsubsection{Preparo das massas para as análises de Calorimetria Exploratória Diferencial (DSC)}

Devido a necessidade de quantidades de massa muito pequenas para as análises de DSC, entre (15 e 20) mg, as mesmas foram preparadas em um micro farinógrafo Brabender (Figura 3-7). Os ingredientes utilizados foram: farinha de trigo procedente da Argentina e amido resistente de milho (base $10 \mathrm{~g}$ mistura) conforme o planejamento experimental, $60 \%$ de água destilada e $2 \%$ de sal. O tempo de amassamento foi de $6 \mathrm{~min}$, a partir do momento da adição de água. 


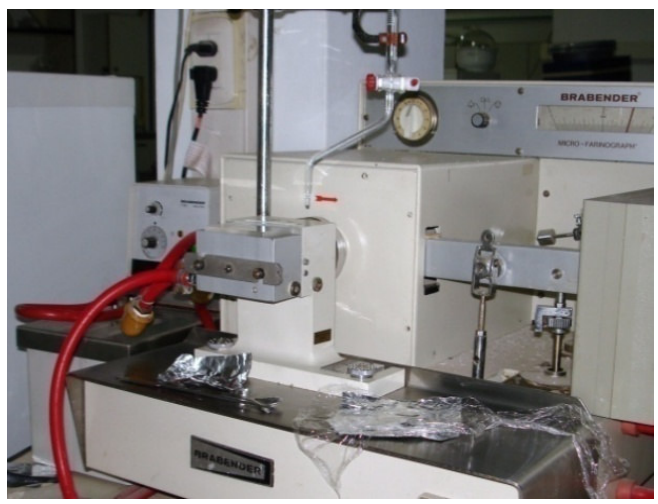

Figura 3-7. Micro-farinógrafo Brabender utilizado no preparo das massas para análise de DSC.

As massas prontas foram pesadas em balança analítica e hermeticamente seladas nas cápsulas de alumínio (Figura 3-8). Depois de realizado os ensaios, as cápsulas foram furadas na tampa e mantidas durante $24 \mathrm{~h}$ em estufa à $105^{\circ} \mathrm{C}$ para determinar o conteúdo de matéria seca, usado no cálculo da entalpia.

A temperatura onset e as entalpias $(\Delta H)$ foram calculadas com o auxílio do software Universal Analysis 2000 v 4.3E (TA Instruments).

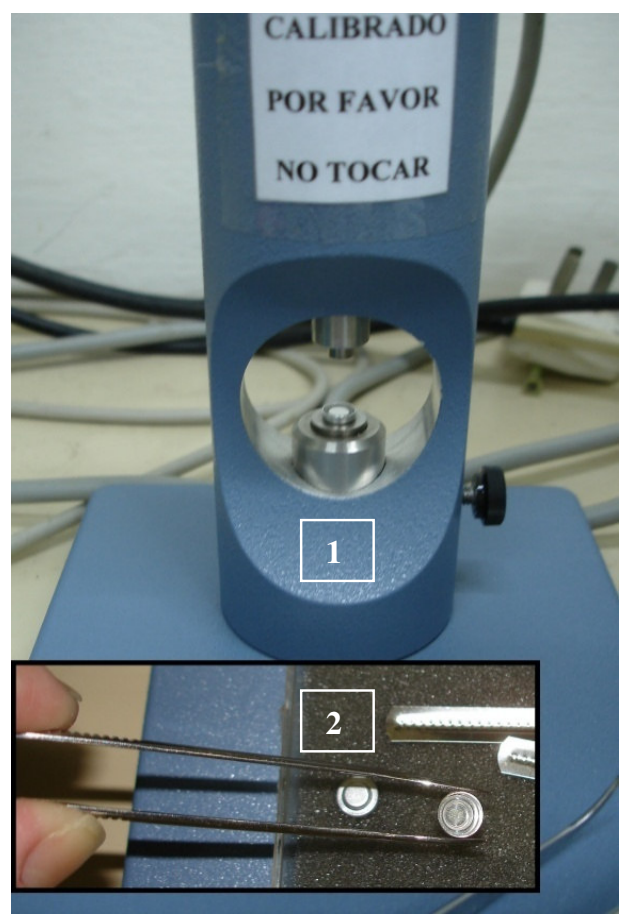

Figura 3-8. (1) Seladora de cápsulas de alumínio para análise de DSC. (2) Cápsulas de alumínio. 


\subsubsection{Preparo das massas para as análises no reofermentógrafo}

Esse procedimento foi realizado em masseira espiral (Supremax, Brasil) em duas etapas: na primeira na velocidade 1, onde a água foi incorporada pela farinha de trigo, e na segunda, na velocidade 2, para ocorrer o desenvolvimento do glúten.

A farinha de trigo sem aditivos foi analisada preliminarmente no reofermentógrafo, e para corrigir e melhorar seus parâmetros (altura de desenvolvimento da massa, produção de $\mathrm{CO}_{2}$, volume retido de $\mathrm{CO}_{2}$ e correção do falling number), foram adicionados alguns coadjuvantes de tecnologia.

A partir desses resultados, foram definidos os seguintes aditivos para correção da farinha: 0,02 \% de ácido ascórbico, 0,3 \% de emulsificante DATEM e $0,0176 \mathrm{~g}$ de enzima $\alpha$-amilase para $1000 \mathrm{~g}$ de mistura (FT + ARM). Esses aditivos foram utilizados em todos os testes realizados.

\subsubsection{Teste de extensão uniaxial}

De cada formulação preparada de acordo com planejamento experimental, aproximadamente 10 tiras de massa foram submetidas ao teste, como mostrado na Figura 3-9, em um texturômetro TA-xT2i (Stable Micro Systems - SMS, UK), com acessório A/KIE Kieffer Dough \& Gluten extensibility rig. As condições de ensaios foram seguidas conforme o método SMS (SMS, 1995), como segue:

- velocidade pré-teste: $2,0 \mathrm{~mm} / \mathrm{s}$

- velocidade de teste: $3,3 \mathrm{~mm} / \mathrm{s}$

- velocidade pós-teste: $10 \mathrm{~mm} / \mathrm{s}$

- distância: $75 \mathrm{~mm}$

- gatilho: auto $0,10 \mathrm{~N}$

- célula de carga de $25 \mathrm{~kg}$ 


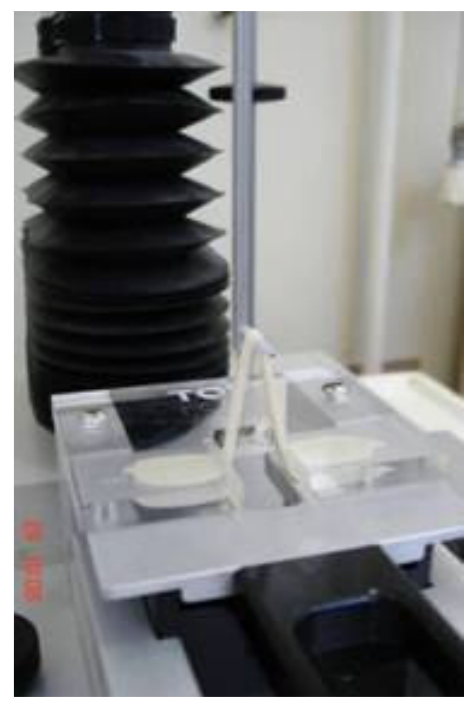

Figura 3-9. Teste de extensão uniaxial da massa de pão realizado no texturômetro TA-xT2i com acessório A/KIE Kieffer Dough \& Gluten extensibility rig.

A Figura 3-10 mostra uma curva típica obtida do teste de extensão uniaxial e com o uso do software Texture Expert versão 1.22, os seguintes parâmetros foram obtidos: resistência à extensão $(F)$ como a força máxima requerida para a ruptura do material, extensibilidade na ruptura $(L)$ como a medida da distância percorrida pela massa até a ruptura e, a energia aplicada à massa $(A)$ até a ruptura.

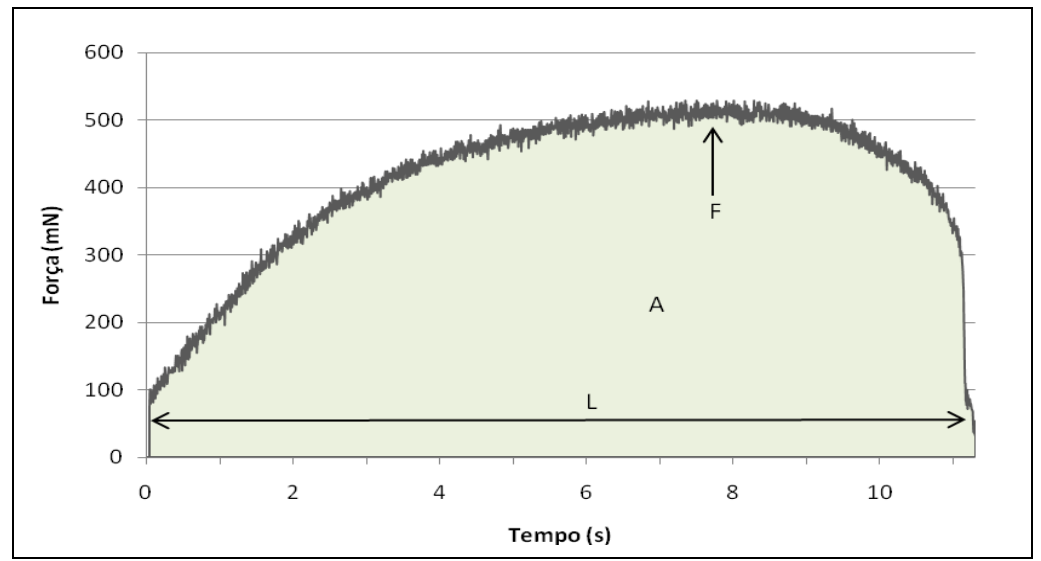

Figura 3-10. Curva típica obtida do teste de extensão uniaxial de massa de pão (F: resistência à extensão, L: extensibilidade na ruptura e A: energia aplicada à massa até a ruptura).

\subsubsection{Teste de extensão biaxial (Dough Inflation System)}

Esse teste consiste na medida da resistência da massa à extensão, obtida pelo insuflamento da massa até sua ruptura. 
Cinco discos de massa preparados conforme descrito no item 3.2.1 foram submetidos ao teste de extensão biaxial, por deslocamento de ar, utilizando o pistão do texturômetro TA-xT2i (SMS, UK) com o acessório Dobraszczyk/Roberts (D/R) Dough Inflation System, como ilustrado na Figura 3-11. A pressão durante o insuflamento foi medida e o aumento do volume da massa foi calculado a partir do deslocamento do pistão ( ${ }^{6}$ DOBRASCZCYK, 1997 apud COLLAR, 2004).

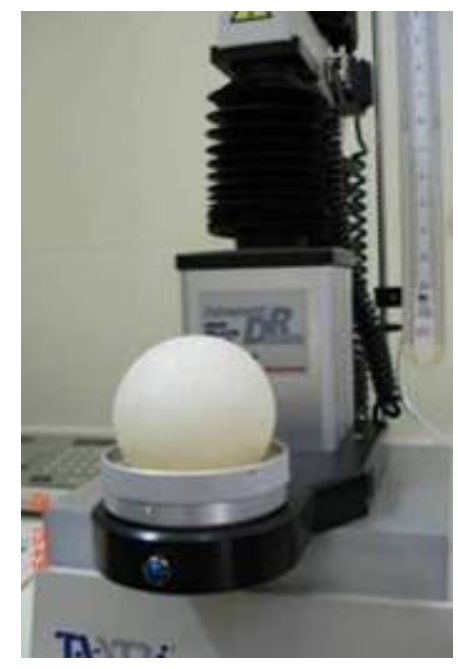

Figura 3-11. Texturômetro TA-xT2i com acessório Dobraszczyk/Roberts (D/R) para o teste de extensão biaxial (Dough Inflation System).

Para cada formulação, cinco réplicas foram realizadas, nas seguintes condições, segundo manual explicativo do acessório (SMS, 1995):

- velocidade pré-teste: $518 \mathrm{~cm}^{3} / \mathrm{s}$

- velocidade de teste: $1602 \mathrm{~cm}^{3} / \mathrm{s}$

- velocidade pós-teste: $1602 \mathrm{~cm}^{3} / \mathrm{s}$

- volume: $785 \mathrm{~cm}^{3}$

- sensibilidade: $24 \mathrm{~Pa}$

As curvas foram obtidas e os parâmetros analisados pelo software D/R Dough Inflation System versão 1.05 (Stable Micro Systems, UK).

${ }^{6}$ DOBRASCZCVK, B. J. Cereal Foods World 42, 516-519, 1997. 
Os parâmetros obtidos das curvas, como mostrado na Figura 3-12, foram tenacidade $(P)$ como a máxima pressão requerida durante o insuflamento da massa, expressa em $\mathrm{mm} \mathrm{H}_{2} \mathrm{O}$, extensibilidade $(L)$ como o comprimento da curva até o ponto de ruptura, expresso em mm, energia de deformação da massa ( $W$ ) como a área da curva (pressão x distância) do início do insuflamento até o ponto de ruptura da amostra, expresso em $J$, e $P / L$ como a razão entre a tenacidade e a extensibilidade.

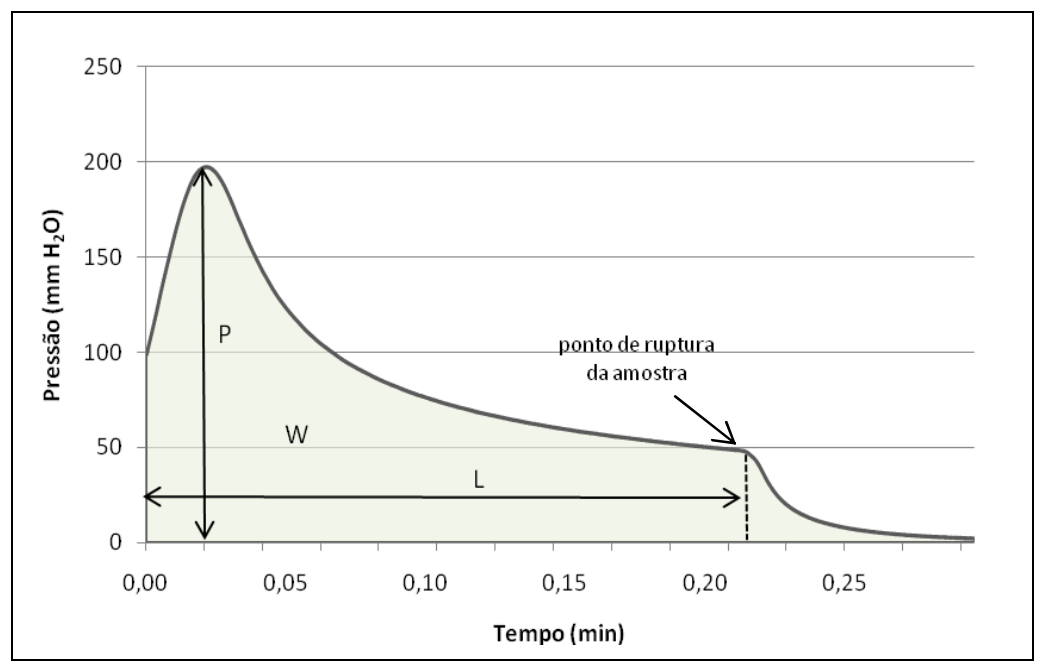

Figura 3-12. Curva típica obtida do teste de extensão biaxial de massa de pão: a tenacidade (P) obtida diretamente da curva e a extensibilidade (L), obtida indiretamente pelo tempo do teste, a uma dada velocidade constante.

\subsubsection{Texture Profile Analysis (TPA)}

Para cada formulação, dois pedaços de massa, previamente preparados e após o descanso, conforme descrito no item 3.2.1, foram submetidos à compressão até $60 \%$ da altura original, aplicando o teste TPA com dupla compressão, utilizando o texturômetro TA-xT2i (SMS, UK) equipado com probe de diâmetro $50 \mathrm{~mm}$ P/50 (ver Figura 3-13). 


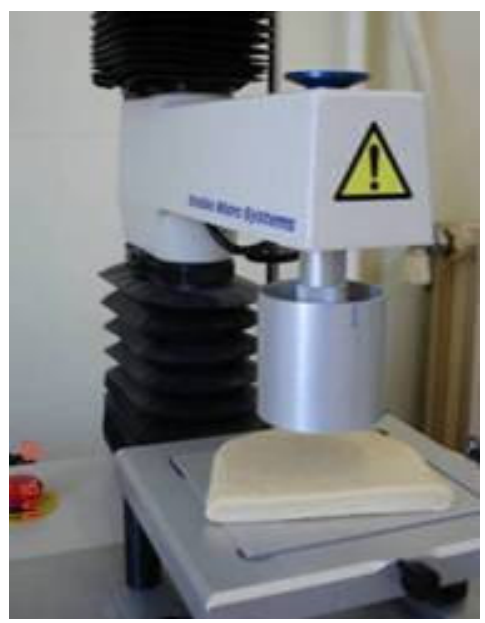

Figura 3-13. Ensaio TPA na massa de pão, no Texturômetro TA-xT2i equipado com probe P/50.

As condições de realização do ensaio aplicado segundo Collar e Bollaín (2004), foram:

- velocidade pré-teste: $1,0 \mathrm{~mm} / \mathrm{s}$

- velocidade de teste: $1,0 \mathrm{~mm} / \mathrm{s}$

- velocidade pós-teste: $1,0 \mathrm{~mm} / \mathrm{s}$

- gatilho: auto 0,2N

- tempo entre compressões: $75 \mathrm{~s}$

- deformação: $60 \%$

- célula de carga de $25 \mathrm{~kg}$

A Figura 3-14 ilustra uma curva típica obtida do teste e os parâmetros como dureza, coesividade, adesividade, elasticidade, e resiliência foram calculados usando o software Texture Expert Version 1.22 (SMS, UK). 


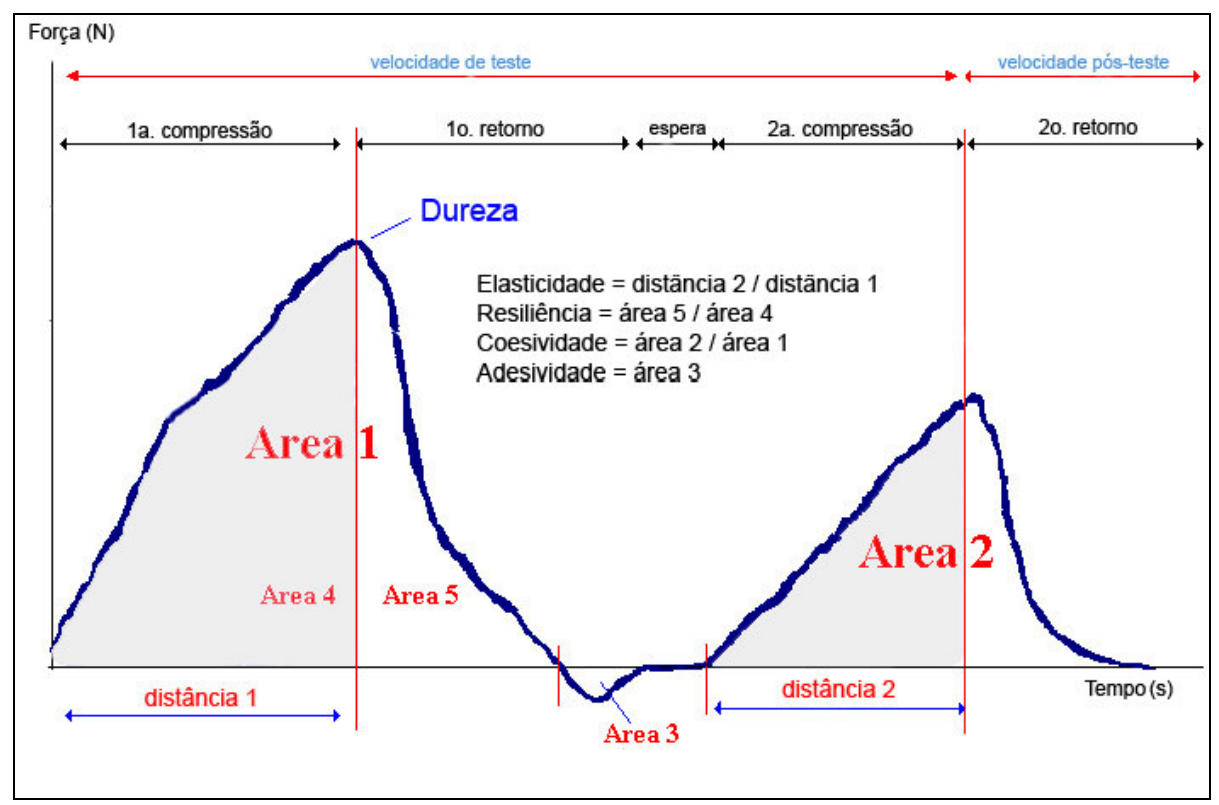

Figura 3-14. Curva típica obtida do teste TPA e os respectivos parâmetros de textura calculados, sendo a área 1 correspondente a $1^{\text {a }}$ compressão e a área 2, à $2^{\mathrm{a}}$ compressão.

A dureza corresponde à força máxima de compressão na $1^{\underline{a}}$ compressão $(\mathrm{N})$.

A coesividade corresponde à razão entre o trabalho realizado sobre a massa durante a $2^{\mathrm{a}}$ compressão e 0 trabalho durante a $1^{\text {a }}$ compressão, expressa normalmente em porcentagem.

A adesividade é calculada pela área da curva obtida após a 1aㅡ compressão, quando o material é espesso ou adesivo, representando o trabalho necessário para desprender a massa do probe quando este retorna a posição inicial (o que justifica a área ser negativa).

A elasticidade da massa representa quanto da estrutura original foi modificada pela $1^{\text {a }}$ compressão. Se a amostra retorna a sua altura original, a elasticidade será 100 \%. Este parâmetro é calculado da altura (distância) da massa após a $2^{\underline{a}}$ compressão dividida pela altura da massa após a $1^{a}$ compressão e, portanto usualmente é expressa em porcentagem.

A resiliência mede a resposta da massa após a compressão quando a força de compressão é interrompida e é determinada do trabalho de retraimento dividido pelo trabalho de compressão, ou seja, a razão entre a área 5 e área 4 indicadas na Figura 3-14, e é usualmente expressa como porcentagem. 


\subsubsection{Análises de Calorimetria Exploratória Diferencial (DSC)}

Os ensaios foram conduzidos para quantificar a gelatinização do amido contido na farinha de trigo e a do amido resistente de milho em equipamento de Calorimetria Exploratória Diferencial (DSC modelo Q100, TA Instruments, EUA) (Figura 3-15), no qual as massas foram submetidas a um programa de temperatura: inicialmente as massas foram equilibradas a $20^{\circ} \mathrm{C}$, em seguida resfriadas à taxa de $5{ }^{\circ} \mathrm{C} /$ min até atingir $-40{ }^{\circ} \mathrm{C}$; após 1 min mantidas nesta temperatura, as massas foram aquecidas à taxa de $5{ }^{\circ} \mathrm{C} / \mathrm{min}$ até $20^{\circ} \mathrm{C}$ e após à taxa de $10^{\circ} \mathrm{C} / \mathrm{min}$ até atingir a temperatura de $150{ }^{\circ} \mathrm{C}$ (Figura 3-16).

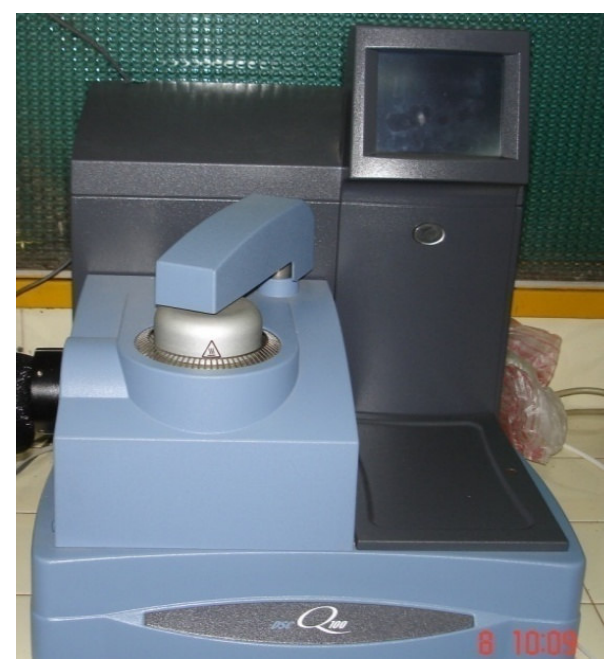

Figura 3-15. Equipamento de calorimetria exploratória diferencial (DSC)

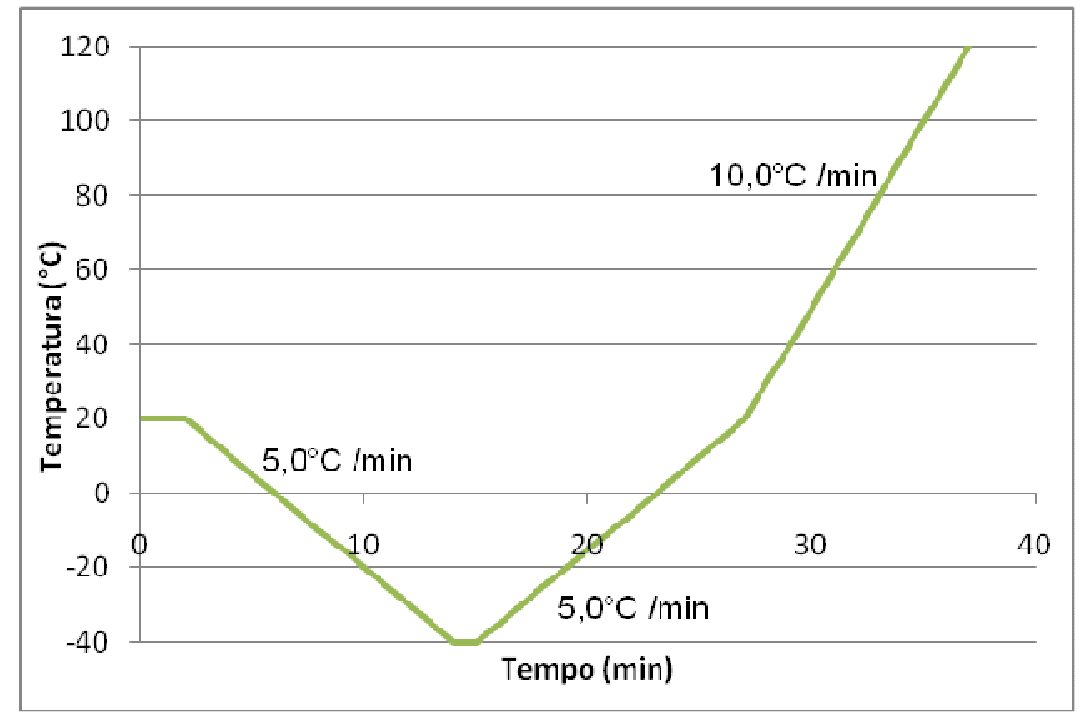

Figura 3-16. Curva do programa de temperatura aplicado nas massas, durante o ensaio do DSC. 
Das curvas obtidas, as temperaturas de onset ( $\left.T_{\text {onset }}\right)$, e as entalpias $(\Delta H)$ dos picos de fusão da água, da gelatinização do amido e a do amido resistente (área dos picos), foram determinadas (Figura 3-17).

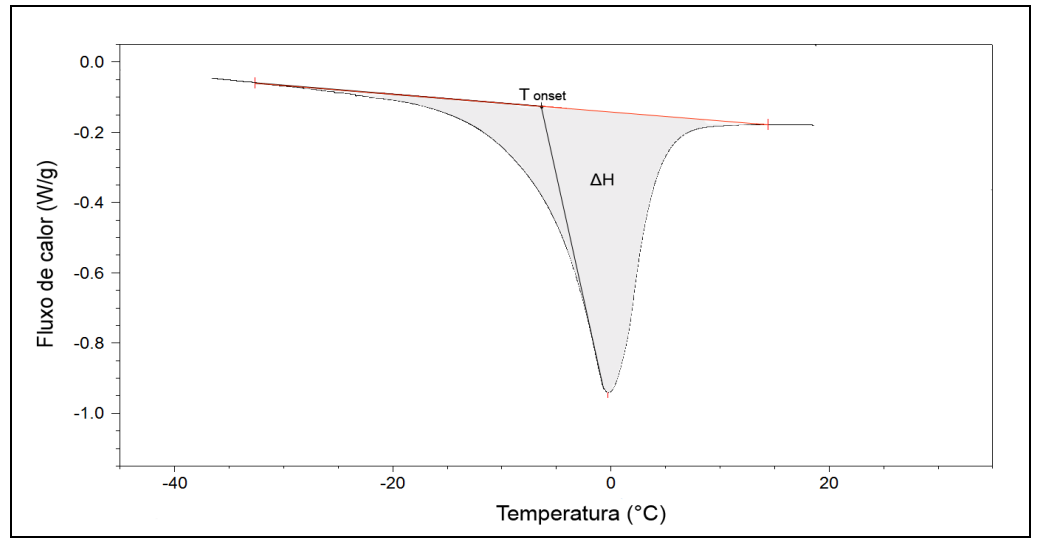

Figura 3-17. Curva típica do DSC com indicação da temperatura onset ( $\left.T_{\text {onset }}\right)$, entalpia $(\Delta H)$ calculado pelo software Universal Analysis 2000 (TA Instruments).

A fração de água congelável ( $F W$ foi obtida pelo pico endotérmico de fusão (próximo de $0{ }^{\circ} \mathrm{C}$ ), onde a entalpia $\left(\Delta_{\text {fus }} H\right)$ foi determinada pela área do pico gerado. O conteúdo total de água $\left(W_{t}\right)$ que foi determinado em estufa foi utilizado para determinar as quantidades de água congelável e não-congelável. A fração de água congelável ( $F W$ foi calculada através da relação entre a entalpia de fusão $\left(\Delta_{f u s} H\right)$ e o calor latente de fusão da água $(\lambda=334 \mathrm{~J} / \mathrm{g})$, conforme mostra a equação 3.1 abaixo:

$$
F W=\frac{\left(\frac{\Delta_{\text {fus }} H}{\lambda}\right)}{w_{t}}
$$

A fração de água não-congelável (UFW), que é a água ligada, foi determinada pela diferença entre a água total e a água congelável, de acordo com a equação 3.2:

$$
U F W=\frac{W_{t}-F W}{W_{t}} \times 100
$$

(equação 3.2) 


\subsubsection{Reofermentógrafo}

As análises foram conduzidas em Reofermentógrafo CHOPIN (modelo F3, França) (Figura 3-18), de acordo com o protocolo CHOPIN (peso: 2 kg; massa: $250 \mathrm{~g}$; fermento prensado: 2,8 \%; duração do teste $3 \mathrm{~h}$; temperatura da câmara: $28,5^{\circ} \mathrm{C}$ ). Para cada ensaio, foram obtidas duas curvas: a primeira conhecida como curva de desenvolvimento da massa indica a altura da massa durante o ensaio, medida através de um sensor ótico; a segunda conhecida como curva de retenção gasosa, a pressão do gás produzido durante o ensaio $\left(\mathrm{ar}+\mathrm{CO}_{2}\right)$ é medida (ciclo direto) por um sensor de pressão, e após a corrente passar por um absorvedor de $\mathrm{CO}_{2}$, a pressão é medida novamente (ciclo indireto).

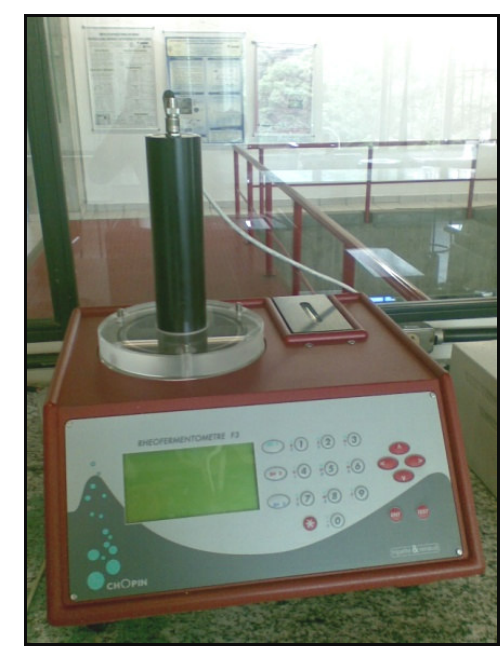

Figura 3-18. Reofermentógrafo F3 CHOPIN

A Figura 3-19 ilustra um exemplo de curva de desenvolvimento da massa, onde são indicados os parâmetros analisados: altura de desenvolvimento da massa $(H m)$, dado em mm e seu tempo correspondente $(T 1)$, dado em min.

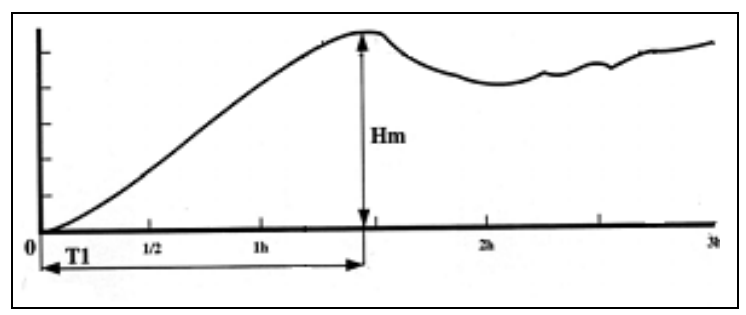

Figura 3-19. Curva típica de desenvolvimento da massa, obtida no reofermentógrafo CHOPIN. 
A Figura 3-20 é um exemplo de curva de retenção gasosa, onde são indicados os parâmetros analisados: altura relativa à pressão máxima $\left(H^{\prime} m\right)$ dado em $\mathrm{mm}$, seu tempo correspondente ( $\left.T^{\prime} 1\right)$ dado em min, tempo em que a massa começa a perder $\mathrm{CO}_{2}(T x)$ dado em min. $\mathrm{O}$ coeficiente de retenção do gás $\left(C_{r}\right)$ é calculado pelo equipamento através da razão entre o volume de gás retido (A1) e o total $(\mathrm{A} 1+\mathrm{A} 2)$, e é dado em porcentagem (\%). A2 corresponde ao volume de gás perdido.

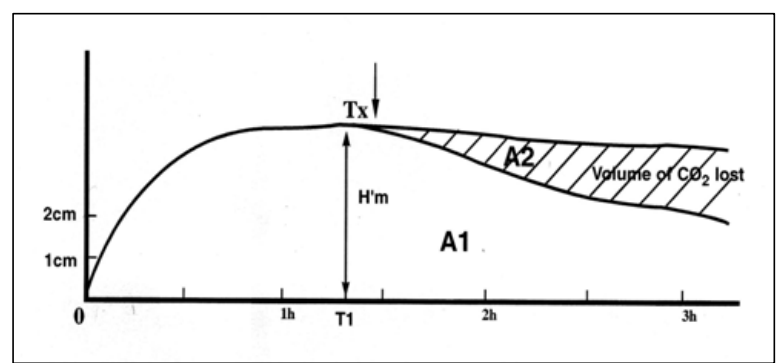

Figura 3-20. Curva típica de retenção gasosa, obtida no reofermentógrafo CHOPIN.

\subsubsection{Conteúdo de glúten úmido e seco}

As análises das misturas foram conduzidas em Glutomatic (Figura 3-21) (Perten Instruments, Suíça), conforme o método 38-12A da AACC (1995), realizadas no IDPC (Instituto do Desenvolvimento de Panificação e Confeitaria).

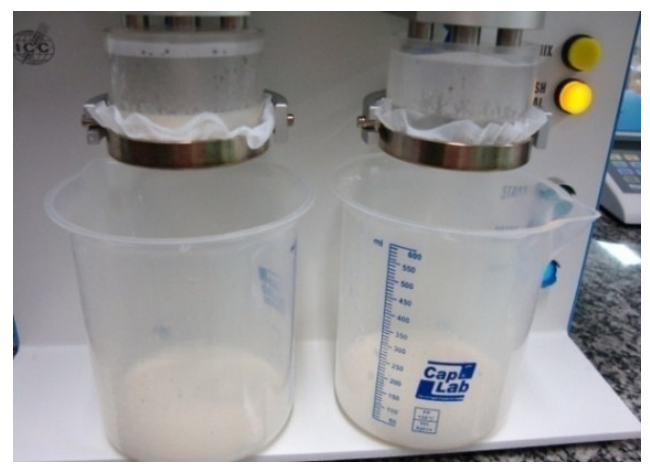

Figura 3-21. Glutomatic

As análises do conteúdo de glúten seco foram realizadas no Glutork (Perten Instruments, Suíça), onde a massa lavada no Glutomatic e centrifugada era prensada por 4 min em placas revestidas com teflon a $150{ }^{\circ} \mathrm{C}$ (Figura 3-22). 
Os parâmetros calculados foram: glúten úmido (dado em \%), glúten seco (dado em \%) e índice de glúten.

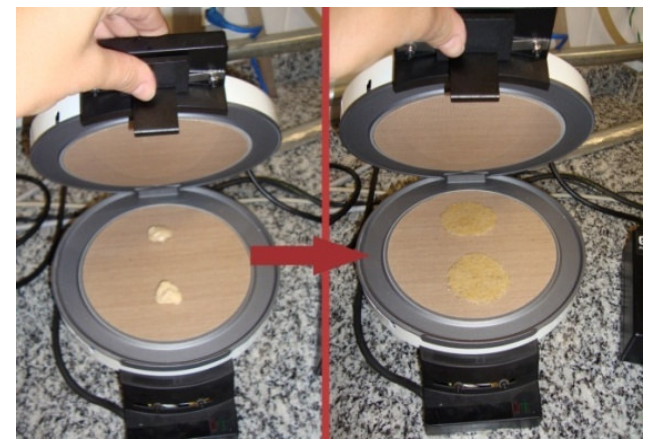

Figura 3-22. Glúten úmido e seco no Glutork.

\subsubsection{Farinografia}

Foram realizadas análises das misturas em farinógrafo (Brabender, Alemanha) de acordo com o método AACC 54-21, seguindo o procedimento de mistura constante, onde após a determinação do conteúdo de umidade, através da tabela AACC 82-23 determina-se a quantidade de mistura a ser pesada para que tenha $14 \%$ de umidade no final. Os parâmetros determinados foram: absorção de água (quando a massa atinge 500 U.F.), dado em \%; tempo de desenvolvimento da massa, dado em min; estabilidade, dado em min; índice de tolerância à mistura, dado em U.F. (Figura 3-23). As análises foram realizadas no laboratório do Moinho Anaconda, sob supervisão da Eng. Bruna Nascimento.

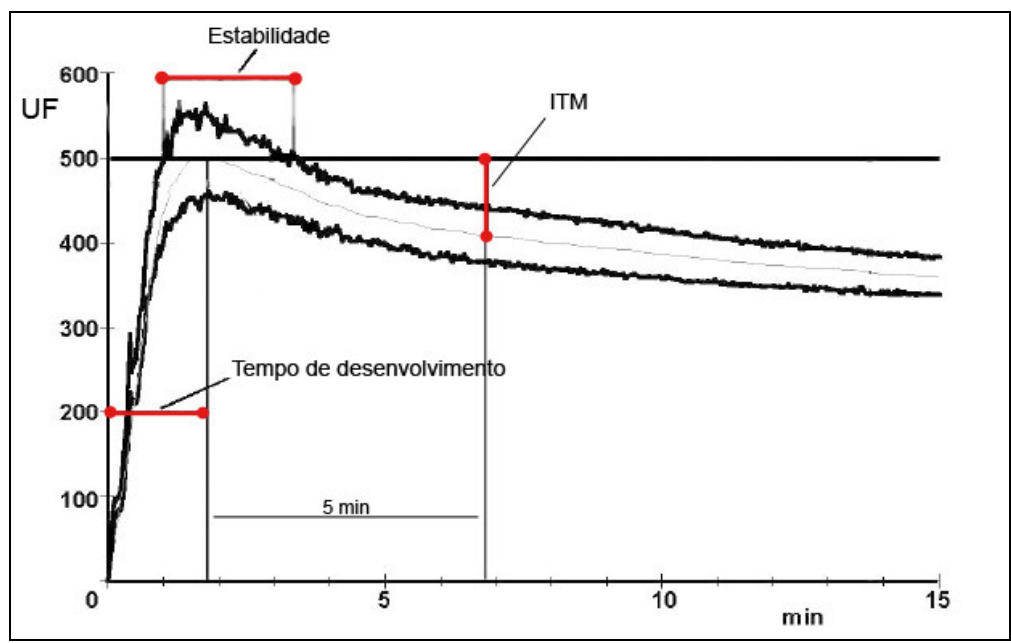

Figura 3-23. Exemplo de curva obtida no farinógrafo, indicando os parâmetros obtidos. 
3.2.11 Conteúdo de água (umidade)

Foi determinado o conteúdo de água das massas sem fermento, conforme o método de aquecimento direto em estufa (MARCONI, modelo MA-030, Brasil) a $130{ }^{\circ} \mathrm{C}$ (AACC 45-15, 1995).

\subsubsection{Cinzas}

Foi determinada a quantidade de cinzas das massas em quadruplicata, conforme método 08-03 da AACC (1995), utilizando um forno mufla (QUIMIS, modelo 25079, Brasil).

\subsection{Análise dos resultados}

ANOVA foi aplicada nos resultados e as diferenças significativas foram confirmadas pelo teste de Tukey, no intervalo de confiança de $95 \%$, utilizando o software Statgraphics Plus 4.0 (Manugistics ${ }^{\circledR}$ ). Diferenças significativas de cada efeito e interações foram obtidas e a metodologia de superfície resposta foi utilizada para otimização dos resultados. 


\section{$4 \quad$ RESULTADOS E DISCUSSÕES}

\subsection{Parâmetros de textura obtidos no teste de extensão uniaxial}

ANOVA foi executada no intervalo de confiança de $95 \%$ nos parâmetros obtidos no teste de extensão uniaxial: resistência à extensão $(F)$, extensibilidade na ruptura $(L)$ e energia aplicada à massa até a ruptura $(A)$.

Os ensaios foram conduzidos em aproximadamente 10 tiras de massa para cada formulação e na análise estatística foram consideradas réplicas. Foi aplicado o teste de Tukey nos parâmetros que apresentaram diferenças significativas na ANOVA, e nas Tabelas 4-1 e 4-2 estão apresentados os valores médios de $F, L$ e $A$ em função da substituição de FT por ARM e de $F$ em função da adição de TG, respectivamente.

Os efeitos dos parâmetros de textura foram avaliados individualmente, apesar de que todas as formulações foram preparadas conjuntamente com ARM e TG, conforme apresentado na Tabela 3-1.

Tabela 4-1. Valores médios da resistência à extensão $(F)$, extensibilidade na ruptura $(L)$ e energia aplicada à massa até a ruptura $(A)$ obtidos pelo teste de extensão uniaxial das massas de pão em função da porcentagem de substituição de farinha de trigo (FT) por amido resistente de milho (ARM).

\begin{tabular}{cccc}
\hline ARM $(\%)$ & $\boldsymbol{F}(\mathbf{m N})$ & $\boldsymbol{L}(\mathbf{m m})$ & $\boldsymbol{A}(\mathbf{N} \cdot \mathbf{m m})$ \\
\hline 0,0 & $499,7 \pm 37,6$ & $28,4 \pm 3,3$ & $16,3 \pm 1,7$ \\
\hdashline 1,5 & $550,8 \pm 28,2^{\mathrm{bc}^{\mathrm{c}}}$ & $30,4 \pm 2,6^{\mathrm{ab}}$ & $18,8 \pm 7,7^{\mathrm{a}}$ \\
3,5 & $444,7 \pm 19,0^{\mathrm{a}}$ & $40,9 \pm 1,7^{\mathrm{c}}$ & $18,5 \pm 5,2^{\mathrm{a}}$ \\
8,5 & $615,0 \pm 12,0^{\mathrm{c}}$ & $23,5 \pm 1,1^{\mathrm{a}}$ & $16,0 \pm 3,3^{\mathrm{b}}$ \\
13,5 & $498,7 \pm 19,0^{\mathrm{ab}}$ & $29,1 \pm 1,7^{\mathrm{ab}}$ & $15,9 \pm 5,2^{\mathrm{b}}$ \\
15,5 & $432,2 \pm 26,9^{\mathrm{a}}$ & $33,5 \pm 2,5^{\mathrm{bc}}$ & $14,9 \pm 7,4^{\mathrm{b}}$ \\
\hline DMS & 107,9 & 9,8 & 2,1 \\
\hline
\end{tabular}

Médias na mesma coluna com a mesma letra não são significativamente diferentes $(p>0,05)$

DMS: diferença mínima significativa 
Tabela 4-2. Valores médios da resistência à extensão $(F)$, determinada pelo teste uniaxial das massas de pão em função da porcentagem de adição de enzima transglutaminase (TG).

\begin{tabular}{cc}
\hline TG $(\%)$ & $\boldsymbol{F}(\mathbf{m N})$ \\
\hline 0,00 & $499,7 \pm 37,6$ \\
\hdashline 0,03 & $493,6 \pm 29,3^{\mathrm{a}}$ \\
0,05 & $442,5 \pm 20,7^{\mathrm{a}}$ \\
0,10 & $583,8 \pm 13,2^{\mathrm{b}}$ \\
0,15 & $500,8 \pm 20,7^{\mathrm{a}}$ \\
0,17 & $648,4 \pm 29,3^{\mathrm{b}}$ \\
\hline DMS & 115,0
\end{tabular}

Médias na mesma coluna com a mesma letra não são significativamente diferentes $(p>0,05)$

DMS: diferença mínima significativa

A Figura 4-1 mostra os efeitos principais causados pela substituição de ARM e adição de TG nos parâmetros do teste de extensão uniaxial da massa de pão. A análise estatística indicou que a TG não influenciou significativamente $(p>0,05)$ a extensibilidade na ruptura $(L)$ e a energia aplicada à massa $(A)$, porém influenciou a resistência à extensão $(F)$. Até a adição de $0,05 \%$ de TG, não foi observada diferença em relação ao controle.

Observou-se uma tendência de aumento de $F$ com a adição de TG, de forma similar ao encontrado por Basman, Köksel e $\mathrm{Ng}$ (2002), que analisaram adições da enzima transglutaminase no intervalo $(0$ - 1,5) \% (base mistura) em dois tipos de farinha de trigo proveniente dos Estados Unidos. Por outro lado, esses autores constataram um decréscimo significativo de $L$ no intervalo estudado, diferentemente desse trabalho, que não apresentou diferença significativa no intervalo menor entre $(0,03-0,17) \%$ (base mistura).

Quando adicionada de 9,6 \% de ARM, a extensibilidade na ruptura $(L)$ da massa atingiu o valor mínimo (22\% menor que o controle). A energia aplicada à massa até ruptura diminuiu com o aumento de ARM. 

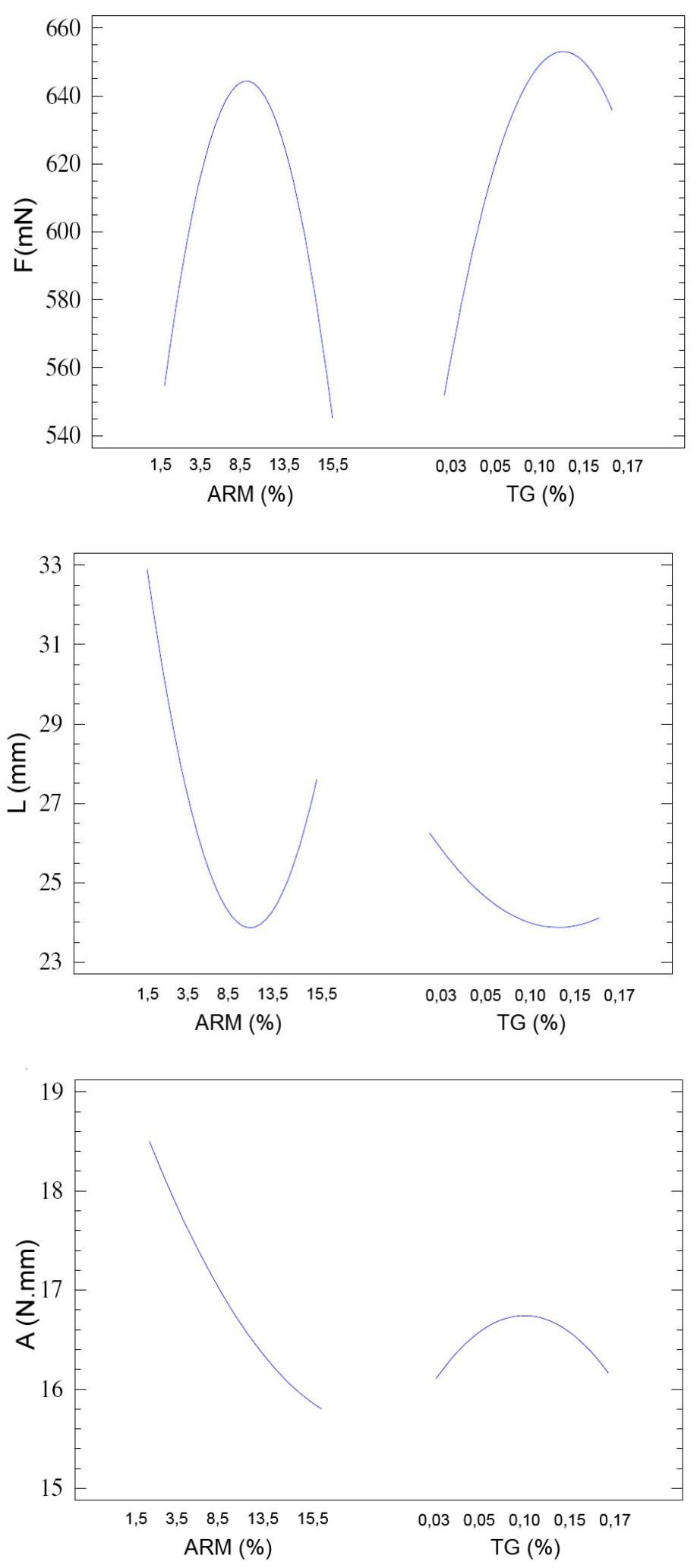

Figura 4-1. Efeitos principais causados pela substituição por amido resistente de milho (ARM) e adição da enzima transglutaminase (TG) nos parâmetros resistência à extensão $(F)$, extensibilidade na ruptura $(L)$ e energia aplicada à massa até a ruptura $(A)$, obtidos do teste de extensão uniaxial da massa de pão. 
A resistência a extensão $(F)$ atingiu o valor máximo em torno de $650 \mathrm{mN}$ (32\% maior que a do controle) nos níveis $0,12 \%$ e $8,4 \%$ de TG e ARM, respectivamente, conforme a superfície de resposta estimada, mostrada na Figura 4-2.

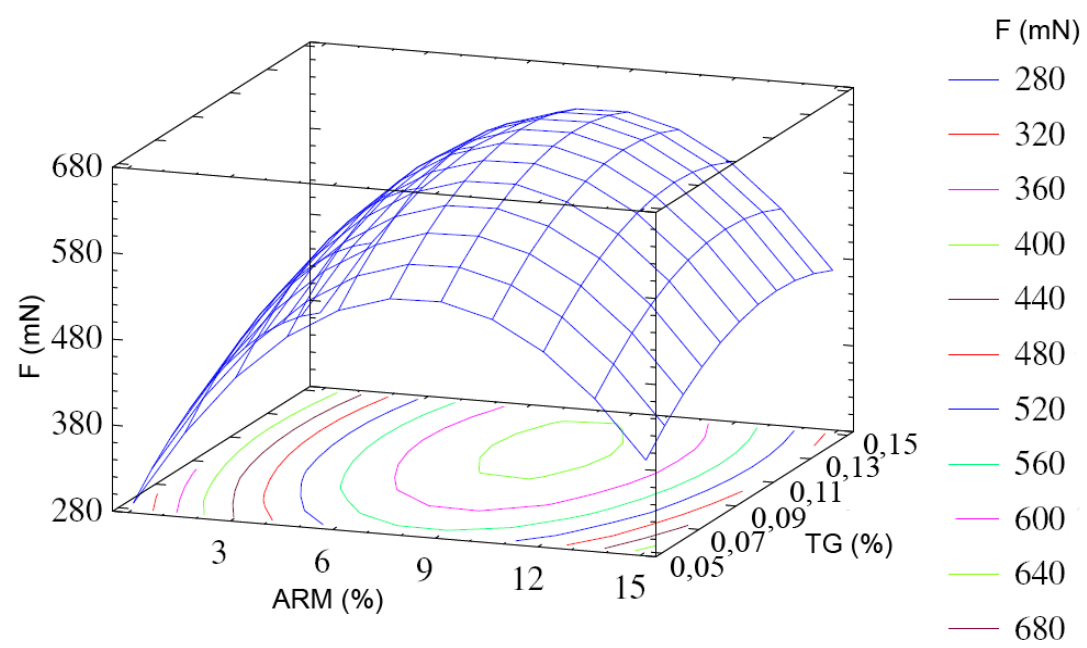

Figura 4-2. Superfície de resposta para a resistência à extensão $(F)$ obtida do teste de extensão uniaxial, conforme substituição de farinha de trigo (FT) por amido resistente de milho (ARM) e adição da enzima transglutaminase (TG).

\subsection{Parâmetros de textura obtidos no teste biaxial}

ANOVA foi executada no intervalo de confiança de $95 \%$ nos parâmetros obtidos no teste de extensão biaxial: tenacidade $(P)$, extensibilidade $(L)$, energia de deformação da massa $(W)$ e a razão $P / L$.

Os resultados mostraram que o ARM não influenciou significativamente $(p>0,05)$ a energia de deformação da massa obtida pela extensão biaxial, enquanto que a adição de TG não influenciou significativamente ( $p>0,05)$ a tenacidade, a extensibilidade e a razão $P / L$. A tenacidade indica a habilidade da massa de reter 0 gás produzido na fermentação.

Os efeitos dos parâmetros de textura foram avaliados individualmente, apesar de que todas as formulações foram preparadas conjuntamente com ARM e TG, conforme apresentado na Tabela 3-1. Esses valores são apresentados nas Tabelas 4-3 e 4-4.

O aumento da razão $P / L$ com a substituição de FT por ARM é decorrente do aumento da tenacidade $(P)$ e diminuição da extensibilidade $(L)$. Foi possível observar que os valores de $P$ e $L$ se alternam gerando uma energia de deformação da 
massa $(W)$, que é calculada pela área sob a curva obtida, constante em relação à substituição de FT por ARM.

Tabela 4-3. Valores médios da tenacidade $(P)$, extensibilidade $(L)$ e da razão $P / L$ obtidos do teste biaxial das massas de pão em função da porcentagem de substituição de farinha de trigo (FT) por amido resistente de milho (ARM).

\begin{tabular}{|c|c|c|c|}
\hline ARM (\%) & $P\left(\mathrm{~mm} \mathrm{H}_{2} \mathrm{O}\right)$ & $L(\mathrm{~mm})$ & $\overline{P / L}$ \\
\hline 0,0 & $204,6 \pm 5,8$ & $114,3 \pm 38,0$ & $2,0 \pm 0,8$ \\
\hline 1,5 & $217,5 \pm 13,6^{a a^{0}}$ & $96,0 \pm 10,2^{6-}$ & $2,4 \pm 0,5^{a b^{-}}$ \\
\hline 3,5 & $202,8 \pm 9,1^{\mathrm{a}}$ & $90,0 \pm 6,8^{b}$ & $2,4 \pm 0,3^{\mathrm{a}}$ \\
\hline 8,5 & $226,0 \pm 5,5^{\mathrm{ab}}$ & $78,8 \pm 4,1^{\mathrm{ab}}$ & $3,1 \pm 0,2^{\mathrm{ab}}$ \\
\hline 13,5 & $250,9 \pm 8,6^{b c}$ & $58,4 \pm 6,4^{\mathrm{a}}$ & $4,5 \pm 0,3^{c}$ \\
\hline 15,5 & $280,4 \pm 12,2^{c}$ & $73,8 \pm 9,1^{\mathrm{ab}}$ & $4,3 \pm 0,5^{\mathrm{bc}}$ \\
\hline DMS & 51,9 & 34,7 & 2,0 \\
\hline
\end{tabular}

Médias na mesma coluna com a mesma letra não são significativamente diferentes $(p>0,05)$

DMS: diferença mínima significativa

Tabela 4-4. Valores médios da energia de deformação da massa ( $W$ ) obtidos do teste biaxial das massas de pão em função da porcentagem de adição da enzima transglutaminase (TG).

\begin{tabular}{cc}
\hline TG (\%) & $\boldsymbol{W ( \mathbf { 1 0 } ^ { - 4 } \mathbf { J } )}$ \\
\hline 0,00 & $580,9 \pm 139,4$ \\
\hdashline 0,03 & $525,8 \pm 41,1^{\mathrm{a}}$ \\
0,05 & $524,7 \pm 30,7^{\mathrm{ab}}$ \\
0,10 & $582,3 \pm 18,8^{\mathrm{ab}}$ \\
0,15 & $459,7 \pm 29,1^{\mathrm{ab}}$ \\
0,17 & $489,0 \pm 41,1^{\mathrm{b}}$ \\
\hline DMS & 165,0
\end{tabular}

Médias na mesma coluna com a mesma letra não são significativamente diferentes $(p>0,05)$

DMS: diferença mínima significativa

A tenacidade $(P)$ aumentou $37 \%$ e a extensibilidade $(L)$ diminuiu $35 \%$, obtidas da extensão biaxial da massa adicionada de ARM, quando comparadas com as do controle (205 $\mathrm{mm} \mathrm{H} \mathrm{H}_{2} \mathrm{O}$ e $114 \mathrm{~mm}$, respectivamente).

A Figura 4-3 mostra que o valor de $P$ aumentou com a adição de ARM, de forma similar ao encontrado por Wang, Rosell e Barber (2002), que estudaram o desempenho da massa de farinha de trigo adicionada de diversos tipos de fibras. Além disso, esses autores também relataram que as fibras reduziram a extensibilidade da massa $(L)$. 
Entretanto, a adição de TG influenciou significativamente $(p<0,05)$ apenas a energia de deformação da massa $(W)$, apresentando um pico máximo de $550 \times 10^{-4} \mathrm{~J}$ (6 \% abaixo do controle) quando $0,08 \%$ de TG foi adicionada.
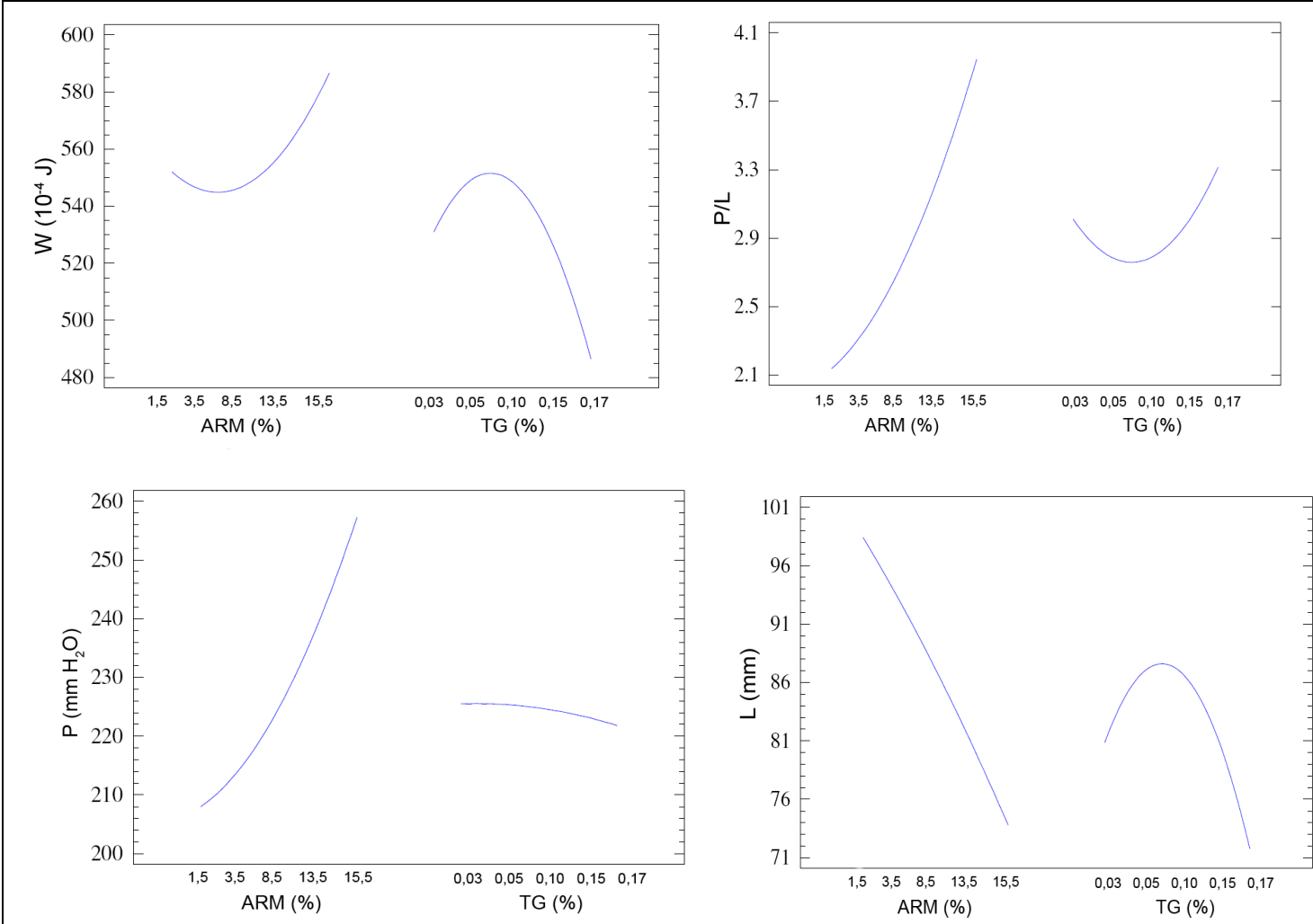

Figura 4-3. Efeitos principais causados pela substituição de farinha de trigo (FT) por amido resistente de milho (ARM) e adição da enzima transglutaminase (TG) nos parâmetros energia de deformação da massa (W), $P / L$, tenacidade $(P)$ e extensibilidade $(L)$ obtidos do teste de extensão biaxial da massa de pão.

\subsection{Parâmetros de textura obtidos das curvas de TPA (Texture Profile Analysis)}

Na Tabela 4-6 estão apresentados os valores médios dos parâmetros obtidos no teste TPA. Os efeitos dos parâmetros de textura foram avaliados individualmente, apesar de que todas as formulações foram preparadas conjuntamente com ARM e TG, conforme apresentado na Tabela 3-1. 
Tabela 4-5. Parâmetros obtidos da TPA (Texture Profile Analysis) em função da substituição de farinha de trigo (FT) por amido resistente de milho (ARM) e da adição da transglutaminase (TG) nas massas.

\begin{tabular}{ccccccc}
\hline ARM (\%) & TG (\%) & $\begin{array}{c}\text { Dureza } \\
\text { (N) }\end{array}$ & $\begin{array}{c}\text { Adesividade } \\
\text { (N.s) }\end{array}$ & Elasticidade & Coesividade & Resiliência \\
\hline 0,0 & 0,00 & $81,9 \pm 1,9$ & $-128,0 \pm 34,9$ & $0,992 \pm 0,007$ & $0,61 \pm 0,07$ & $0,079 \pm 0,001$ \\
\hline $3,5^{\prime} \cdots$ & 0,05 & $99,6 \pm 3,4$ & $-53,3 \pm 0,2$ & $0,982 \pm 0,016$ & $0,43 \pm 0,02$ & $0,090 \pm 0,002$ \\
13,5 & 0,05 & $107,0 \pm 3,6$ & $-80,5 \pm 12,7$ & $0,985 \pm 0,004$ & $0,44 \pm 0,01$ & $0,090 \pm 0,001$ \\
3,5 & 0,15 & $94,6 \pm 3,4$ & $-63,8 \pm 5,8$ & $0,987 \pm 0,001$ & $0,45 \pm 0,01$ & $0,084 \pm 0,000$ \\
13,5 & 0,15 & $102,8 \pm 8,4$ & $-127,3 \pm 72,0$ & $0,990 \pm 0,019$ & $0,55 \pm 0,16$ & $0,086 \pm 0,001$ \\
8,5 & 0,10 & $101,1^{*}$ & $-73,6^{*}$ & $0,982^{*}$ & $0,48^{*}$ & $0,087^{*}$ \\
8,5 & 0,10 & $106,7 \pm 5,0$ & $-90,9 \pm 29,5$ & $0,986 \pm 0,005$ & $0,49 \pm 0,00$ & $0,091 \pm 0,004$ \\
8,5 & 0,10 & $122,1 \pm 3,0$ & $-60,6 \pm 8,2$ & $0,986 \pm 0,001$ & $0,45 \pm 0,02$ & $0,097 \pm 0,002$ \\
1,5 & 0,10 & $79,7 \pm 1,9$ & $-116,1 \pm 45,0$ & $0,995 \pm 0,002$ & $0,54 \pm 0,12$ & $0,075 \pm 0,004$ \\
8,5 & 0,17 & $103,5 \pm 3,5$ & $-79,6 \pm 38,7$ & $0,986 \pm 0,005$ & $0,44 \pm 0,04$ & $0,088 \pm 0,001$ \\
15,5 & 0,10 & $117,9 \pm 3,5$ & $-87,8 \pm 6,9$ & $0,992 \pm 0,000$ & $0,45 \pm 0,00$ & $0,094 \pm 0,001$ \\
8,5 & 0,03 & $87,1 \pm 6,5$ & $-97,4 \pm 4,3$ & $0,992 \pm 0,001$ & $0,47 \pm 0,02$ & $0,085 \pm 0,004$ \\
\hline
\end{tabular}

*Perda da 2a amostra.

ANOVA foi executada no intervalo de confiança de 95 \%os parâmetros de dureza, elasticidade, resiliência, coesividade e adesividade das massas de pão, e na Tabela 4-6 estão mostrados os valores dureza e resiliência, parâmetros que foram influenciados significativamente pela substituição de FT por ARM. No entanto, os parâmetros coesividade, adesividade e elasticidade não foram influenciados significativamente $(p>0,05)$ nem pela substituição parcial da FT por ARM e nem pela adição de TG, no intervalo estudado. A adição da TG não influenciou significativamente $(p>0,05)$ a resiliência e a dureza determinadas pelo TPA.

Tabela 4-6. Valores médios de dureza e resiliência obtidos no teste de TPA de acordo com a substituição de farinha de trigo (FT) por amido resistente de milho (ARM).

\begin{tabular}{ccc}
\hline ARM (\%) & Dureza (N) & Resiliência \\
\hline 0,0 & $81,9 \pm 1,9$ & $0,08 \pm 0,00$ \\
\hline 1,5 & $79,7 \pm 6,8^{\mathrm{a}^{\mathrm{a}}}$ & $0,08 \pm 0,00^{\mathrm{a}}$ \\
3,5 & $97,1 \pm 4,9^{\mathrm{ab}}$ & $0,09 \pm 0,00^{\mathrm{b}}$ \\
8,5 & $104,2 \pm 3,2^{\mathrm{b}}$ & $0,09 \pm 0,00^{\mathrm{b}}$ \\
13,5 & $104,9 \pm 4,9^{\mathrm{ab}}$ & $0,09 \pm 0,00^{\mathrm{b}}$ \\
15,5 & $117,9 \pm 6,9^{\mathrm{b}}$ & $0,09 \pm 0,00^{\mathrm{b}}$ \\
\hline DMS & 29,8 & 0,01
\end{tabular}

Médias na mesma coluna com a mesma letra não são significativamente diferentes ( $p>0,05)$

DMS: diferença mínima significativa 
Collar e Bollaín (2004) reportaram que a coesividade da massa é um bom parâmetro para predizer o frescor do pão. Entretanto, pão de forma formulado com farinha de trigo parcialmente substituída por ARM e adicionado de TG aos níveis estudados neste trabalho, provavelmente não apresentarão diferenças perceptíveis de textura por parte dos consumidores.

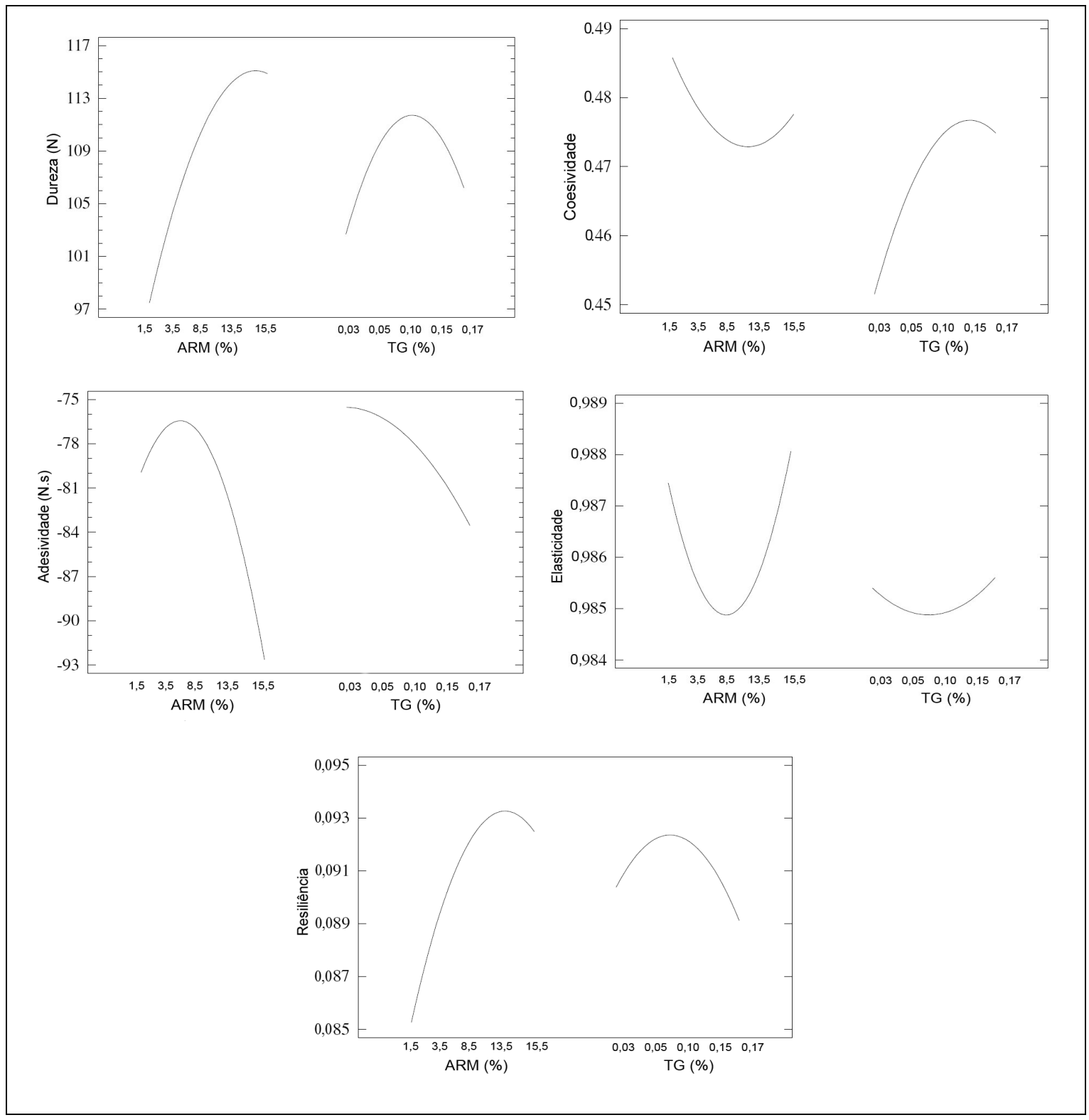

Figura 4-4. Efeitos principais causados pela substituição de amido resistente de milho (ARM) e adição da enzima transglutaminase (TG) nos parâmetros dureza, coesividade, adesividade, elasticidade e resiliência obtidos do teste de TPA (Texture Profile Analysis) da massa de pão.

Observa-se na Figura 4-4 que a coesividade e a elasticidade não foram influenciadas pela adição de TG (até 0,17 \% base mistura), diferentemente do 
resultado apresentado por Collar e Bollaín (2004) que quando adicionaram 0,422 \% de TG (base farinha), observaram que a coesividade aumentou $2 \%$ e a elasticidade 1 \% em relação ao controle. Embora não tenha apresentado diferença significativa, a coesividade mostrou uma tendência de crescimento com a adição de TG.

A dureza da massa aumentou com o aumento da substituição do ARM, mostrando um valor de 40 \% superior em relação ao controle $(81,9 \mathrm{~N})$ quando na máxima substituição.

Baseado nos testes de textura realizados observou-se um efeito antagônico na substituição de FT por ARM, já que até aproximadamente $10 \%$ de substituição por ARM aumentou a resistência à extensão e a dureza, e para valores maiores, devido a diluição do glúten, a massa ficou enfraquecida, perdendo força e dureza.

Ambos os parâmetros de extensibilidade obtidos nos testes de extensão uniaxial e biaxial apresentaram uma tendência de queda com a substituição por ARM.

A TG influenciou apenas dois dos doze parâmetros de textura avaliados, sendo eles: resistência à extensão e energia de deformação da massa, porém nos níveis estudados não foi encontrado o resultado esperado para que compensasse a diferença nos parâmetros causado pelo ARM na massa de pão.

\subsection{Análises de Calorimetria Exploratória Diferencial (DSC)}

Além das análises nas massas, foram também realizados ensaios com suspensões de FT e o ARM separadamente, com diferentes quantidades de água, apenas para caracterizá-las. Foi possível comparar o comportamento do pico de fusão para as diferentes quantidades de água. Quanto maior a quantidade de água, maior a entalpia de fusão foi encontrada, como esperado (Figura 4-5). À $20{ }^{\circ} \mathrm{C}$ observa-se um degrau, causado pela aumento da taxa de aquecimento. 


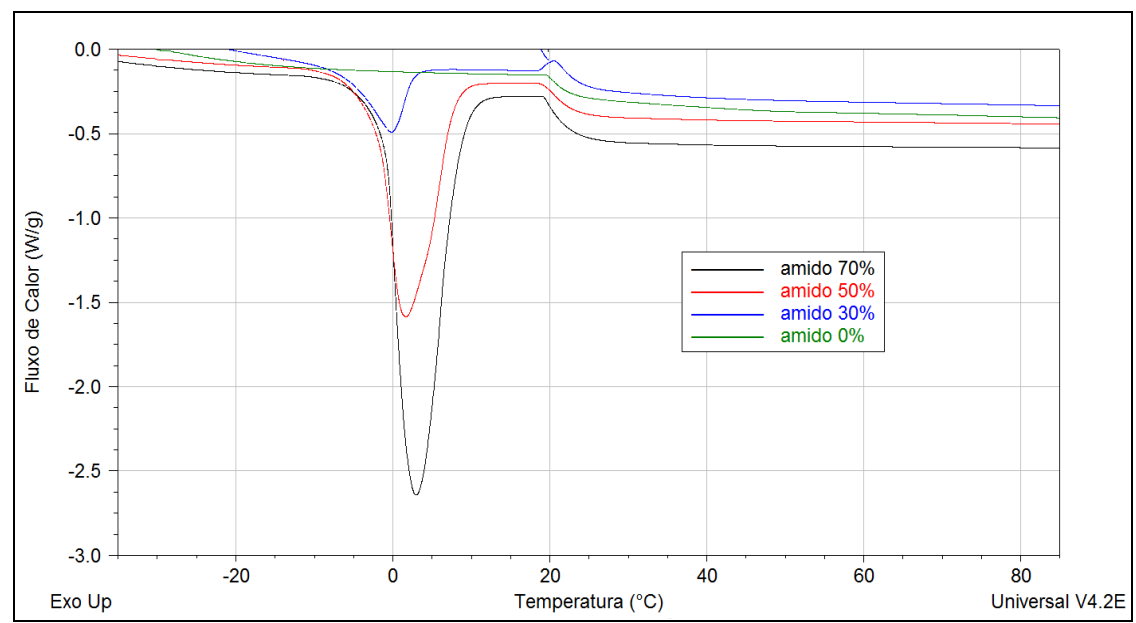

Figura 4-5. Termogramas de suspensões de amido resistente de milho (ARM) com diferentes quantidades de água, indicando o evento de fusão da água.

A partir dos termogramas obtidos da FT (Figura 4-6) pode-se observar o pico de entalpia de gelatinização do amido de trigo em temperaturas próximas de $60{ }^{\circ} \mathrm{C}$, como esperado. Para baixas quantidades de água ((0 e 30) \%), não foi possível observar claramente esse pico, já que não havia água suficiente para a gelatinização do amido.

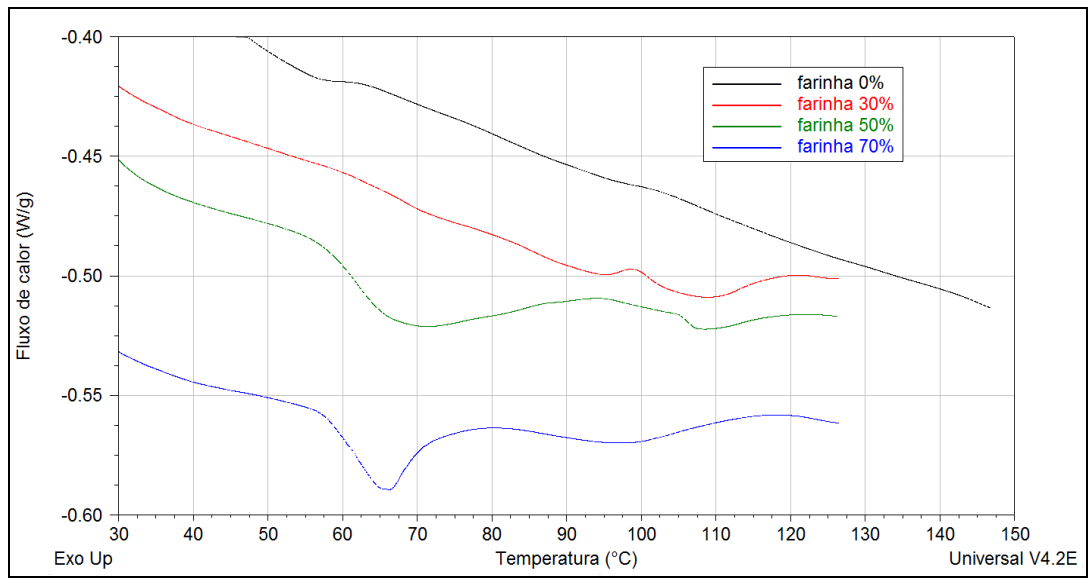

Figura 4-6. Termogramas de suspensões de farinha de trigo (FT) com diferentes quantidades de água, indicando o evento da gelatinização do amido.

Nos termogramas do ARM (Figura 4-7), pode notar que o evento de gelatinização do amido se apresenta de forma diferente a da farinha de trigo, e em temperaturas próximas de $115^{\circ} \mathrm{C}$. Observa-se que quanto maior a quantidade de água, mais nítido é o pico da gelatinização do ARM. De fato, para que ocorra a gelatinização, é necessário que haja água para intumescer o grânulo de amido, por 
isso que a curva obtida na amostra de ARM seco (sem adição de água) não apresenta picos.

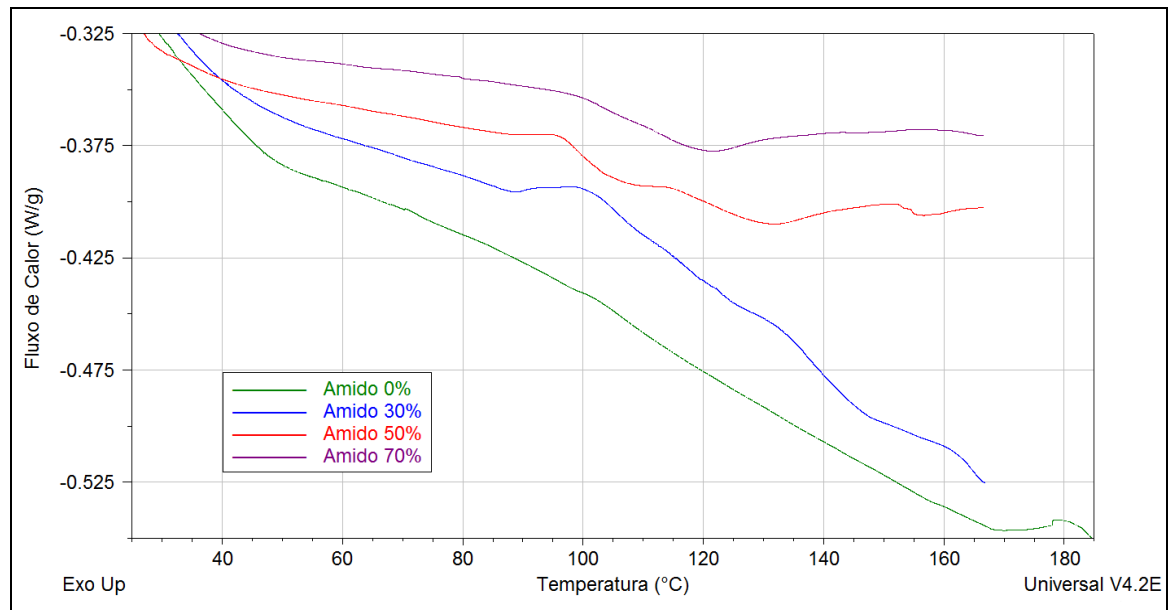

Figura 4-7. Termogramas de suspensão do amido resistente de milho (ARM) com diferentes quantidades de água, indicando o evento da gelatinização do ARM.

Os valores obtidos através das curvas do DSC das massas são mostrados nas Tabelas 4-7, 4-8 e 4-9.

Tabela 4-7. Temperatura onset $\left(T_{\text {onset }}\right)$, entalpia de fusão $\left(\Delta_{\text {fus }} H\right)$, fração de água congelável ( $F W$ e fração de água não-congelável (UFW), calculados do pico de entalpia de fusão da água, nas massas produzidas com diferentes quantidades de amido resistente de milho (ARM) e da adição da transglutaminase (TG).

\begin{tabular}{cccccc}
\hline ARM (\%) & TG (\%) & $\boldsymbol{T}_{\text {onset }}\left({ }^{\circ} \mathbf{C}\right)$ & $\boldsymbol{\Delta}_{\text {fus }} \boldsymbol{H}(\mathrm{J} / \mathrm{g}$ massa seca) & $\boldsymbol{F W}(\%)$ & $\boldsymbol{U} \boldsymbol{W}(\%)$ \\
\hline 0,0 & 0,00 & $-7,87$ & $-137,58$ & 0,60 & 0,40 \\
\hdashline 3,5 & 0,05 & $-7,06$ & $-150,68$ & 0,61 & 0,39 \\
13,5 & 0,05 & $-6,70$ & $-153,72$ & 0,60 & 0,40 \\
3,5 & 0,15 & $-6,45$ & $-145,6$ & 0,56 & 0,44 \\
13,5 & 0,15 & $-7,60$ & $-162,82$ & 0,67 & 0,33 \\
8,5 & 0,10 & $-6,54$ & $-153,59$ & 0,59 & 0,41 \\
8,5 & 0,10 & $-6,10$ & $-150,41$ & 0,60 & 0,40 \\
8,5 & 0,10 & $-6,79$ & $-153,11$ & 0,61 & 0,39 \\
1,5 & 0,10 & $-7,24$ & $-159,83$ & 0,61 & 0,39 \\
8,5 & 0,17 & $-6,66$ & $-147,86$ & 0,61 & 0,39 \\
15,5 & 0,10 & $-6,80$ & $-152,06$ & 0,62 & 0,38 \\
8,5 & 0,03 & $-6,61$ & $-112,99$ & 0,51 & 0,49 \\
\hline
\end{tabular}


Tabela 4-8. Temperatura onset $\left(\mathrm{T}_{\text {onset }}\right)$, entalpia de gelatinização $(\Delta H)$, calculados do pico de entalpia de gelatinização do amido de trigo, nas massas produzidas com diferentes quantidades de amido resistente de milho (ARM) e da adição da transglutaminase (TG).

\begin{tabular}{cccc}
\hline ARM (\%) & TG (\%) & $\boldsymbol{T}_{\text {onset }}\left({ }^{\circ} \mathbf{C}\right)$ & $\boldsymbol{\Delta}_{\text {fus }} \boldsymbol{H}(\mathrm{J} / \mathbf{g}$ massa seca) \\
\hline 0,0 & 0,00 & 61,80 & $-6,46$ \\
\hline 3,5 & 0,05 & 63,35 & $-6,54$ \\
13,5 & 0,05 & 60,80 & $-6,79$ \\
3,5 & 0,15 & 60,33 & $-7,94$ \\
13,5 & 0,15 & 62,82 & $-7,72$ \\
8,5 & 0,10 & 62,85 & $-5,55$ \\
8,5 & 0,10 & 61,07 & $-6,53$ \\
8,5 & 0,10 & 61,47 & $-6,73$ \\
1,5 & 0,10 & 60,96 & $-9,30$ \\
8,5 & 0,17 & 62,63 & $-6,36$ \\
15,5 & 0,10 & 61,80 & $-5,76$ \\
8,5 & 0,03 & 61,26 & $-4,85$ \\
\hline
\end{tabular}

Tabela 4-9. Temperatura onset $\left(T_{\text {onset }}\right)$ e entalpia de gelatinização $(\Delta H)$ calculados do pico de entalpia de gelatinização do ARM, nas massas produzidas com diferentes quantidades de amido resistente de milho (ARM) e da adição da transglutaminase (TG).

\begin{tabular}{cccc}
\hline ARM (\%) & TG (\%) & $\boldsymbol{T}_{\text {onset }}\left({ }^{\circ} \mathbf{C}\right)$ & $\boldsymbol{\Delta} \boldsymbol{H}(\mathbf{J} / \mathbf{g}$ massa seca) \\
\hline 0,0 & 0,00 & 108,26 & $-1,16$ \\
\hline 3,5 & 0,05 & 107,31 & $-1,15$ \\
13,5 & 0,05 & 107,01 & $-0,69$ \\
3,5 & 0,15 & 112,05 & $-2,07$ \\
13,5 & 0,15 & 108,26 & $-0,69$ \\
8,5 & 0,10 & 106,28 & $-0,88$ \\
8,5 & 0,10 & 119,41 & $-1,03$ \\
8,5 & 0,10 & 106,28 & $-1,03$ \\
1,5 & 0,10 & 107,21 & $-1,36$ \\
8,5 & 0,17 & 107,17 & $-0,91$ \\
15,5 & 0,10 & 104,84 & $-0,87$ \\
8,5 & 0,03 & 105,99 & $-0,89$ \\
\hline
\end{tabular}

ANOVA foi executada no intervalo de confiança de $95 \%$ nos parâmetros obtidos das curvas do DSC para cada pico observado: Temperatura onset ( $\left.T_{\text {onset }}\right)$ e Entalpia $(\Delta H)$; e para o pico de fusão da água: Fração de água congelável $(F W)$ e Fração de água não-congelável (UFW). 
Foi aplicado o teste de Tukey nos parâmetros que apresentaram diferenças significativas para determinar a diferença entre as médias. Esses efeitos dos parâmetros do DSC foram avaliados individualmente, apesar de que todas as formulações foram preparadas conjuntamente com ARM e TG, conforme apresentado na Tabela 3-1.

Para o pico de fusão da água e o pico de gelatinização do amido de trigo, nenhum dos parâmetros apresentou diferença significativa. Isto é, a alteração na formulação não alterou as características do pico endotérmico de fusão da água e do pico de gelatinização no intervalo estudado. Quando comparado com o controle, também não se observou diferença. Os parâmetros $F W$ e UFW são úteis na determinação da temperatura de conservação de alimentos congelados.

Conforme informações do fabricante e análises de suspensões realizadas anteriormente, a temperatura de gelatinização do ARM ocorre entre $115{ }^{\circ} \mathrm{C}$ e $120{ }^{\circ} \mathrm{C}$, portanto é possível inferir que o $3^{\circ}$ pico de entalpia apresentado nas curvas, seja o da gelatinização do ARM.

Embora a entalpia de gelatinização do ARM não tenha apresentado diferença significativa, mostra uma tendência decrescente com o aumento da substituição de FT por ARM. Da mesma forma, a Tonset mostra um efeito decrescente com o aumento de ARM (Figura 4-8), pois quanto maior a quantidade de ARM, menor será a temperatura em que começará o evento de gelatinização do ARM.

Ainda assim, com 15,5 \% de substituição de FT por ARM, há a constatação de que esse amido adicionado só gelatinizaria a temperaturas maiores que $100{ }^{\circ} \mathrm{C}$, garantindo que não ocorresse gelatinização durante $\mathrm{o}$ assamento, o que tiraria a função do ARM no pão.

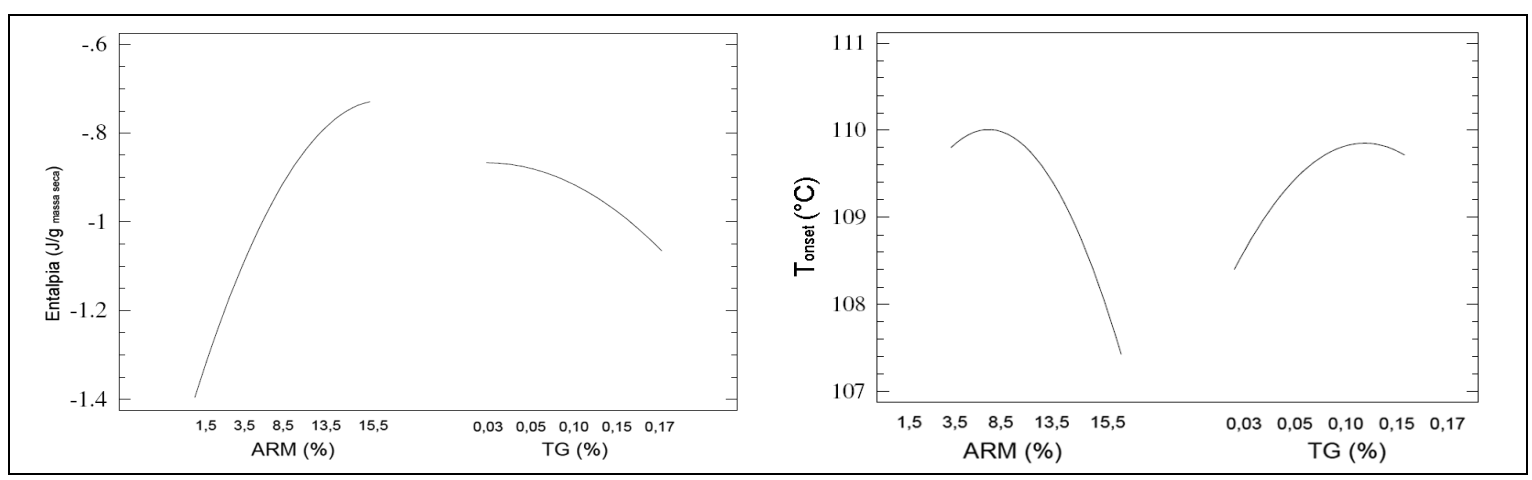

Figura 4-8. Efeitos principais causados pela substituição de farinha de trigo (FT) por amido resistente de milho (ARM) e adição da enzima transglutaminase (TG) na entalpia $(\Delta H)$ de gelatinização do ARM e na $T_{\text {onset }}$. 


\subsection{Reofermentógrafo}

$\mathrm{Na}$ Tabela 4-10 encontram-se todos os dados obtidos das curvas de desenvolvimento da massa e a de retenção gasosa do reofermentógrafo: altura máxima de desenvolvimento da massa $(H m)$ e seu tempo correspondente $(T 1)$, altura relativa à pressão máxima $\left(H^{\prime} m\right)$ e seu tempo correspondente $\left(T^{\prime} 1\right)$, tempo em que a massa começa a perder $\mathrm{CO}_{2}(T x)$ e coeficiente de retenção do gás $\left(C_{r}\right)$.

Tabela 4-10. Valores obtidos das curvas do reofermentógrafo, conforme substituição de farinha de trigo (FT) por amido resistente de milho (ARM) e adição da enzima transglutaminase (TG).

\begin{tabular}{cccccccc}
\hline ARM (\%) & TG (\%) & $\boldsymbol{H m}(\mathbf{m m})$ & $\boldsymbol{T 1}(\mathbf{m i n})$ & $\boldsymbol{H}^{\prime} \boldsymbol{m}(\mathbf{m m})$ & $\boldsymbol{T}^{\prime} \mathbf{1}(\mathbf{m i n})$ & $\boldsymbol{T x}(\mathbf{m i n})$ & $\boldsymbol{C}_{\boldsymbol{r}}(\%)$ \\
\hline 0,0 & 0,00 & 45,2 & 163,5 & 54,4 & 136,5 & 88,5 & 93,8 \\
\hdashline 3,5 & 0,05 & 42,1 & 1778,5 & 59,9 & 123,0 & 90,0 & 89,5 \\
13,5 & 0,05 & 34,6 & 177,0 & 62,7 & 114,0 & 67,5 & 86,5 \\
3,5 & 0,15 & 40,6 & 177,0 & 53,8 & 148,5 & 114,0 & 94,6 \\
13,5 & 0,15 & 33,9 & 175,5 & 67,9 & 175,5 & 97,5 & 95,2 \\
8,5 & 0,10 & 36,7 & 159,0 & 58,1 & 126,0 & 90,0 & 89,9 \\
8,5 & 0,10 & 40,3 & 175,5 & 62,6 & 91,5 & 81,0 & 85,3 \\
8,5 & 0,10 & 38,7 & 175,5 & 69,8 & 177,0 & 102,0 & 97,2 \\
1,5 & 0,10 & 41,2 & 175,5 & 62,6 & 106,5 & 75,0 & 83,9 \\
8,5 & 0,17 & 38,2 & 180,0 & 65,3 & 112,5 & 73,5 & 83,2 \\
15,5 & 0,10 & 32,2 & 178,5 & 60,8 & 111,0 & 82,5 & 86,6 \\
8,5 & 0,03 & 36,7 & 163,5 & 67,0 & 91,5 & 69,0 & 82,6
\end{tabular}

ANOVA foi executada no intervalo de confiança de $95 \%$ nos parâmetros obtidos das curvas do reofermentógrafo e indicou que os parâmetros $T 1, H^{\prime} m$, T'1, $T x$ e $C_{r}$ não foram influenciados significativamente $(p>0,05)$ pela substituição parcial da farinha de trigo por ARM e adição de TG no intervalo estudado. De acordo com o estudo realizado por Matsuda (2007), esses parâmetros também não foram influenciados em um estudo em que a farinha de trigo foi substituída por ARM no nível entre (0 e 30) \%.

O efeito da substituição parcial de farinha de trigo por ARM sobre o parâmetro $\mathrm{Hm}$ obtido da curva do reofermentógrafo, foi o único que apresentou diferença significativa $(p<0,05)$, e portanto foi avaliado individualmente, apesar de que todas 
as formulações foram preparadas conjuntamente com ARM e TG (Tabela 3-1). Conforme se aumentou a quantidade de ARM na massa, o $\mathrm{Hm}$ reduziu (Tabela 4-11).

Tabela 4-11. Altura de desenvolvimento da massa $(\mathrm{Hm})$ obtida das curvas de desenvolvimento da massa conforme substituição de farinha de trigo (FT) por amido resistente de milho (ARM).

\begin{tabular}{cc}
\hline ARM (\%) & $\boldsymbol{H m}(\mathbf{m m})$ \\
\hline 0,0 & $45,2 \pm 1,3$ \\
1,5 & $41,2 \pm 1,3^{\mathrm{ab}}$ \\
3,5 & $41,4 \pm 0,9^{\mathrm{b}}$ \\
8,5 & $38,1 \pm 0,5^{\mathrm{a}}$ \\
13,5 & $34,3 \pm 0,9^{\mathrm{c}}$ \\
15,5 & $32,3 \pm 1,3^{\mathrm{c}}$ \\
\hline DMS & 4,6
\end{tabular}

Médias na mesma coluna com a mesma letra não são significativamente diferentes $(p>0,05)$

DMS: diferença mínima significativa

A altura de desenvolvimento da massa não foi influenciada até a substituição de $8,5 \%$ de ARM. A partir de 8,5 \%, pode-se considerar que a diluição do glúten da massa, causada pela substituição de ARM, provocou uma redução significativa da retenção de gás produzido pelas leveduras, se comparada com as massas produzidas com quantidade inferiores de ARM.

Analisando a Figura 4-9, observa-se claramente uma tendência de queda do valor de $H$ m, e os dados foram bem ajustados a equação linear dada pela equação 4.3, em função da substituição de FT por ARM:

$$
\begin{gathered}
H m(\mathrm{~mm})=43,9-0,7 \times \mathrm{ARM} \\
\mathrm{R}^{2}=0,96 \\
0,0 \% \leq \mathrm{ARM} \leq 15,5 \%
\end{gathered}
$$




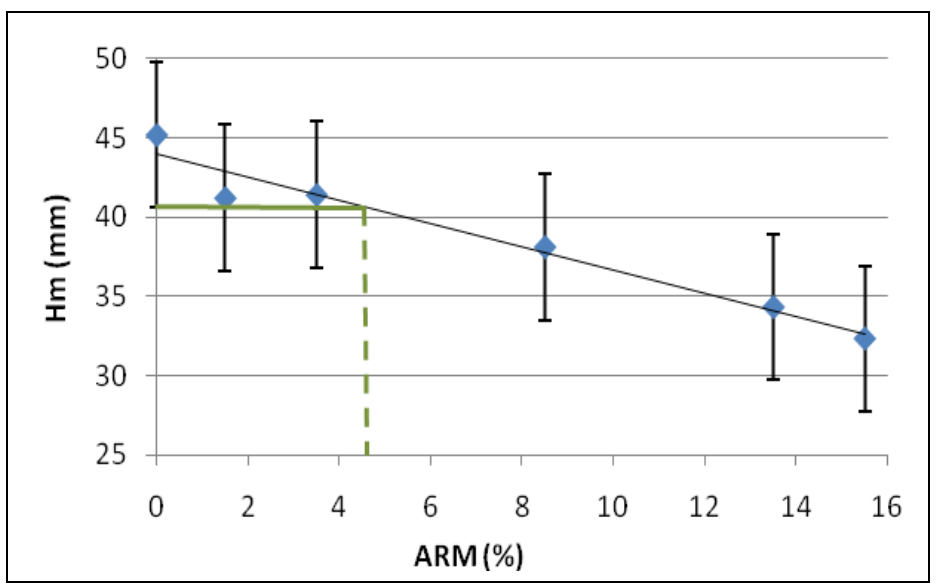

Figura 4-9. Altura de desenvolvimento da massa $(\mathrm{Hm})$ determinada no reofermentógrafo em função do nível de substituição de farinha de trigo (FT) por amido resistente de milho (ARM).

Um valor de substituição de FT por ARM que não causaria diferença de $\mathrm{Hm}$ em relação ao controle pode ser calculado utilizando o DMS, como mostrado na Figura 4-9. Para essa farinha de trigo foi $4,6 \%$.

Wang, Rosell e Barber (2002) adicionaram diferentes tipos de fibras e os parâmetros $T$ '1 e $T x$ diminuíram com o aumento destas, no entanto também não foi obtida alteração no $C_{r}$. Os autores concluíram que a adição dessas fibras modifica as propriedades reológicas de uma forma mais branda do que quando adicionado farelo às misturas.

\subsection{Glúten úmido e seco}

Os valores médios de todos os ensaios estão descritos na Tabela 4-12. Todas as amostras foram realizadas em duplicata. 
Tabela 4-12. Conteúdos de glúten úmido, glúten seco e índice de glúten das misturas conforme substituição de farinha de trigo (FT) por amido resistente de milho (ARM) e adição da enzima transglutaminase (TG).

\begin{tabular}{ccccc}
\hline ARM (\%) & TG (\%) & Glúten úmido (\%) & Glúten seco (\%) & Índice de glúten \\
\hline 3,5 & 0,05 & $26,9 \pm 0,1$ & $9,2 \pm 0,1$ & $89,2 \pm 3,0$ \\
13,5 & 0,05 & $24,9 \pm 0,6$ & $7,4 \pm 1,1$ & $89,3 \pm 4,5$ \\
3,5 & 0,15 & $29,6 \pm 0,8$ & $10,7 \pm 1,1$ & $79,3 \pm 2,9$ \\
13,5 & 0,15 & $24,9 \pm 0,4$ & $8,7 \pm 0,1$ & $98,4 \pm 0,2$ \\
8,5 & 0,10 & $26,1 \pm 0,2$ & $8,2 \pm 1,0$ & $98,6 \pm 0,8$ \\
8,5 & 0,10 & $24,9 \pm 0,3$ & $8,8 \pm 0,1$ & $92,1 \pm 1,4$ \\
8,5 & 0,10 & $25,4 \pm 0,3$ & $9,9 \pm 0,6$ & $91,3 \pm 1,0$ \\
1,5 & 0,10 & $29,0 \pm 1,5$ & $9,6 \pm 0,5$ & $93,3 \pm 3,8$ \\
8,5 & 0,17 & $25,8 \pm 0,5$ & $10,1 \pm 0,1$ & $95,9 \pm 0,3$ \\
15,5 & 0,10 & $22,9 \pm 0,1$ & $7,9 \pm 0,3$ & $93,3 \pm 0,5$ \\
8,5 & 0,03 & $26,7 \pm 0,3$ & $9,2 \pm 0,0$ & $89,4 \pm 0,7$ \\
0,0 & 0,00 & $28,7 \pm 3,9$ & $9,9 \pm 1,5$ & $92,9 \pm 2,2$ \\
\hline
\end{tabular}

ANOVA foi executada no intervalo de confiança de $95 \%$ nos parâmetros de glúten úmido, glúten seco e índice de glúten. A Figura 4-10 mostra os efeitos causados pelo ARM e a TG. Todos dos parâmetros foram influenciados apenas pela substituição de FT por ARM.

O conteúdo de glúten úmido sofreu influencia significativa dentro do intervalo entre 1,5 e 15,5 \% de substituição de FT por ARM, diminuindo com o aumento da substituição. Para a máxima substituição, houve um decréscimo de $20 \%$ em relação ao controle, resultado semelhante ao realizado por MATSUDA (2007), que para a substituição de $15 \%$ de $A R M$, houve um decréscimo no conteúdo de glúten úmido de $21 \%$ em relação ao controle.

O Índice de glúten foi influenciado pelo ARM, aumentando com o aumento da substituição.

A Tabela 4-13 mostra as diferenças causadas pelo ARM individualmente sobre os valores de glúten úmido, glúten seco e índice de glúten. Observa-se que até o nível de substituição de 3,5 \% de FT por ARM não influenciou o glúten úmido das massas. No entanto este nível é maior para o glúten seco (até $8,5 \%$ ), devido à diferença de umidade das massas. 
Tabela 4-13. Valores médios dos conteúdos de glúten úmido e seco

\begin{tabular}{cccc}
\hline ARM (\%) & Glúten úmido (\%) & Glúten seco (\%) & Índice de glúten \\
\hline 0,0 & $28,7 \pm 3,9$ & $9,9 \pm 1,5$ & $92,9 \pm 2,2$ \\
\hdashline 1,5 & $30,1 \pm 0,9^{\mathrm{a}}$ & $10,0 \pm 0,9^{\mathrm{ab}} \mathrm{c}^{-\cdots}$ & $90,6 \pm 4,6^{\mathrm{ab}} \cdots \ldots$ \\
3,5 & $28,3 \pm 0,4^{\mathrm{a}}$ & $9,9 \pm 0,4^{\mathrm{c}}$ & $84,2 \pm 2,3^{\mathrm{a}}$ \\
8,5 & $25,8 \pm 0,3^{\mathrm{b}}$ & $9,3 \pm 0,3^{\mathrm{bc}}$ & $93,5 \pm 1,4^{\mathrm{b}}$ \\
13,5 & $24,9 \pm 0,4^{\mathrm{b}}$ & $8,1 \pm 0,4^{\mathrm{a}}$ & $93,9 \pm 2,3^{\mathrm{b}}$ \\
15,5 & $22,9 \pm 0,6^{\mathrm{c}}$ & $7,9 \pm 0,6^{\mathrm{ab}}$ & $93,4 \pm 3,2^{\mathrm{b}}$ \\
\hline DMS & 2,3 & 2,3 & 11,8
\end{tabular}

Médias na mesma coluna com a mesma letra não são significativamente diferentes $(p>0,05)$ DMS: diferença mínima significativa

Segundo Pizzinato (1997), o índice de glúten pode classificar a farinha de trigo quanto a sua qualidade, isto é > 90 a farinha é considerada muito boa; entre 60 e 90 é considerada boa. Essa mistura, portanto, mesmo com substituição máxima $(15,5 \%)$ por ARM pode ser classificada como de boa qualidade.
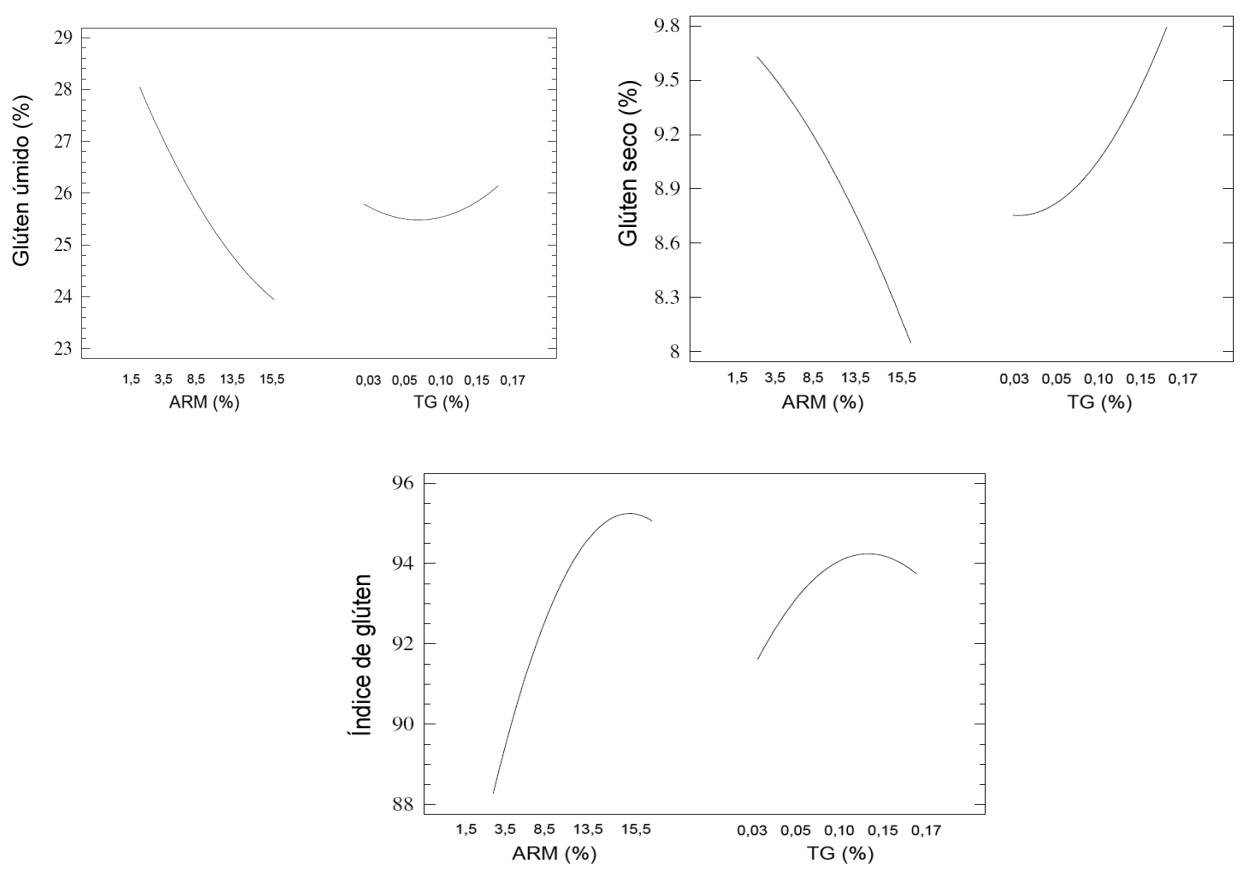

Figura 4-10. Efeitos principais causados pela substituição por amido resistente de milho (ARM) e adição da enzima transglutaminase (TG) nos parâmetros glúten úmido, glúten seco e índice de glúten. 
Considerando o limite inferior da DMS (2,3\%) obtida pela ANOVA, e o valor de glúten úmido obtido da massa com nível de substituição de 1,5 \% (30,1\%), foi possível predizer o nível de substituição de FT por ARM máximo a ser utilizado na formulação que resultaria uma massa com conteúdos de glúten úmido e seco comparáveis aos obtidos da massa controle. Em ambos os casos, o controle $(0 \%$ de substituição) apresenta valores iguais aos obtidos para o nível 1,5 \% de substituição (Figura 4-11). Da mesma forma, Matsuda (2007) determinou que o nível de substituição de $8,5 \%$ resulta em valores de glúten úmido diferentes do controle.

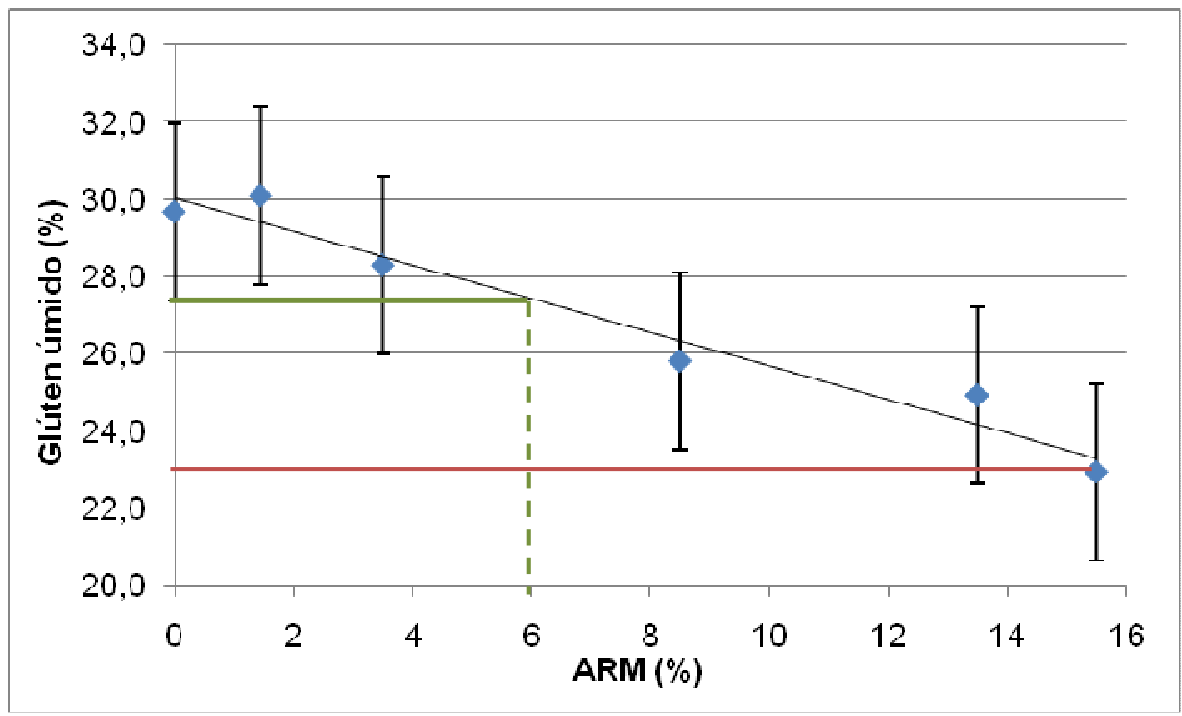

Figura 4-11. Conteúdo de glúten úmido determinado pelo Glutomatic em função da substituição de farinha de trigo (FT) por amido resistente de milho (ARM).

Dos dados apresentados na Figura 4-11, observa-se claramente uma tendência de queda do conteúdo de glúten úmido, que foram bem ajustados a equação linear 4.4, em função da substituição de FT por ARM:

$$
\begin{gathered}
\text { Glúten úmido }(\%)=30,0-0,43 \times \mathrm{ARM} \quad \text { (equação 4.4) } \\
\mathrm{R}^{2}=0,96 \\
0,0 \% \leq \mathrm{ARM} \leq 15,5 \%
\end{gathered}
$$

Segundo Pizzinatto (1997), uma farinha de qualidade média deve conter entre (23 e 30) \% de glúten úmido. Para que a mistura esteja dentro desse intervalo, pode 
ser substituída até $15,5 \%$ de FT por ARM. Por outro lado, se a FT for substituída por ARM até 6,0\%, como indicado na Figura 4-11, essa mistura é considerada igual ao controle em relação ao conteúdo de glúten úmido.

\subsection{Farinografia}

ANOVA foi executada no intervalo de confiança de 95 \% nos parâmetros obtidos do farinógrafo: absorção de água, tempo de desenvolvimento da massa $\left(t_{d}\right)$, estabilidade $(E)$ e índice de tolerância à mistura (ITM).

A TG não influenciou significativamente nenhum dos parâmetros analisados, dentro do intervalo entre $(0,03$ e 0,17$) \%$ de adição.

Os ensaios realizados mostraram que a absorção de água variou entre $(62,4$ e 65,2$)$ \% para as substituições entre $(1,5$ e 15,5) \%, sendo que o maior nível de substituição causou um aumento de 4,5 \% na absorção em relação ao controle. Os valores médios dos parâmetros absorção de água, tempo de desenvolvimento da massa $\left(t_{d}\right)$, estabilidade $(E)$ e índice de tolerância da massa (ITM) conforme substituição da FT por ARM estão apresentados na Tabela 4-14.

Tabela 4-14. Valores médios dos parâmetros obtidos das massas analisadas em farinógrafo conforme substituição de farinha de trigo (FT) por amido resistente de milho (ARM).

\begin{tabular}{ccccc}
\hline ARM (\%) & Absorção (\%) & $\boldsymbol{t}_{\boldsymbol{d}}(\%)$ & $\boldsymbol{E}(\mathbf{m i n})$ & ITM (U.F.) \\
\hline 0,0 & 62,4 & 2,0 & 4,3 & 36 \\
\hdashline $1,5^{2}$ & $62,4 \pm 0,5^{\mathrm{a}}$ & $2,4 \pm 0,2^{\mathrm{a}}$ & $3,1 \pm 0,2^{\mathrm{a}^{-}}$ & $47 \pm 4^{\mathrm{a}^{\mathrm{a}}}$ \\
3,5 & $62,6 \pm 0,4^{\mathrm{a}}$ & $1,8 \pm 0,1^{\mathrm{abc}}$ & $3,0 \pm 0,2^{\mathrm{a}}$ & $45 \pm 3^{\mathrm{a}}$ \\
8,5 & $63,6 \pm 0,2^{\mathrm{a}}$ & $1,8 \pm 0,1^{\mathrm{b}}$ & $2,0 \pm 0,1^{\mathrm{b}}$ & $65 \pm 2^{\mathrm{b}}$ \\
13,5 & $64,8 \pm 0,4^{\mathrm{b}}$ & $1,5 \pm 0,1^{\mathrm{bc}}$ & $1,8 \pm 0,2^{\mathrm{b}}$ & $69 \pm 3^{\mathrm{b}}$ \\
15,5 & $65,2 \pm 0,5^{\mathrm{b}}$ & $1,3 \pm 0,2^{\mathrm{c}}$ & $1,7 \pm 0,2^{\mathrm{b}}$ & $84 \pm 4^{\mathrm{c}}$ \\
\hline DMS & 1,8 & 0,6 & 0,8 & 13
\end{tabular}

Médias na mesma coluna com a mesma letra não são significativamente diferentes $(p>0,05)$

DMS: diferença mínima significativa

A redução do tempo de desenvolvimento evidencia o enfraquecimento da massa. Farinhas fortes normalmente têm alto teor de proteínas e são caracterizadas por elevados valores de absorção de água e de tempo de desenvolvimento da massa e baixo índice de tolerância à mistura. Pizzinatto (1997) sugere valores desejáveis de absorção de água $\geq 58$ \% e ITM de (15 a 50) U.F. 


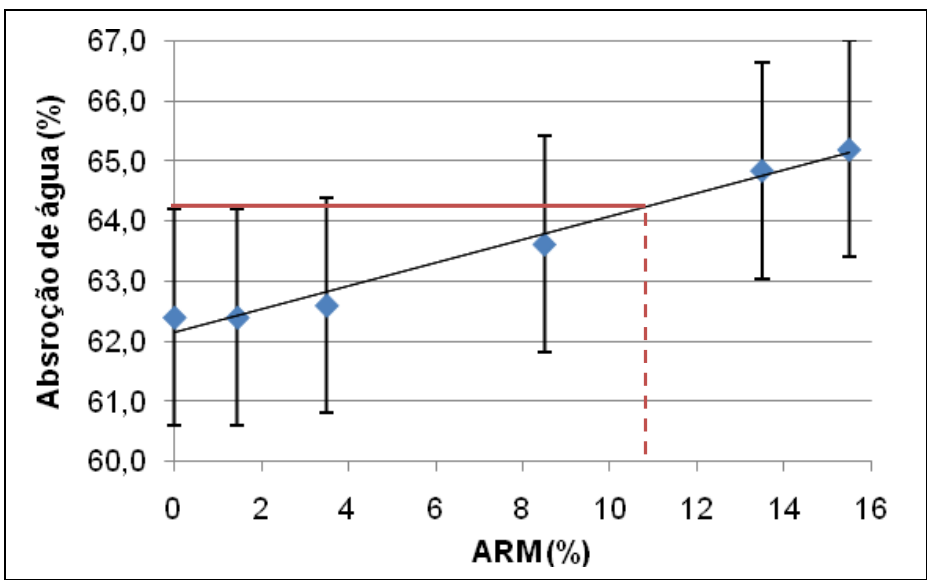

Figura 4-12. Valores médios de absorção de água determinada pelo farinógrafo Brabender para diferentes substituições de farinha de trigo (FT) por amido resistente de milho (ARM).

A Figura 4-12 mostra um aumento da absorção de água com o aumento de ARM, e os dados foram bem ajustados a equação linear 4.5 , em função da substituição de FT por ARM:

$$
\begin{gathered}
\text { Absorção }(\%)=62,1+0,19 \times \mathrm{ARM} \quad \text { (equação 4.5) } \\
\mathrm{R}^{2}=0,98 \\
0,0 \% \leq \mathrm{ARM} \leq 15,5 \%
\end{gathered}
$$

Aplicando essa equação, é possível calcular a quantidade máxima de substituição de FT por ARM para que a mistura tenha uma absorção igual ao controle $(62,4 \pm 1,8) \%$. Esse valor é $11 \%$ de ARM.

\subsection{Umidade e cinzas das massas}

Os valores médios dos teores de umidade e cinzas das massas, que foram realizados em quadruplicata, estão apresentados na Tabela 4-15. 
Tabela 4-15. Valores médios em base úmida dos teores de umidade e cinzas das massas analisadas conforme substituição de farinha de trigo (FT) por amido resistente de milho (ARM) e adição da enzima transglutaminase (TG).

\begin{tabular}{cccc}
\hline ARM (\%) & TG (\%) & Umidade (\%) & Cinzas (\%) \\
\hline 3,5 & 0,05 & $44,92 \pm 0,09$ & $1,58 \pm 0,01$ \\
13,5 & 0,05 & $44,57 \pm 0,09$ & $1,48 \pm 0,03$ \\
3,5 & 0,15 & $40,54 \pm 0,15$ & $1,61 \pm 0,02$ \\
13,5 & 0,15 & $46,05 \pm 2,42$ & $1,56 \pm 0,02$ \\
8,5 & 0,10 & $44,84 \pm 0,07$ & $1,57 \pm 0,03$ \\
8,5 & 0,10 & $44,81 \pm 0,09$ & $1,49 \pm 0,02$ \\
8,5 & 0,10 & $44,89 \pm 0,08$ & $1,55 \pm 0,00$ \\
1,5 & 0,10 & $44,92 \pm 0,09$ & $1,59 \pm 0,01$ \\
8,5 & 0,17 & $45,05 \pm 0,05$ & $1,59 \pm 0,00$ \\
15,5 & 0,10 & $44,18 \pm 0,08$ & $1,45 \pm 0,02$ \\
8,5 & 0,03 & $44,75 \pm 0,17$ & $1,56 \pm 0,01$ \\
0,0 & 0,00 & $43,78 \pm 0,16$ & $1,58 \pm 0,03$ \\
\hline
\end{tabular}

ANOVA foi executada no intervalo de confiança de $95 \%$ nos parâmetros de umidade e cinzas. Os efeitos dos parâmetros foram avaliados individualmente, apesar de que todas as formulações foram preparadas conjuntamente com ARM e TG, conforme apresentado no planejamento experimental.

Verificou-se que a umidade apresentou alteração significativa $(p<0,05)$ quando a FT foi substituída pelo ARM. Já o teor de cinzas apresentou alteração tanto na substituição de FT por ARM como pela adição de TG, com efeitos contrários (Figura 4-13).

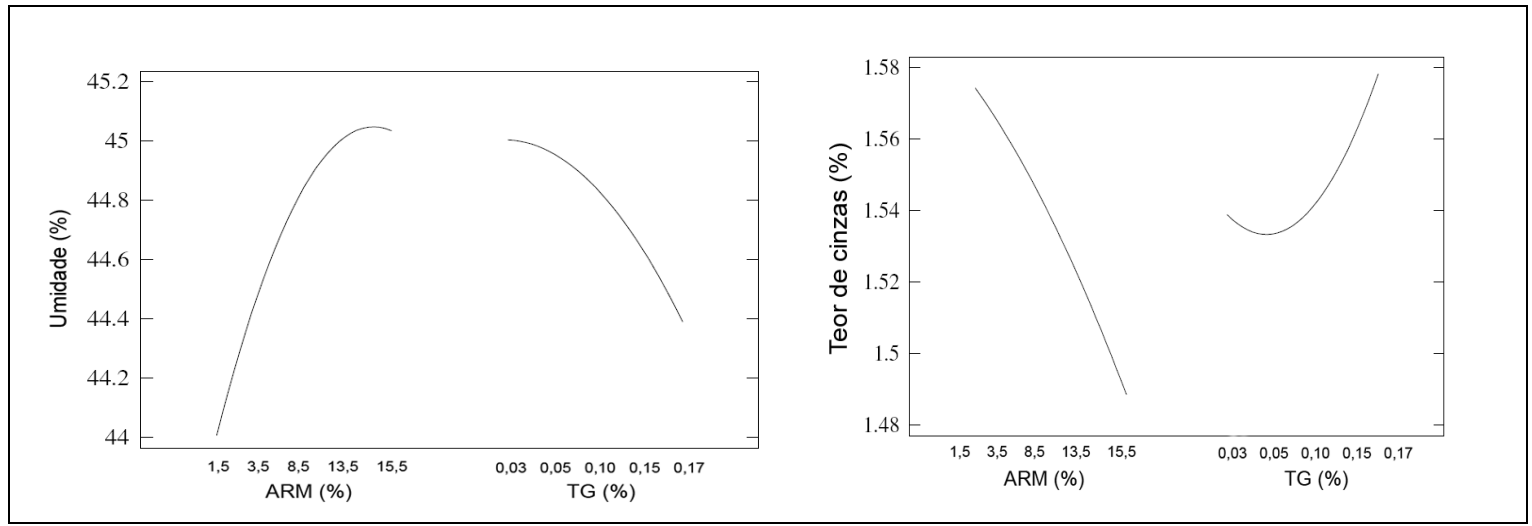

Figura 4-13. Efeitos principais causado pela substituição de FT por ARM e adição de TG no teor de umidade e cinzas das massas. 
Conforme o aumento da substituição de FT por ARM, o teor de cinzas diminuiu e a umidade aumentou, e com a adição de TG, o teor de cinzas aumentou. A Tabela 4-16 apresenta os valores médios das cinzas e umidade de acordo com o nível de substituição de FT por ARM e a Tabela 4-17 os valores médios de cinzas para os níveis de adição de TG.

Tabela 4-16. Valores médios obtidos para a umidade das massas e cinzas conforme substituição de farinha de trigo (FT) por amido resistente de milho (ARM).

\begin{tabular}{ccc}
\hline ARM (\%) & Umidade (\%) & Cinzas (\%) \\
\hline 0,0 & $43,8 \pm 0,2$ & $1,58 \pm 0,03$ \\
1,5 & $44,9 \pm 0,6^{\mathrm{a}}$ & $1,59 \pm 0,02^{\mathrm{ab}}$ \\
3,5 & $42,7 \pm 0,4^{\mathrm{b}}$ & $1,59 \pm 0,01^{\mathrm{a}}$ \\
8,5 & $44,9 \pm 0,3^{\mathrm{a}}$ & $1,55 \pm 0,01^{\mathrm{b}}$ \\
13,5 & $45,3 \pm 0,4^{\mathrm{a}}$ & $1,52 \pm 0,01^{\mathrm{c}}$ \\
15,5 & $44,2 \pm 0,6^{\mathrm{ab}}$ & $1,45 \pm 0,02^{\mathrm{d}}$ \\
\hline DMS & 1,8 & 0,05
\end{tabular}

Médias na mesma coluna com a mesma letra não são significativamente diferentes $(p>0,05)$ DMS: diferença mínima significativa

Tabela 4-17. Valores médios obtidos para as cinzas

\begin{tabular}{cc}
\hline TG (\%) & Cinzas (\%) \\
\hline 0,00 & $1,58 \pm 0,03$ \\
0,03 & $1,56 \pm 0,02^{\mathrm{a} \mathrm{b}^{-}}$ \\
0,05 & $1,53 \pm 0,02^{\mathrm{a}}$ \\
0,10 & $1,53 \pm 0,01^{\mathrm{a}}$ \\
0,15 & $1,58 \pm 0,02^{\mathrm{b}}$ \\
0,17 & $1,59 \pm 0,02^{\mathrm{b}}$ \\
\hline DMS & 0,07
\end{tabular}

Médias na mesma coluna com a mesma letra não são significativamente diferentes $(p>0,05)$

DMS: diferença mínima significativa

O modelo preditivo obtido através de regressão para as cinzas da massa de pão em função da quantidade de ARM e TG é dado por:

$$
\begin{gathered}
\text { Cinzas }(\%)=\left(1,68-0,01 \times \text { ARM }-1,74 \times \mathrm{TG}+8.22 \times \mathrm{TG}^{2}\right) \pm 0,02 \\
\mathrm{R}^{2}=0,77 \\
1,5 \% \leq \mathrm{ARM} \leq 15,5 \% \quad 0,03 \% \leq \mathrm{TG} \leq 0,17 \%
\end{gathered}
$$




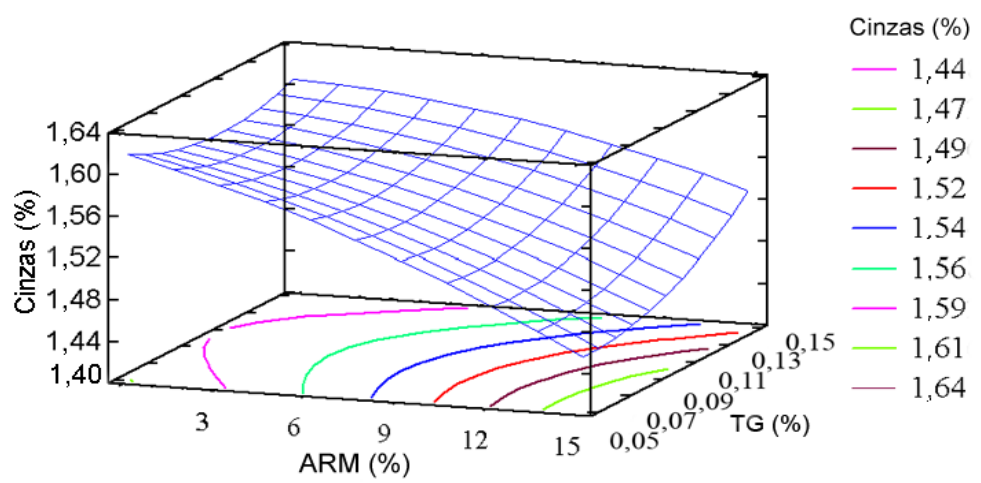

Figura 4-14. Superfície de resposta para o conteúdo de cinzas conforme substituição de farinha de trigo (FT) por amido resistente de milho (ARM) e adição da enzima transglutaminase (TG).

A adição de TG causou pouca influência sobre os parâmetros reológicos (reofermentógrafo, farinógrafo), térmicos (DSC) e físicos (umidade, cinzas), da mesma forma que os resultados obtidos na análise de textura. Por não ser considerado um ingrediente natural em massa de pão e possuir um custo elevado quando comparado com enzimas tradicionalmente utilizadas, como a alfa-amilase, mais estudos utilizando essa enzima devem ser criteriosamente conduzidos.

Em muitos ensaios foi possível observar que acima de 8,5 \% de substituição, ocorreu um decréscimo da qualidade das massas em relação ao controle. Estimou-se com base em todos os ensaios realizados nas massas de pão, que um valor adequado de substituição de FT por ARM para essa mistura seria até 8,5 \%. Desta forma, as propriedades não seriam drasticamente alteradas, obtendo pão com estrutura e volume semelhantes ao pão tradicional, porém com a vantagem de possuir uma maior quantidade de fibras. 


\section{CONCLUSÕES}

Nos ensaios de textura das massas produzidas com substituição de farinha de trigo (FT) por amido resistente de milho (ARM) de $(1,5-15,5) \%$ base mistura, e adição de transglutaminase (TG) de $(0,03$ - 0,17) \% base mistura, pode-se concluir:

- A substituição de FT por ARM causou um aumento da resistência à extensão da massa até $8,5 \%$, e logo após um decréscimo devido ao enfraquecimento do glúten; o comportamento inverso foi obtido para a extensibilidade $(L)$, em teste de extensão uniaxial.

- O aumento das porcentagens de substituição de FT por ARM causaram um aumento na tenacidade $(P)$ e um decréscimo na extensibilidade $(L)$ e consequente aumento na razão $P / L$ no teste de extensão biaxial. Até 8,5\% de substituição de FT por ARM esses parâmetros não são significativamente alterados.

- A dureza e resiliência da massa aumentaram significativamente com a substituição de FT por ARM, acima de 3,5\%. A coesividade, adesividade e elasticidade não foram influenciadas pela substituição de FT por ARM e nem pela adição de TG, podendo ser trabalhadas nesse intervalo sem causarem diferenças no desempenho da massa.

- Nos ensaios realizados em DSC foi possível identificar três picos endotérmicos, sendo eles: fusão da água $\left(0^{\circ} \mathrm{C}\right)$, gelatinização do amido do trigo $\left(60^{\circ} \mathrm{C}\right)$ e gelatinização do $\operatorname{ARM}\left(110^{\circ} \mathrm{C}\right)$. O pico de fusão da água e de gelatinização do amido de trigo não apresentaram diferença significativa quando substituída a FT por ARM, e a adição de TG. A quantidade de água adicionada no preparo das massas foi a mesma e o ARM não influenciou na quantidade de água congelável.

- Nos ensaios do reofermentógrafo, foi observado o comportamento esperado para a altura máxima de desenvolvimento $(H m)$, já que reduzindo a quantidade de glúten da massa, presente na FT, sua estrutura foi prejudicada. Durante a fermentação da massa, a substituição de FT por ARM em quantidade maiores que $8,5 \%$ reduziu a capacidade de desenvolvimento da massa, não atingindo a mesma altura em relação a da massa produzida somente com FT. De qualquer forma, com a substituição de FT por ARM até 15,5 \%, o coeficiente de 
retenção do gás $\left(C_{r}\right)$ não foi influenciado, indicando que a redução da altura da massa não reflete no aumento da porosidade e conseqüente perda de gás.

- O conteúdo de glúten úmido sofreu influência significativa com a substituição de FT por ARM, diminuindo com o aumento da substituição. Para que este parâmetro seja considerado igual ao controle, a FT pode ser substituída por ARM até 6,0\%. Pelo índice de glúten, mesmo essa FT sendo substituída por ARM no nível máximo (15,5\%), pode ser classificada como de boa qualidade.

- O maior nível de substituição de FT por ARM causou um aumento de 4,5\% na absorção de água em relação ao controle, determinada pelo farinógrafo. Utilizando a equação linear da absorção com a substituição do ARM, calculou-se que $11 \%$ de substituição de FT por ARM nessa mistura obterá a absorção semelhante ao controle. A TG não influenciou nenhum dos parâmetros da farinografia.

- O aumento do conteúdo de umidade das misturas pode ser devido à maior absorção de água do ambiente pelo ARM, que contém $40 \%$ de amido comum.

- A diminuição da quantidade de cinzas presentes na massa, conforme ocorreu o aumento da substituição de FT por ARM é coerente, já que as cinzas estão presentes na farinha, e não no ARM.

De uma forma geral, o uso da enzima transglutaminase (TG) não trouxe grandes benefícios para essa farinha no intervalo testado e sugere-se, portanto, apenas a adição de amido resistente de milho (ARM) em substituições até 8,5\% para que o pão torne-se um alimento funcional sem perder suas características estruturais. Desta forma, o pão poderá ser considerado um alimento funcional como fonte de fibras. 


\section{REFERÊNCIAS BIBLIOGRÁFICAS ${ }^{7}$}

AACC (American Association of Cereal Chemists). AACC report: the definition of dietary fiber. Cereal Foods World, v. 46, p. 112-129, 2001.

AACC (American Association of Cereal Chemists). Approved methods of the AACC. 9a ed. St. Paul, Minnesota: The Association, 1995.

ÅKERBERG, A., LILJEBERG, H., BJÖRCK, I. Effect of amylose/amylopectin ratio and baking conditions on resistant starch formation and glycaemic indices. Journal of Cereal Science, v. 28, p. 71-80, 1998.

AÑÓN, M. C., LE BAIL, A., LEON, A. E. Effect of Freezing on Dough Ingredients. In: HUI, Y. H., CORNILLON, P., LEGARETTA, I. G., LIM, M. H., MURREL, K. D., NIP, W-K. Handbook of Frozen Foods. New York: Marcel Dekker, Inc., 2004, p. 571-580. S1, 1992.

ASP, N. G. Preface: Resistant Starch. European Journal of Clinical Nutrition, v. 46, p.

BASMAN, A; KÖKSEL, H.; NG, P. K. W. Effects of increasing levels of transglutaminase on the rheological properties and bread quality characteristics of two wheat flours. European Food Research Technology, v. 215, p. 419-424, 2002.

BENASSI, V. T., WATANABE, E., LOBO, A. R. Produtos de panificação com conteúdo calórico reduzido. Boletim do Centro de Pesquisa e Processamento de Alimentos, Curitiba, v. 19, p. 225-242, 2001.

BERRY, C. S. Resistant Starch: formation and measurement of starch that survives exhaustive digestion with amylolitic enzymes during the determination of dietary fibre. Journal of Cereal Science, v. 4, p. 301-314, 1986.

BRASIL. Agência Nacional de Vigilância Sanitária (ANVISA). Aprova o regulamento técnico que estabelece as diretrizes básicas para análise e comprovação de propriedades funcionais e/ou de saúde alegadas em rotulagem de alimentos. Portaria no 398 , de 30 abril de 1999. D.O.U. - Diário Oficial da União, Brasília, 1999. Disponível em: $<$ http://elegis.anvisa.gov.br/leisref/public/showAct.php?id=11297\&word=>. Acesso em: 12 mai. 2008.

BRASIL. ANVISA - Agência Nacional de Vigilância Sanitária. Aprova o Regulamento Técnico: Aditivos Alimentares - definições, classificação e emprego. Portaria no 540 , de 27 de outubro de 1997. D.O.U. - Diário Oficial da União; Brasília, 1997. Disponível em: <http://elegis.anvisa.gov.br/leisref/public/showAct.php>. Acesso em: 9 abr. 2008.

BRASIL. ANVISA - Agência Nacional de Vigilância Sanitária. Aprova o Regulamento Técnico referente a Alimentos para Fins Especiais. Portaria no 29, de 13 de janeiro de 1998. D.O.U. - Diário Oficial da União; Brasília, 1998a. Disponível em: <http://elegis.anvisa.gov.br/leisref/public/showAct.php?id=17213\&word= >. Acesso em: 9 abr. 2008.

\footnotetext{
${ }^{7}$ Baseado na Norma ABNT NBR 6023 (2002) com as devidas adaptações à literatura da área da engenharia.
} 
BRASIL. ANVISA - Agência Nacional de Vigilância Sanitária. Aprova o Regulamento Técnico referente à Informação Nutricional Complementar (declarações relacionadas ao conteúdo de nutrientes), constantes do anexo desta Portaria. Portaria no 27, de 13 de janeiro de 1998. D.O.U. - Diário Oficial da União; Brasília, 1998b. Disponível em: <http://elegis.anvisa.gov.br/leisref/public/showAct.php?id=97>. Acesso em: 9 abr. 2008.

BRASIL. ANVISA - Agência Nacional de Vigilância Sanitária. Aprova o "Regulamento técnico que aprova o uso de Aditivos Alimentares, estabelecendo sua Funções e seus Limites Máximos para a Categoria de Alimentos 7- Produtos de Panificação e Biscoitos". Resolução no 383, de 05 de agosto de 1999. D.O.U. - Diário Oficial da União, Brasília, 1999. Disponível em: < http://e-legis.anvisa.gov.br/leisref/public/showAct.php?id=117>. Acesso em: 08 mar. 2008.

BROUNS, F. Soya isoflavones: a new and promissing ingredient for the health food sector. Food Research International, v. 35, p. 187-193, 2002.

BURTON, P.; LIGHTOWLER, H.J.. The impact of freezing and toasting on the glycaemic response of white bread. European Journal of Clinical Nutrition, v. 62, p. 594-599, 2008.

CAUVAIN, P.; YOUNG, L.S. Technology of Breadmaking. USA: Aspen Publishers, 1999. 354p.

CHAMP, M. Determination of resistant starch in food products: interlaboratory study. European Journal of Clinical Nutrition, v. 46, p. 51-52, 1992.

COLLAR, C.; BOLLÁIN, C. Impact of microbial transglutaminase on the viscoelastic profile of formulated bread doughs. European Food Research Technology, v. 218, p. 139-146, 2004.

DHINGRA, S., JOOD, S. Organoleptic and nutritional evaluation of wheat breads supplemented with soybean and barley flour. Food Chemistry, v. 77, p. 479-488, 2001.

DOG, T. L. Menopause: a review of botanical dietary supplements. The American Journal of Medicine, v. 118, p. 98S-108S, 2005.

EERLINGEN, R. C., DELCOUR, J. A. Formation, analysis, structure and properties of type III enzyme resistant starch. Journal of Cereal Science, v. 22, p. 129-38, 1995.

ENGLYST, H. N., WIGGINS, H. S., CUMMINGS, J. H. Determination of the non-starch polysaccharides in plant foods by gas-liquid chromatography of constituent sugars as alditol acetates. Analyst, v. 107, p. 307-318, 1982.

FAISANT, N., PLANCHOT, V., KOZIWSKI, F., COLONNA, P., CHAMP, M. Resistant starch determination adapted to products containing high level of resistant starch. Science des Aliments, v. 15, p. 85-91, 1995.

GOESAERT, H., BRIJS, K., VERAVERBEKE, W. S., COURTIN, C. M., GEBRUERS, K., DELCOUR, J. A. Wheat flour constituents: how they impact bread quality, and how to impact their functionality. Trends in Food Science and Technology, v. 16, p. 12-30, 2005.

GOLDRING, J. M. Resistant starch: Safe intakes and legal status. Journal of AOAC International, v. 87, p. 733-739, 2004.

GOÑI, I., GARCÍA-ALONSO, A., SAURA-CALIXTO, F. A starch hydrolysis procedure to estimate glycemic index. Nutrition Research, v. 17, p. 427-437, 1997. 
GOÑI, I., GARCÍA-DIZ, I., MAÑAS, E., SAURA-CALIXTO, F. Analysis of resistant starch: a method for foods and food products. Food Chemistry, v. 56, p. 445-449, 1996.

GUJRAL, H. S., ROSELL, C. M. Functionality of rice flour modified with a microbial transglutaminase. J. of Cereal Science, v. 39, p. 225-230, 2004.

HARADA, O., LYSENKO, E. D., PRESTON, K. R. Effects of commercial hydrolitic enzyme additives on Canadian short process bread properties and processing characteristics. Cereal Chemistry, v.77, p. 70-76, 2000.

HOLM, J., BJÖRCK, I., DREWS, A., ASP, N.-G. A rapid method for the analysis of starch. Starch/Stärke, v. 38, p. 294-297, 1986

HUNG, P. V., MORITA, N. Dough properties and bread quality of floura supplemented with cross-linked cornstarches. Food Research International, v. 37, p. 461467, 2004.

HUNG, P. V., YAMAMORI, M., MORITA, N. Formation of enzyme-resistant starch in bread as affected by high-amylose wheat flour substitutions. Cereal Chemistry, v. 82, p. 690694, 2005.

KECHICHIAN, V. Adição de ingredientes antimicrobianos em filmes biodegradáveis à base de fécula de mandioca. 2007. Dissertação (Mestrado) - Escola Politécnica, Universidade de São Paulo, SP, 2007.

LEONHARDT, G.F. Fabricação de pães. Escola de Engenharia Mauá, 1999.

LILJEBERG, H., ÅKERBERG, A., BJÖRCK, I. Resistant starch formation in bread as influenced by choice of ingredients or baking conditions. Food Chemistry, v. 56, p. 389-394, 1995.

MATSUDA, L. Y. Concentração de amido resistente em pão francês pré-assado congelado: aspectos tecnológicos. 2007. 112 p. Dissertação (mestrado) - Escola Politécnica, Universidade de São Paulo, São Paulo, 2007. Disponível em: $<$ http://www.teses.usp.br/teses/disponiveis/3/3137/tde-02062008155730/publico/Dissertacao_LucianaMatsuda_rev_20080315.pdf>. Acesso em 12 de fevereiro de 2009.

MCCLEARLY, B. V., MCNALLY, M., ROSSITER, P. Measurement of resistant starch by enzymatic digestion in starch and selected plant materials: collaborative study. Journal of AOAC International, v. 85, p. 1103-1111, 2002.

MCCLEARLY, B. V., MONAGHAN, D. A. Measurement of resistant starch. Journal of AOAC International, v. 85, p. 665-675, 2002.

MENEZES, E. W., GIUNTINI, E. B., LAJOLO, F. M. Perfil de ingestão de fibra alimentar e amido resistente pela população brasileira nas últimas três décadas. In: LAJOLO, F. M., SAURA-CALIXTO, F., PENNA, E. W., MENEZES, E. W. Fibra dietética en Iberoamérica: tecnología y salud: obtención, caracterización, efecto fisiológico y aplicación en alimentos. $1^{\underline{a}}$ ed. São Paulo: Livraria Varela, 2001. Capítulo 31, p. 433-444.

METTLER TOLEDO. Thermal Analysis: Food. Collected Application TA. s.d.

MICHNIEWICZ, J., BILIADERIS, C. G., BUSHUK, W. Effect of added pentosans on some properties of wheat bread. Food Chemistry, v. 43, p. 251-257, 1991. 
MOHAMED, A. A., RAYAS-DUARTE, P., SHOGREN, R. L., SESSA, D. J. Low carbohydrates bread: Formulation, processing and sensory quality. Food Chemistry, v.99, p. 686-692, 2006.

MOINHO PACÍFICO. Laudo de análise da farinha M. Extra-PT. Laudo de análise (AFT 08.020) referente aos resultados físico-químicos do lote M $15 \mathrm{P}$ da farinha de trigo doada pelo Moinho Pacífico. Santos, 2008. 1p.

MOORE, M. M., HEINBOCKEL, M., DOCKERY, P. ULMER, H. M., ARENDT, E. K. Network formation in gluten-free bread with application of transglutaminase. Cereal Chemistry, v. 83, p. 28-36, 2006.

MORITA, N., MAEDA, T., MIYAZAKI, M., YAMAMORI, M., MIURA, H., OHTSUKA, I. Dough and baking properties of high-amylose and waxy wheat flours. Cereal Chemistry, v. 79 , p. 491-495, 2002.

MOTOKI, M.; SEGURO, K. Transglutaminase and its use for food processing. Trends in Food Science \& Technology v. 9, p. 204-210, 1998.

NAKAMURA, M.; KURATA, T. Effects of L-ascorbic acid on the rheological properties of wheat flour dough. Cereal Chemistry, v.74, n. 5, p. 647-650, 1997.

NATIONAL STARCH. Natural Hi-maize, the 5-in-1 Fiber: 5 key health benefits in 1 easy-to-use ingredient. Material técnico fornecido pela empresa, 7p, 2005. Disponível em: <http://www.foodinnovation.com/docs/Hi-maize5-in-1FiberTSB.pdf>. Acesso em: 29 de fevereiro de 2008.

NUGENT AP: Health properties of resistant starch. British Nutrition Foundation Nutrition Bulletin (2005) 30, 27-54

PALLARÉS, M. G.; LÉON, A. L.; ROSELL, C. M. Trigo. In: LÉON, A. E.; ROSELL, C. M. De tales harinas, tales panes: granos, harinas y productos de panificación en Iberoamérica. Córdoba: Hugo Báez Editor, 2007. 480 p.

PALMA, E. J.; CICHELLO, M. S. F.; PAVANELLI, A. P. Emulsificantes em panificação. Artigo técnico ART Al001 - 06/04 Oxiteno S/A Indústria e Comércio. 2004. Disponível

em: <http://www.oxiteno.com.br/aplicacoes/mercados/doc/documento.asp?artigotecnico=1\&seg mento=0100\&idioma=PO\&r=.pdf >. Acesso em : 21 out. 2008.

PIZZINATO, A. Qualidade da farinha de trigo: conceito, fatores determinants, parâmetros de avaliação e controle. Campinas: ITAL - Instituto de Tecnologia de Alimentos, 1997.

PROPAN (associação brasileira das indústrias de panificação - programa de apoio à panificação). Perfil da panificação. 2008. Disponível em: <http://www.propan.com.br/perfilpanificacao.asp>. Acesso em: 28 ago. 2008.

QUEIROZ-MONICI, K. S., COSTA, G. E. A., SILVA, N., REIS, S. M. P. M., OLIVEIRA, A. C. Bifidogenic effect of dietary fiber and resistant starch from leguminous on the intestinal microbiota of rats. Nutrition, v. 21, p. 602-608, 2005.

RAHMAN, S. Food Properties Handbook. Boca Raton, FL : CRC Press, 1995. 500p. 
RIBOTTA, P. D., PÉREZ, G. T., LÉON, A. E., AÑÓN, M. C. Effect of emulsifier and guar gum on micro structural, rheological and baking performance on frozen bread dough. Food Hydrocolloids, v. 18, p. 305-313, 2004.

RIBOTTA, P.; LEÓN, A. AND AÑÓN, A. Effect of freezing and frozen storage on the gelatinization and retrogradation of amylopectin in dough baked in a differential scanning calorimeter. Food Research International, v. 36, p. 357-363, 2003.

ROSELL, C. M., WANG, S., AJA, S., BEAN, S., LOOKHART, G. Wheat flour proteins as affected by transglutaminase and glucose oxidase. Cereal Chemistry, v. 80, p. 52-55, 2003.

ROSIN, P. M., LAJOLO, F. M., MENEZES, E. W. Measurement and characterization of dietary starches. Journal of Food Composition and Analysis, v. 15, p. 367-377, 2002.

RUPÉREZ, P., BRAVO, L. Oligofructanos y gomas. In: LAJOLO, F. M., SAURACALIXTO, F., PENNA, E. W., MENEZES, E. W. Fibra dietética en Iberoamérica: tecnología y salud: obtención, caracterización, efecto fisiológico y aplicación en alimentos. $1^{\underline{a}}$ ed. São Paulo: Livraria Varela, 2001.Capítulo 4, p. 61-76.

SAJILATA, M. G.; SINGHAL, R. S.; KULKARNI, P. R.; Resistant starch - A review, Comprehensive Reviews in Food Science and Food Safety (2006) 5, 1-17

SALGADO, J. M., Alimentos funcionais. Sociedade Brasileira de Alimentos Funcionais. Disponível em: <http://www.sbaf.org.br/_alimentos/200506_Alimentos_Funcionais.htm>. Acesso em: 24 jan. 2008.

SCHOPMEYER, H. H. Flour. In: MATZ, S. A. Bakery - technology and engineering. Inglaterra: The Avi Publishing Company, 1960. p. 3-32.

SGARBIERI, V. C., PACHECO, M. T. B. Revisão: Alimentos Funcionais Fisiológicos. Brazilian Journal of Food Technology, v. 2, p. 7-19, 1999.

SINDIPAN (SINDICATO DAS INDÚSTRIAS DE PANIFICAÇÃO). Análise setorial do mercado de panificação: 1984-2004, 2005.2 Disponível em:<http://www.sindipan.org.br/analise/perfset.htm\#TOP>. Acesso em: 03 out. 2006.

SIVARAMAKRISHNAN, H. P., SENGE, B., CHATTOPADHYAY, P. K. Rheologycal properties of rice dough for making rice bread. Journal of Food Engineering, v. 62, p. 37-45, 2004.

SMS, Stable Micro Systems (1995). TA-XT2i application study, extensibility of dough and measure of gluten quality, Texture expert guide contents.

SPICHER, G.; BRÜMMER, J-M. Baked Goods. In: REED, G.; NAGODAWITHANA, T. W. Biotechnology - Enzymes, Biomass, Food and Feed. Weinheim: VCH, 1995. 2 ed., v.9.

STAMPFLI, L.; NERSTEN, B. Emulsifiers in bread making. Food Chemistry, v. 52, p. 353-360, 1995.

STAUFFER, C. E. Principles of dough formation In: CAUVAIN, P.; YOUNG, L.S. Technology of Breadmaking. USA: Aspen Publishers, 1999. Capítulo 11, p. 262-293. 
WANG, J., ROSELL, C. M., BARBER, C. B. Effect of the addition of different fibres on wheat dough performance and bread quality. Food Chemistry v. 79, p. 221-226, 2002.

WARREN, J. M.; HENRY, C. J. K.; SIMONITE, V. Low glycemic index breakfasts and reduced food intake in preadolescent children. Pediatrics v. 112 (5), p. e414, 2003.

WASZCZYNSKYJ, N.; WILLE, G. M. F. C.; PROTZEK, E. C.; DE FREITAS, R. J. S.; PENTEADO, P. T. P. S. Tecnologia para obtenção de fibras alimentares a partir de matérias primas regionais. Experiência do Brasil. In: LAJOLO, F. M., SAURA-CALIXTO, F., PENNA, E. W., MENEZES, E. W. Fibra dietética en lberoamérica: tecnología y salud: obtención, caracterización, efecto fisiológico y aplicación en alimentos. 1aㅡ ed. São Paulo: Livraria Varela, 2001. Capítulo 16, p. 237-243.

YAMADA, Y., HOSOYA, S., NISHIMURA, S., TANAKA, T., KAJIMOTO, Y., NISHIMURA, A., KAJIMOTO, O. Effect of bread containing resistant starch on postpandrial blood glucose levels in humans. Bioscience, Biotechnology and Biochemistry, v. 69 (3), p. 559-566, 2005. 